\title{
The history of cataract surgery: from couching to phacoemulsification
}

\author{
Christopher T. Leffler ${ }^{1}$, Andrey Klebanov ${ }^{2}$, Wasim A. Samara ${ }^{1}$, Andrzej Grzybowski ${ }^{3,4}$ \\ ${ }^{1}$ Department of Ophthalmology, Virginia Commonwealth University, Richmond, VA, USA; ${ }^{2}$ Department of Indological Studies, Faculty of \\ Letters, Kyoto University, Japan; ${ }^{3}$ Department of Ophthalmology, University of Warmia and Mazury, Olsztyn, Poland; Institute for Research in \\ Ophthalmology, Poznan, Poland \\ Contributions: (I) Conception and design: CT Leffler, A Klebanov, A Grzybowski; (II) Administrative support: CT Leffler; (III) Provision of study \\ materials or patients: All authors; (IV) Collection and assembly of data: All authors; (V) Data analysis and interpretation: All authors; (VI) Manuscript \\ writing: All authors; (VII) Final approval of manuscript: All authors. \\ Correspondence to: Christopher T. Leffler, MD. Department of Ophthalmology, Virginia Commonwealth University, 401 N. 11th St., Richmond, VA \\ 23298, USA. Email: chrislefflermd@gmail.com.
}

\begin{abstract}
Where and when cataract surgery started have been a mystery. Indian tradition and the Persian author Zarrin-Dast attributed the procedure to the Indians, while pseudo-Galen suggested an Egyptian origin. Certain idiosyncratic practices are common to early Greek and Sanskrit descriptions of cataract couching, e.g., the requirement for maturity of the cataract, the preference for patients of intermediate ages, comparison of some eyes to glass, rubbing the eye, having a wide portion of the couching instrument shaft, pars-plana puncture with avoidance of the vein, and immediate vision testing. In ancient Greece and India, the words describing the color of a healthy blue eye (glaukos and nīla, respectively) could also characterize a poorly-seeing eye not curable by surgery. In both regions, the lens (or pupillary region) was compared to a lentil, and colored entoptic phenomena were noted. The sitting posture of the patient, ocular convergence towards the nose, the more systematized integration of the humoral theory with cataract surgery, and possibly blowing on the eye and putting cotton on the eye are all consistent with an Indian origin for the procedure. On the other hand, the emphasis on surgical ambidexterity could suggest an origin close to the Mediterranean. Thus, the question of where cataract surgery started has not been resolved. Various authors have suggested that multiple types of cataract surgery were practiced in the ancient and medieval periods: (I) couching, (II) discission (division), (III) aspiration through a tube, (IV) extraction through a limbal incision, and $(\mathrm{V})$ expulsion of lens remnants around an embedded probe. We review the evidence in favor (and against) each of these types of surgery.
\end{abstract}

Keywords: Medical history; cataract surgery; ophthalmology

Submitted Jan 25, 2020. Accepted for publication Aug 07, 2020.

doi: 10.21037/atm-2019-rcs-04

View this article at: http://dx.doi.org/10.21037/atm-2019-rcs-04

\section{Introduction}

We set out to review the origins of cataract surgery. Our goal was to compare compositions from the earliest cultures to describe cataract surgery to clarify when and where the procedure started, and how it evolved.

We encountered substantial variation in the literature regarding the ancient and medieval periods. Particularly with regard to the Ayurvedic (ancient Indian) literature, we saw great discrepancies between statements made in the medical literature (including ophthalmology), and the most authoritative Indology sources, in particular the encyclopedia on Sanskrit medical literature written by Gerrit Jan Meulenbeld (1928-2017) (1). For instance, the ophthalmology literature states flatly that there was a man 
named Suśruta who lived in $600 \mathrm{BCE}$, or perhaps $800 \mathrm{BCE}$, who performed cataract surgery and then wrote about it. Much of this material is just copied from earlier papers without verification from the original sources. The Indology literature tells a much more complicated tale, as we review below. The ophthalmology literature also states that Susruta performed some type of extracapsular cataract extraction by having patients forcefully exhale in order to expel lens material around the probe while it was still embedded in the eye. However, we noted from the treatise by the ophthalmic historian Julius Hirschberg that many accounts of couching during the Ayurvedic, medieval Arabic, and modern Indian periods involved the patient inhaling during or just after the procedure, rather than exhaling.

To better understand these discrepancies, we resolved to review the original source documents whenever possible. To this end, we enlisted the aid of our co-author (AK), who conducts research into Ayurvedic medicine in the ancient Sanskrit compositions at the Department of Indological Studies, Kyoto University.

With respect to other languages as well, reviewing original source documents altered the conclusions in some cases. For instance, according to the English translation of Hirschberg, which was 3 steps removed from the 1826 description of Peter Breton in Calcutta, the patient exhaled deliberately after cataract couching. However, Breton actually reported that the patient was asked to inhale forcefully (2).

We reviewed works on ophthalmology relating to the ancient Egyptian, Babylonian, Alexandrian, GrecoRoman, and Ayurvedic periods, the medieval Arabic and European periods, as well as reviews or translations relating to ophthalmology history from China, Japan, India, Tibet, Bhutan, Nepal, New Guinea, Africa, and pre-Columbian America, as cited liberally throughout our paper (3). Our goal was to determine where and how different cataract surgery techniques began.

\section{Before cataract surgery}

Over the millenia of human history, most societies have not performed cataract surgery. But they still practiced ophthalmology. Although the word surgery is derived etymologically from the word for hand, the first surgical tool was probably the mouth. Indigenous peoples of the Americas, who did not perform cataract couching, as far as anyone knows, still used the mouth as a healing tool, to suck, lick, or blow on the eye (4). Precouching societies also rubbed the eye to make it bleed to deal with ocular inflammation, corneal scars, and other conditions. Some societies operated on pterygia or superficial ocular growths by passing a thorn or hook below the opacity, lifting, and then, in some cases, cutting the opacity (4).

Precouching societies also categorized eye diseases based on the degree and extent of pupillary color or brightening $(4,5)$. Of course, the pupil of the eye should look dark, and almost any disorder which produces a lighter pupil or cornea will scatter light, and reduce vision.

\section{The origin of cataract surgery}

The ophthalmic historian Julius Hirschberg wrote: "At the present time it is impossible to answer this important historical question as to which nation (or even which man) first performed a cataract operation." (6). He also wrote "Whether the cataract operation was actually invented by the Indians can so far neither be confirmed nor denied" (6). Implicit in these statements, and in most discussions, is that cataract surgery did start in one place, and then spread throughout the world, as opposed to being independently created in multiple times and places. Indeed, we show below that there are striking and idiosyncratic similarities between the descriptions of cataract surgeries between East and West, which do tend to point to a single origin in the Old World. This contrasts with other procedures such as cranial trephination, phlebotomy, or rubbing the eyes, which seem to have been performed in diverse societies in many inhabited regions (4). These latter procedures either originated before the migration of humans to the New World, are more easily originated, or both.

\section{Late bronze age}

Some scholars have seen hints that cataract surgery might have taken place during the Bronze Age, but none of the evidence is definitive.

In India, the oldest text that has been handed down to our days is the Rgveda. It consists of more than one thousand hymns put together in ten books (7). There is some agreement concerning the relative chronology of individual books, but the absolute dating of the Rgveda remains highly contested. According to the current state of research, Rgvedic hymns were produced over a relatively short period of a few centuries before the onset of the Iron Age, that is, during the second half of the second millennium BCE (7). These compositions contain mentions 
of successful treatment of blindness with recovery of vision. For instance, RV I.112.8 relates that the divine twin brothers Aśvins "made the blind to see, the lame to go" (7). Likewise, they gave two eyes to Rjrāśva, who was blinded by his father as a punishment in RV I.116.16 and RV I.117.17, and granted eyesight to Kaṇva in RQV I.118.7 (7). Some commentators have interpreted these references as evidence of actual ophthalmic surgeries (8), but they are more likely to be meant metaphorically.

In Egypt, copper needles or probes were found in 1900 in the tomb of King Khasekhemwy at Abydos (ca. 2700 BCE) (9). Likewise, near the Saqqara pyramids close to Cairo, the tomb of Skar, one of the chief physicians in the fifth dynasty (ca. 2200 BCE), was found in 2001 to include several bronze surgical needles (9). Because rods or probes can be used for application of kohl or ointment, removal of foreign bodies, scraping the eye, nonophthalmic uses, and even nonmedical uses, the significance of these rods is unknown. In Egypt in the Old Kingdom, seven ophthalmic specialists are known. This total constitutes one third of all known specialists (10). The Ebers papyrus, the EdwinSmith papyrus, and other medical papyri of the period speak of medical recipes for ophthalmic conditions, but none refers to cataract surgery (10). A scene from the Tomb of Ipwy (or Ipuy) (ca. 1200 BCE) shows a worker at a construction site continuing to work while someone (possibly a doctor) approaches his eye with a rod $(10,11)$. As someone above the worker is chiseling, it is possible that the doctor is trying to remove an ocular foreign body which had fallen into the eye (10). Others have suggested the application of eye ointment or paint (kohl) (10). None of the mummies which have been studied have any surgical incisions anywhere on the body (10). We have some stories about the personal lives of the royal families, but are not told of any cataract surgeries.

In Babylon, the code of Hammurabi (reign 1792-1750 BCE) specified the charges and penalties for making an incision which heals a man's eye:

"If a physician [asû]...opened a man's temple with a bronze scalpel and healed the man's eye, he shall charge 10 shekels of silver (as his fee)... If an asû-physician has... opened a man's temple with a bronze scalpel and blinded the man's eye, they shall cut off his hand... If he opened his (the commoner's slave's) temple with a bronze scalpel and blinded his eye, he shall weigh out silver equal to half his value." (12).

The translator noted that although many have claimed that the code describes cataract surgery, in fact, "the procedure described cannot be verified by evidence from the medical corpus itself." (12) As translated, the procedure sounds like phlebotomy of a temporal blood vessel.

\section{The Indus and Nile Rivers in Classical Antiquity}

Just before the Common Era, we have stronger evidence of cataract surgery along the Indus and Nile Rivers. One mystery is why such disparate regions would begin to reveal clues about cataract surgery without surviving evidence from intermediate regions. Modern studies on the spread of cataract surgery to the New World can provide some understanding $(4,13,14)$. Cataract surgery simply spreads by individual surgeons who migrate, and can then hit a tipping point where it becomes established in the new region. It is possible for the procedure to "leapfrog" over areas of low population density, or which are not receptive for other reasons.

Regions close to the Indus and Nile rivers were connected politically first during the Persian empire, and later with the conquests of Alexander the Great. It is not clear which region would have been first to do the surgery. We review each region in turn.

\section{Evidence of Couching in Ancient India}

Meulenbeld summarized traditions regarding early medicine in India:

"Kāśī is sometimes depicted as an ancient centre of medical learning, in particular surgery. A.F.R. Hoernle [an early Indologist] emphasized that at least the origin of ophthalmic surgery is placed by Indian tradition in Eastern India, in Bihar, being credited to Nimi, lord of Videha. Buddhist literature, on the other hand, does not picture Kāśî as a centre of instruction in surgical skills, but mentions, instead, Takṣaśilā [Taxila]" (1).

The physician known in the Pālī cannon as Jīvaka Komārabhacca and celebrated as the "Medicine King" in Chinese Buddhist literature (15) reputedly studied in Taksaśilā under some Ātreya, possibly the same semilegendary figure, "whose teachings formed the basis of the Carakasambitā" (16).

Indeed, Takṣaśîlā, called Taxilla by the Greeks, was an important center of learning during and after the time of the Buddha and, according to Chinese sources, had a reputation for ophthalmic cures. This literature records, for example, that Ghoșa, a monk from Takșaśilā, was asked to travel to China to heal a blind prince who had heard of the 


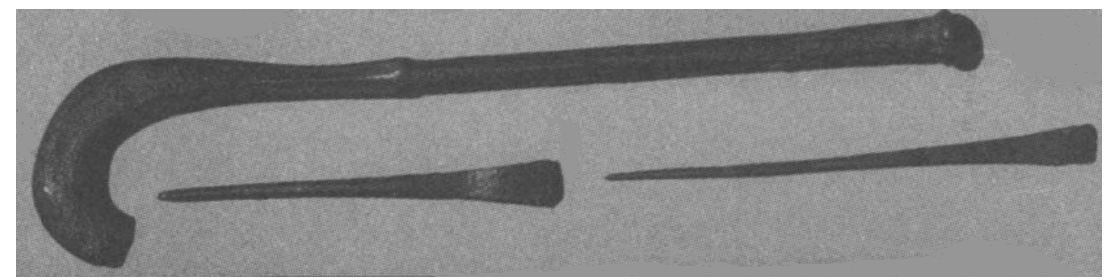

Figure 1 Copper instruments from Taxila. Presumed "decapitator" for fetal extraction, and fine probes $6.9 \mathrm{~cm}$ and $8.4 \mathrm{~cm}$ in length.

monk from travelers. The monk brought the prince to sight by bathing his eyes with tears shed by those who heard his religious instruction (Tt 2017:7, tr. Huber, Sūtrālamikāra 213f) (17). The Chinese Buddhist monk Faxian (or Fahsien, 337-ca. 422) travelled throughout central and southeast Asia, as well as India, and also wrote about Taxila. His writings include the translation of an ophthalmic sutra (T1380) (17).

The Taxila Museum contains three copper surgical probes, two of which are thin enough to perform fine work, and are thought to be general-purpose probes (Figure 1) (18). They do not look very similar to Roman couching needles, but their form in practice could have been modified. For instance, they could have had a wooden handle (18), or been wrapped with a thread to prevent excessive entry into the eye. Scholars have not commented on whether these probes were for cataract surgery (18). At a minimum, the probes provide an example of ancient Indian metallurgy. The probes have not been dated, but presumably preceded Taxila's decline in the $5^{\text {th }}$ century.

Buddhist tradition frequently compares the restoration of eyesight by a doctor with a metal instrument to the imparting of wisdom to a person blinded with ignorance by the teachings of the Buddha (17). According to the Ratnamegha-sūtra (T 660:2:289a): "By analogy, a physician who excels in therapeutics by needles (śalāka in Sanskrit) cannot operate upon the cataracts of the blind if he becomes blind himself. So the bodhisattva whose mind is blinded by ignorance cannot cut through the veil of worldliness with the needle of ignorance." (17).

A commentary from $509 \mathrm{CE}$ on the Mahäparinirvānasutra (Ttt 1763:23:469a) mentions ophthalmology using a term that corresponds with the Sanskrit śâlākya, and would include surgery with the needle, on the eyes or ears (17).

The earliest Indian text that describes cataract surgery is entitled the Suśrutasambitā. It begins by recounting that several students, among whom is Suśruta, gather around Kāśirāja (King of Varanasi) Divodāsa Dhanvantari and ask him questions about medicine. His answers are recorded in form of the Suśrutasaṃbitā (19).

It is safe to say that Indian tradition holds that ophthalmology was invented within India. At the very beginning of the Uttaratantra (SS 6.1.5), which is the section of the Suśrutasambitā describing, among other things, cataract surgery, Suśruta says that ophthalmology was taught by the King of Videha and others. According to the medieval commentator Dalhana, the King of Videha is called Nimi and "others" should refer to authorities such Karāla, Bhadraśaunaka etc. (20). The origination legend of Āyurveda, summarized at the very beginning of the Suśrutasambitā and elaborated in other medical classics, relates that the system was passed down from the Gods to human sages (such as Divodāsa Dhanvantari), who, in their turn, disseminated it among humans.

As is the case of many ancient texts in Sanskrit, neither the author of the Suśrutasambitā nor the exact date of its composition can be established with certainity. In the most extensive survey of the question, Meulenbeld writes that nothwithstanding many disagreements most scholars admit that the text consists of at least two historical layers: some "postulate two Suśrutas and [...] isolate elements belonging to an older and a yonger stratum [...] some disintguish a third one, attributed to a reviser who is called Nāgārjuna by Dalhana [fl. ca. 12th century]. Others [...] assume [...] two strata, ascribed to Suśruta and the revisor. A few scholars assume a succession of four layers [...]" (1). According to Wujastyk:

"The upshot [...] is that in Suśruta's text we have a work the kernel of which probably started some centuries BC in the form of a text mainly on surgery, but which was then heavily revised and added to in the centuries before $\mathrm{AD}$ 500." (21).

In fact, the recent discovery of an old palm-leaf manuscript of the Suśrutasaṃhitā in Nepal verifiably dated to $878 \mathrm{CE}(22-25)$, and several recent copies of previously unpublished medieval commentaries to the text 


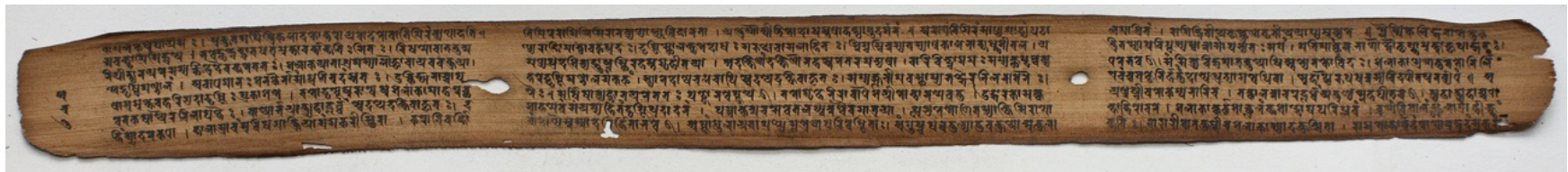

Figure 2 Description of cataract surgery from the Nepalese version of the Suśrutasaṃhitā of 878 CE: folio 167v (v = verso) of manuscript KL 699. Starting from the end of the first line are verses corresponding with SS Ut $17.55 \mathrm{ff}$ in the vulgate edition. The authors thank the NGMCP (Hamburg, Germany) and the National Archives, Kathmandu, Nepal, for providing access to digital images of the manuscript.

corroborate the above assumption that the work must have been compiled in its present form by the middle of the first millenium CE. However, these findings also demostrate that the process of revision and editing of individual readings of the Suśrutasamphitā continued well into the second millenium CE (26).

As for the reception of the Suśrutasambitā outside of India, we are informed that the work was known in some form during the rule of Hārūn al-Rashīd (766-809 CE), when it was translated by an Indian physician named Manka into Persian or Arabic at the request of the Barmakid Yahyā ibn Knhālid (1). Unfortunately, the actual translation seems not to have lasted into the modern period, so that we cannot ascertain the extent of the translated text. A medical man named Suśruta was alluded to by the Khmer king Yaśovarman I (889 to $900 \mathrm{CE}$ ) as well as in Tibetan literature (1).

It is often stated that the ophthalmic portions of medieval Arabic treatises can be attributed to Suśruta and other Indian authors, such as Vāgbhața I and II. However, when we look for hard proof, we come up empty-handed. The Paradise of Wisdom (Firdaws al-Hikma), composed by the $9^{\text {th }}$ century Persian physician `Alī ibn Sahl (Rabban) alTabarī, cited both Suśruta and Vāgbhața (1). The Paradise of Wisdom mentioned cataract $(m \hat{a})$, but not its surgical cure (27).

The Kitāb al-ḥa $\bar{w} \bar{i}$, or Comprehensive Book, known later as the Continens, of al-Rāzī (Rhazes) is a vast encyclopedia drawn primary from Greek sources, plus a few Syriac and Perisan sources. A small percentage of the Continens comes from Sanskrit sources, including Suśruta and Vāgbhața $(1,28)$. However, the Indian material in the Continens does not include cataract surgery (28). Here the absence cannot be explained away as a lack of interest in the procedure on the part of Rhazes. He did cover the cataract operations in the Greek text of Antyllus, from the 2nd century, and that in the Syriac text of Semon, perhaps from the 9th century (28).
Most authors in Arabic who discussed cataract surgery, such as Hunain Ibn Ishaq (809-877 CE) and Ali ibn Isa el-Kahhal (c. 940-1010 CE), both of Bagdad, and `Ammar ibn `Ali alMawsili of Cairo (fl. c. 1000 CE), cited the Greek authors many times, but did not cite the Indian authors explicitly. Nonetheless, as discussed below, we do find features in the descriptions of cataract surgery which suggest some relation between the Arabic and Indian literature.

In this context regarding uncertainties in dating the section of the Suśrutasambitā on cataract surgery, the above-noted discovery in 2007 of a palm leaf manuscript of the Suśrutasambitā from $878 \mathrm{CE}$ in Nepal, held at the Kaiser Shamsher library (KL) in Kathmandu, becomes more important (Manuscript KL 699) (22-25). The publications describing the manuscript have not specified whether it contains the portion on cataract surgery (22-25). However, we can confirm that this 9th century manuscript of the Suśrutasambitā (as well as the 16th century Nepalese manuscript that attests to the same recension of the text) does, in fact, describe cataract surgery (Figure 2). The Nepalese version describes the material of the medical instrument (copper or, perhaps, iron), preliminary unctioning and sudation of the patient, and having the patient look at the tip of the nose. Then, one needs to press the white portions of the eye on the sides of the pupil, puncture the "natural hole" with the copper barley-tipped instrument (using the right hand for the left eye and viceversa). If all goes well, one sees a drop of fluid and hears a characteristic sound. Thus, the 9th century Nepalese text agrees with later texts based on manuscripts which had been copied many times, and were available in 19th century India.

The next two Indian texts, the Aștāngasamgraba (AS) and the Asțāngahrdayasambitāa (AHS), have been attributed to an author or, more likely, two authors named Vāgbhata I and II, respectively. While most scholars agree upon the given relative chronology of the texts (1), the absolute dating of these works remains contested. When accepting 
that the Mādhavanidāna, an important medical work that, among other texts, draws upon both the AS and the AHS, was composed in the eighth century (29), it appears likely that Vāgbhața I and II were active, perhaps with a short gap, sometime during the period from the sixth to early eighth centuries CE. The Asțāngahrdayasambitā was referred to by Alī ibn Sahl al-Tabarī in 849/850 CE and translated into Tibetan, along with its two early commentaries, between 1013 and 1055 CE (1).

\section{Ptolemaic and early Roman Egypt}

Egypt also bears marks of ophthalmic progress just before the Common Era. According to Herodotus, the Persian king Cyrus asked the Pharaoh Amasis to send him an Egyptian oculist (30). It is interesting that Cyrus would turn to Egypt, instead of Taxila. The Persian empire abutted both Egypt, and Taxila. Perhaps, the Egyptian oculists were experts in trachoma or the application of kohl, which related to the particular disorder relevant to Cyrus. Perhaps, Cyrus had political reasons for approaching Egypt. Taxila is said to have come under the rule of Cyrus and subsequent Persian kings (18). The Persians captured Egypt in 525 BCE (31,32). This political union could have facilitated the flow of medical techniques in either direction.

Of course, Alexander the Great of Macedon brought both regions into the Greek-speaking world when he built his empire. He established Alexandria at the Nile delta in 332 BCE. He then proceeded close to the Indus River, and captured Taxila in 326 BCE (18), before dying at age 33 in Babylon.

Shortly after Alexander brought both Egypt and Taxila into the Greek-speaking world we do find evidence that the Greeks became aware of cataract surgery. The philosopher Chrysippus of Soli (c. 279-206 BCE) mentioned couching of cataracts. Chrysippus' works have been lost, but he was cited by Simplicius of Cilicia (c. 490-560), who in reviewing the philosophy of Aristotle and Chrysippus, wrote (33):

"For although blindness comes about from sight, [change] does not [occur] in the reverse direction as well. And because of this Chrysippus raised the question whether

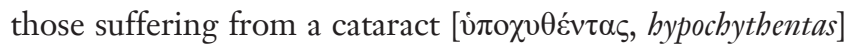
but able to recover sight after a couching of the eye

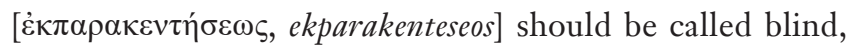
and [he raised the same question] in the case of those whose eyelids are [naturally] shut: for since the capacity [to see] exists, they resemble someone [voluntarily] keeping his eyes shut, or someone prevented by a screen $[\pi \alpha \rho \alpha \pi \varepsilon ́ \tau \alpha \sigma \mu \alpha$, parapetasma] from seeing, since if this [screen] is removed [ $\alpha \dot{\varphi} \alpha 1 \rho \varepsilon \theta \dot{\varepsilon} v \tau$ cos, aphairethentos] he is in no way prevented from seeing. So it is not from privation to possession that such a change comes about. But [Aristotle] is here considering the kind of privation which consists in a disability. For from such a [privation] there is no return to the [corresponding] possession" (34).

As Chrysippus' mention predates any established couching tools, or other mentions of the technique by centuries, we might wonder if Simplicius was simply using the language of his own day to paraphrase a more general statement by Chrysippus about healing the blind. However, the botanist Theophrastus (371-287 BCE) had used the term $\pi \alpha \rho \alpha \kappa \varepsilon v \tau o v ̃ v \tau \varepsilon \varsigma$ (parakentountes) in a nonmedical sense to describe "stirring it [a heap] with poles" (35). Moreover, multiple subsequent philosophers who cited Chrysippus also referred to this condition. Of the $2^{\text {nd }}$ century BCE philosopher Carneades it was written "his eyes went blind

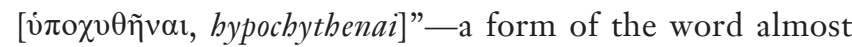
identical to that attributed to Chrysippus (36). Carneades apparently did not have surgery to restore his vision. Philospher Maximus of Tyre in the $2^{\text {nd }}$ century CE wrote "When medical science comes to the rescue...to remove the blockage so as to uncover it and restore its outward passage...The misfortune of physical embodiment covers

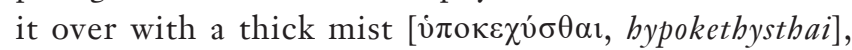
which confounds its powers of vision..." (37). Theophilus of Antioch in the $2^{\text {nd }}$ century CE referred to "cataracts

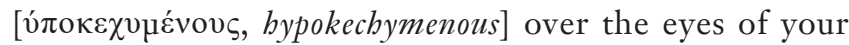
soul", and how God will "couch [ $\pi \alpha \rho \alpha \kappa \varepsilon v \tau \eta ́ \sigma \varepsilon 1$, parakentesei] the eyes of your soul" (38). Calcidius in the $4^{\text {th }}$ century CE referred to "bypochysis" obscuring vision, and also that someone having double vision from twin pupils ("geminis pupulis") would have the physician remove the "unnatural pupil through surgical intervention", perhaps by placing a scar ("cicatrice") in front of the unwanted pupil (39). Medical authors well before Simplicius had begun using forms such as hypochyma $(4,5,40)$. Therefore, Simplicius was not using a language restricted to his own day-he was using the language of philosphers since Chrysippus and Carneades. Thus, we believe that cataract surgery was known in the Greek-speaking world at the time of Chrysippus of Soli. Of course, the Greeks had heard tales from far-off lands, and therefore we cannot say if the procedure was actually performed in Greece.

Of note, the Greeks did not claim the discovery of cataract surgery for themselves. The author called pseudo- 
Galen, because he lived close in time to Galen of Pergamon (c. 129-199 CE), was apparently familiar with the practice of medicine in Egypt (41). Pseudo-Galen in Introductio Sive Medicus (Kühn 14.674-797) contrasted the Greek way of learning medicine from the Gods with the Egyptian emphasis on empiric observation (Kühn 14.674-676) (42):

"But the Egyptians also used plants and other remedies, as Homer attests when he says: 'the Egyptian, where the fertile earth produces many different drugs, many being beneficial when mixed, many being harmful'. Moreover, it is from the dissection of dead bodies when they are embalmed that many treatments used in surgery came to be discovered by the first doctors; others, it is said, were discovered by chance, such as paracentesis [ $\pi \alpha \rho \alpha \kappa \varepsilon v \tau \varepsilon i ̃ v$, parakentein] of

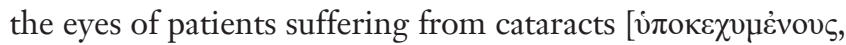
bypokechymenous], thanks to the encounter of a goat which,

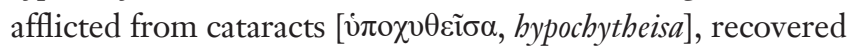
its sight after a sharp rush leaf became stuck in its eye. It is also said that the enema was invented by watching the ibis, which fills its neck with Nile water or sea water, like an enema syringe, and injects itself below with its beak..." (41).

It may enhance the credibility of pseudo-Galen to learn that the enema was indeed described in Egypt as early as the Ebers papyrus of 1500 BCE (43). Indeed, all four authors who told the story of the goat curing its cataract (Pliny the Elder, Claudius Aelianus, Leonidas of Alexandria and pseudo-Galen) drew on Alexandrian medicine or traditions.

It is unlikely that after two millenia, we would be able to learn the names of the doctors who transported cataract surgery between these two centers of learning: Alexandria and Taxila. In fact, we cannot even be sure in which direction the technique was moving! However, McEvilley in The Shape of Ancient Thought outlined known migrations of soldiers, settlers, captives, and others to Persia from India and the Mediterranean. Some even travelled all the way from the Mediterranean to India, or vice-versa, particularly during and after Alexander's reign (32). Thus, it is entirely plausible that cataract surgery could have spread from Taxila to Alexandria, or the other way around, just before the Common Era.

During the Ptolemaic and early Roman periods, we learn of a number of treatises dedicated to ophthalmology, written by Chrysippus of Cnidus, Herophilus, and Demosthenes Philalethes, all of which have been lost. In Ptolemaic Alexandria, the major surgeons and anatomists were Herophilus and Erasistratus. The teacher of Erasistratus was Chrysippus of Cnidus, who was active from about 320-280 BCE, wrote the now-lost "Treatments for
Sight", and studied under Aethlius (and perhaps the doctors in his family) (44). The works of Chrysippus of Cnidus survived at least to the time of Galen, who wrote: "the books of Chrysippus are in danger of being lost" (44). The doctors in the Chrysippus family had connections to Egypt. Chrysippus' grandfather, also of Cnidus, studied medicine under Philistion of Sicily but had travelled to Egypt with the astronomer Eudoxus (44). Another Chrysippus, the son of the Chrysippus who taught Erasistratus, was the doctor to Ptolemy Philadelphpus in 279 BCE (44).

Herophilus, wrote a now-lost treatise On Eyes, dissected the eyes of humans, and is credited by von Staden with the discovery of the optic nerve (30). Herophilus described the posterior surface of the iris and compared the retina to a net (30). Demosthenes Philalethes, thought to be of the Herophilean school, wrote a work Opbthalmicus in the first century CE, portions of which have survived in the sixth century writings of Aëtius of Amida and other works $(30,45)$.

In the first century $\mathrm{AD}$, an anonymous papyrus from Egypt (BKT 3.22-26, inv. $9764=$ Pack $^{2}$ 2354) entitled Traité Sur L'Enseignement de la Chirurgie, contains a fragment of the surgeon Archibios. The work mentions Hippocrates' teaching (Life is short and the art is long), and then states that it is absurd that students would not know the definitions of cataract ( $\dot{\jmath} \pi \mathrm{o} \chi v \mu \alpha$, bypochyma), hydrops ( $\dot{\delta} \delta \rho \omega \varphi)$, and the rudiments of surgery (46).

An Egyptian papyrus from the $2^{\text {nd }}$ century AD (P. Ross. Georg. 1. 20; $\mathrm{Pack}^{2}$ 2343, Questionnaire d'Ophthalmologie) reviews the differences between glaucoma $(\gamma \lambda \alpha v ́ \chi \omega \alpha)$, cataract (i்ỏ $v \mu \alpha \alpha$, bypochyma), staphyloma, and pterygium ( $\pi \tau \varepsilon \rho v ́ \gamma$ เov, pterygion) (46). Glaucoma could not be treated. Cataract implied a white color in the pupil, and was more treatable than glaucoma, though cataract surgery was not explicitly specified. Pterygium was operated with a hook, and staphyloma with a needle, while a flux of humors was cauterized (47).

Ophthalmic passages from the early works of Cornelius Celsus (c 25 BC-50 AD) and Pliny the Elder referred to cataract surgery, and also cited Herophilus and Erasistratus.

\section{A tale of two cities: Alexandria and Taxila}

What specific knowledge do we have of the surgical practices at Alexandria and Taxila after Alexander? Our knowledge of the surgical practices of the Alexandrian Herophilus is limited. He alluded to the extraction of a tooth, and discussed obstetric complications (30). Indeed, the only major surgery we know that Herophilus performed 


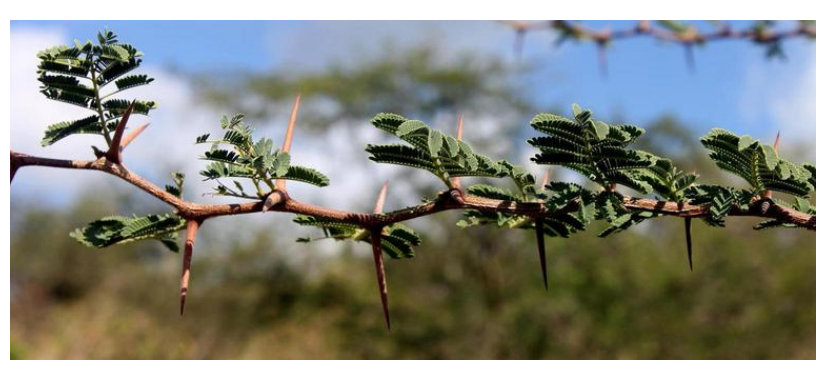

Figure 3 Thorns of Acacia nilotica, also known as Vachellia nilotica, gum arabic tree, Egyptian acacia or thorny acacia.

relates to obstetrics. According to Tertullian, Herophilus had a surgical instrument ("foetus slayer"), which had already been possessed by Hippocrates (30).

Reviews of Indian archaeology state that on the entire subcontinent, the only surviving ancient surgical tools were excavated at Taxila $(18,48)$. The surgical instruments from Taxila are made of almost pure copper (18). Wellrepresented among these instruments are "decapitators"-hooks for fetal extraction, some of which date from the $2^{\text {nd }}$ or $3^{\text {rd }}$ centuries BCE (Figure 1) (18). Fetal extraction is found in the ancient medical texts describing cataract surgery in greatest detail: Celsus, who outlined Alexandrian medicine, and Suśruta of India (18). Thus, there are important links in the surgical practices between Alexandria and Taxila, even if we cannot be sure which region originated each procedure.

\section{Construction of couching needles (Rods)}

\section{The thorn}

Although we began the discussion with the Bronze Age, it is possible to perform cataract surgery using a stone age tool: a thorn. Early surgical tools included thorns. For instance, thorns were used by the Nahuatl in Mesoamerica to lift pterygia (4). Thorns also frequently caused eye injuries throughout the world. When one has poor vision, accidentally impaling one's eye on a thorn might be more common. Thus, using a thorn for cataract couching could have arisen either by accident, or as an outgrowth of other ophthalmic surgeries by a particularly aggressive healer.

Indeed, surgeon Robert Elliot, who worked in Madras at the turn of the $20^{\text {th }}$ century, heard reports that "the long needle-like thorn of the babul-tree" was used to perform couching (49). Other names for this tree are Vachellia nilotica, gum arabic tree, Egyptian or thorny acacia, and
Acacia arabica (Figure 3) (50). Likewise, use of a thorn for couching has been reported in Nigeria (51), and in Sudan, the latter specifically from the Acacia arabica tree $(52,53)$. If ancient traditional healers practiced this way, we would not necessarily have written documentation. Even as late as the medieval period, Ammar wrote in Cairo that many of the oculists were illiterate (54). Modern day traditional oculists do not typically write about their methods, which are often kept as a family secret. In most regions of the world, written records of any kind from before the Common Era are sparse or nonexistent.

But there are hints that a thorn might have been used for cataract couching in antiquity. As noted above, four authors who drew on Alexandrian traditions told the story of a goat couching a cataract in its eye by running into a thorn (55). This might seem to be just a curious story, but we must remember that very few accounts of cataract surgery from Graeco-Roman antiquity have survived. The fact that this story was related by a significant fraction of all the GraecoRoman authors mentioning cataract surgery meant that the story must have enjoyed widespread circulation. This popular story may have served as a teaching tool. Just as the lightest eye was termed glaukos, whether in health or disease, the intermediate color eye was called the goat's eye by the Greeks, again, regardless of whether the eye was healthy or diseased (55). Goat's eyes are often colored yellow or amber, and are thus intermediate in color. A cataract seen through an undilated pupil would brighten the eye a little bit, but not enough to be in the brightest category (glaukos). Any student would have to remember that couching worked best for the goat's eye. And given the traditional healing practices which survived for millenia in India and Africa, the procedure might really have been done with a thorn. The comparison of a surgical knife to a thorn by the medieval oculist Khalifah AlHalabi of $13^{\text {th }}$ century Aleppo (see below), might have echoed earlier surgical practices.

\section{Copper needles (Rods)}

Cataract surgery instruments provide an opportunity to correlate the texts with archaeological finds. Some cataract surgery descriptions listed a single (primary) material for the couching instrument in the detailed step-by-step procedure instructions, and later listed a variety of secondary materials for couching instruments.

The earliest materials for the couching needle specified in the Indo-Greek works are copper or bronze. As noted above, the code of Hammurabi mentioned a bronze instrument 


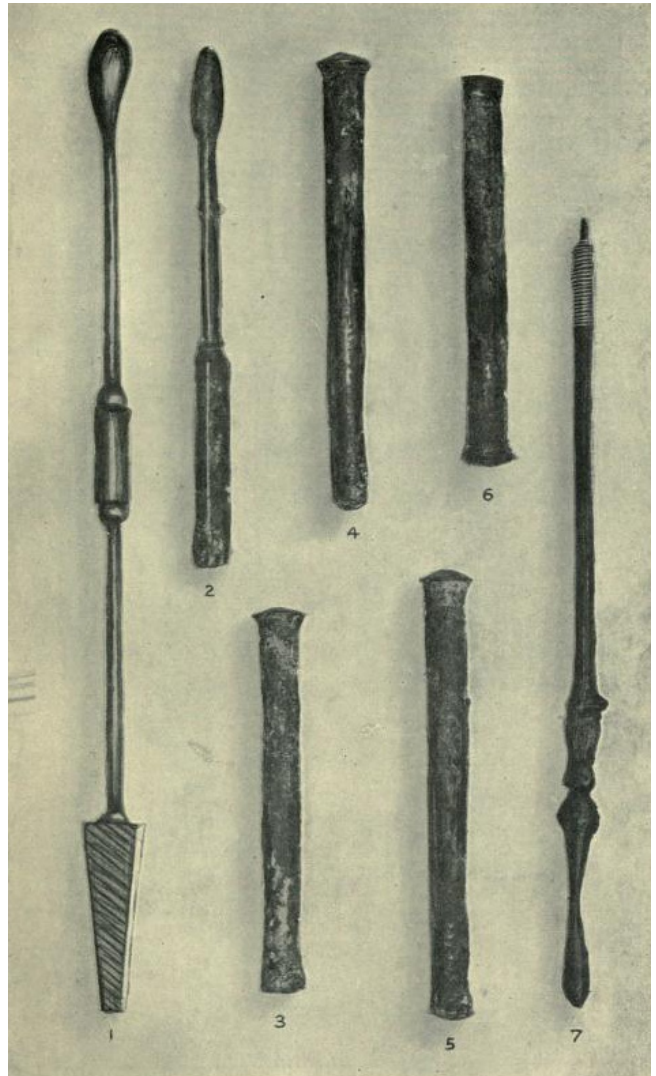

Figure 4 Roman ophthalmic instruments. Item 1: Rasping specillum for curetting granular lids from trachoma. Known as blepharoxyston in Paulus Aegineta (III.xxii), and specillum asperatum in Celsus (VI.vi). Found in Herculaneum. Olivary point at one end and plate with transverse ridges at the other. At the $15.3 \mathrm{~cm}$. Orfila Museum. Items 2-6: Instruments of the oculist Gaius Firmius Severus of the end of the third century, discovered at Rheims in 1854. Handles for needles in bronze. The steel needles, which were originally attached, have disappeared. Item 2 features an olivary enlargement, which, according to Paulus, could be used to measure distance from the limbus to perforate sclera. Held at the Museum of Saint-Germain-en-Laye. Instruments from this find had silver inlay. Item 7: $12.7 \mathrm{~cm}$. Couching needle found at a Roman camp in Bedfordshire. Contains screw thread for a cover to protect the needle. Collection of Milne.

to be used around the eye. Paulus Aegineta mentioned that the couching needle was made of copper (56). Archaeological finds have revealed bronze couching needles at sites along the Mediterranean. The best-dated would be the cataract needles buried at Pompeii, with the volcanic explosion of $79 \mathrm{CE}$. Some of the instrument tips have broken off (57-74) (Table 1). Cataract needles from Roman antiquity made at least partially from bronze have also been found at Maaseik and Wancennes in Belgium; Reims and Montbellet in France; Gandul in Spain; Italy; the island of Milos in Greece; and Southwest Asia Minor (Figures 4,5) (Table 1) (57-59,62,63,66,67,69). In the British Isles, ancient copper alloy cataract needles have been found at Piddington, Caerleon in South Wales, and Carlisle auxiliary fort (75-78). A bronze remnant of a cataract needle found at Palmyra (Syria) is thought to date from the late Byzantine or early Islamic periods (72-74). Copper continued to be the first choice for couching instruments in the works of Ṣalāḥ al-Dīn al-Kaḥhāl of 13th century Syria (79).

In the Suśrutasambitā, the primary instrument material for the couching rod was copper. The rod was described as "a barley-tipped rod-like instrument" (80). Presumably, the instrument tip resembled a barley kernel (Figure 6). We are not aware of such ancient instruments being found at archaeological sites in India, but we do have artists' renditions of instruments which might be similar (Figure 7) (81). If the artists' interpretation is correct, then the penetrating end was wider than that of the Greco-Roman couching needles.

\section{Iron needles}

The next material used to construct the couching instruments was iron (Table 1). Its use might have arisen independently in several locations (Figure 4) (62).

Iron cataract needles have been found in a shipwreck off the coast of Sicily from 200 CE (60-61). The handles of three iron instruments which were probably cataract needles were excavated from a burial site at Stanway, near Colchester, UK in 1996 (82).

Iron may have been used in the East as well. Iron was a secondary material for the couching instrument in the Suśrutasambitā (see SS 6.17 .83 above). In the text Asțāngasamgraha, surgical instruments can be made with tempered steel (1). According to the Samyuktagama (T 99:36:259c-260c) from the eastern Jin Dynasty (350-431 CE): "Tathāgata (Thus Come One) surpasses mundane physicians in ophthalmology because he understands how to cut off the cataract (timira) of ignorance with the iron of wisdom." (83).

\section{Wider portion of the shaft}

The earliest Greco-Roman and Indian descriptions of cataract surgery describe placement of an object around the 


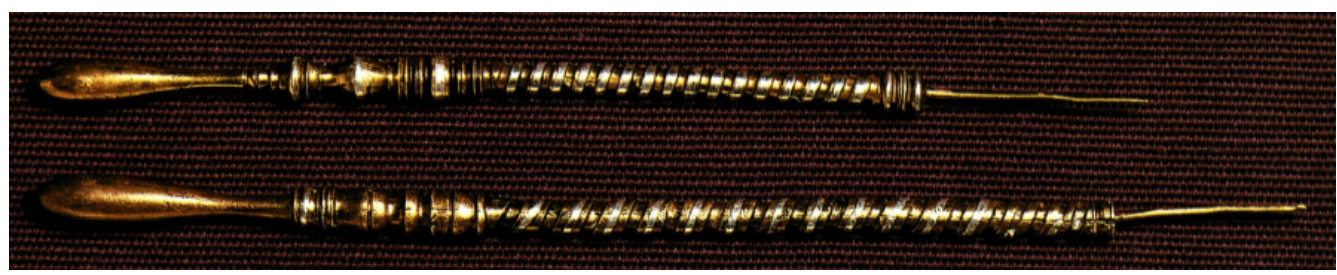

Figure 5 Solid (top) and hollow (bottom) cataract needles found at Montbellet.

Table 1 Cataract surgery instruments from continental Europe and the Mediterranean

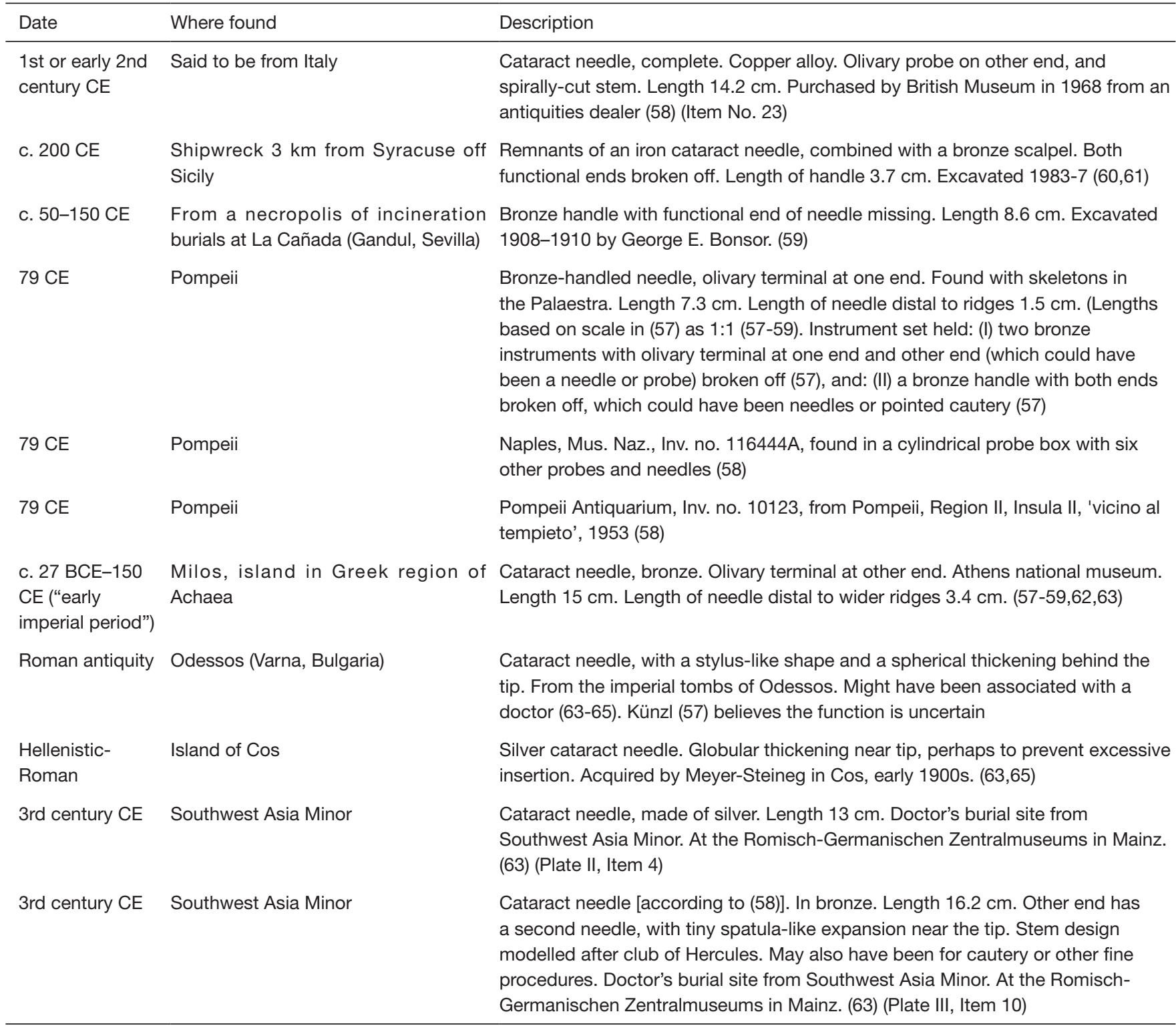

Table 1 (continued) 
Table 1 (continued)

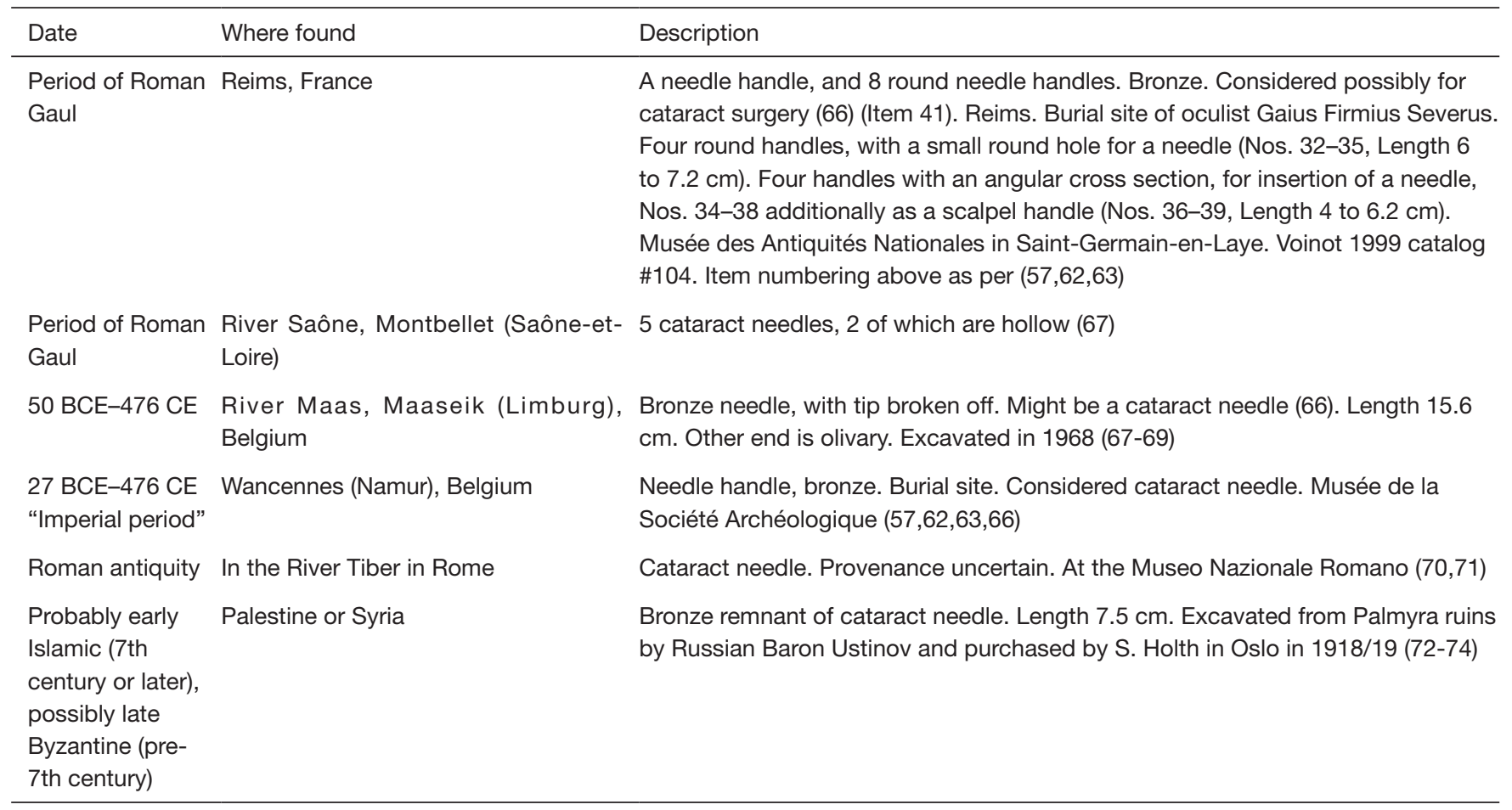

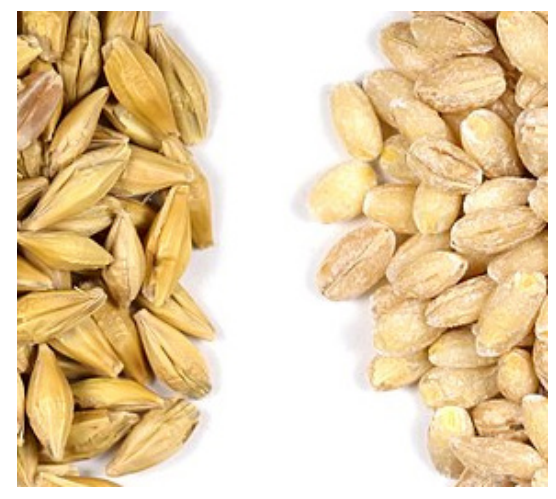

Figure 6 Barley kernels with (left) and without (right) husks.

needle to prevent excessive entry of the needle into the eye. In the Indian works, a thread is wrapped around the needle.

In the Suśrutasaṃitāa 6.17.83:

"The ideal śalākā [surgical instrument] should be eight fingers long, wrapped with thread in the centre, thick equal to joint of the thumb, bud-shaped at both ends and made of copper, iron or gold" (80).

Indeed, this practice has survived in India up to the modern era (Figure 8) $(49,84)$.
Roman couching needles prevented excessive entry of the needle with a wider portion of the shaft (Figures $4,5)$. Hirschberg indicated that he translated the cataract surgery method of Antyllus from the Continens of al-Rāzi (Rhazes), using originally just the Latin translation (54), but after 1905, supplementing this with the Escorial Arabic manuscript (6). Using these resources Hirschberg translated Antyllus as using a thread in the manner of the Indian authors:

"The cataract needle should be long enough to reach the pupil or should exceed it by the width of a barley corn, but not more. If the needle is longer then cover part of it by a thread. The needle should be kept in a sheath [indumenta, rumnanat] of copper so that is can be withdrawn whenever you want to." (6).

Hirschberg was perhaps being overly specific regarding the Latin as specifying threads, because the Continens actually mentions covering the needle with "something [aliquid]" (85). Hirschberg defended his interpretation of the Latin indumenta (rumnanat in Arabic) on the grounds that such sheaths have been found in the tombs of GalloRoman ophthalmologists (54).

However, based on the Arabic manuscripts of al- 


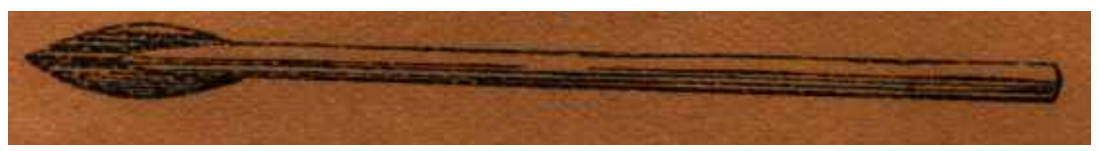

Figure 7 Artist's rendition of a salaka described in the Suśrutasambitā.

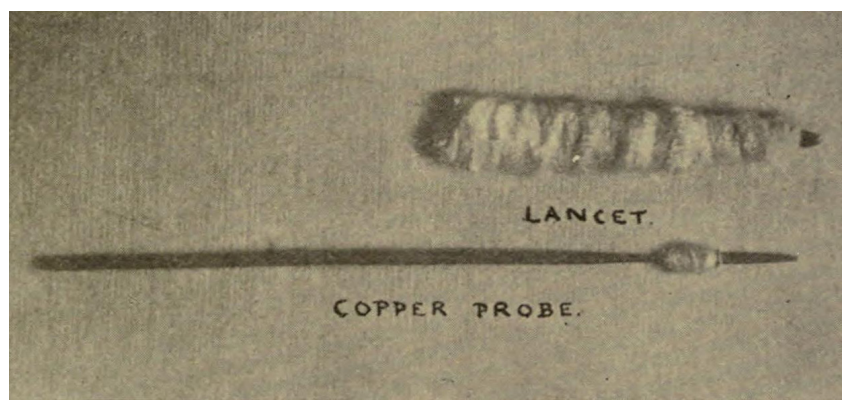

Figure 8 Copper couching needle and steel lancet wrapped in thread. The instruments match the description and drawing of the instruments acquired by Elliot's close colleague Ekambaram in Tamil Nadu in 1910.

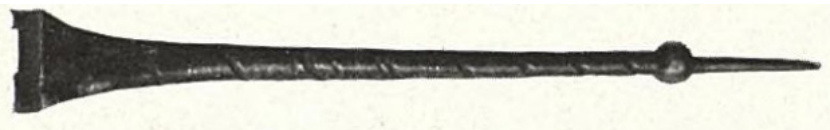

Figure 9 Silver couching needle of the Hellenistic-Roman period from the island of Cos.

Razi, others have interpreted Antyllus to recommend an adjustable metallic stop $(67,86)$ :

"The length of the needle tip is such that it reaches the pupil or exceeds the width of a grain of barley, no longer. If it is longer, attach something to it, preferably brass buttons, which you can slide on or remove as you wish" (67).

\section{Silver instruments}

Silver couching instruments were used along the Mediterranean (Table 1). A silver cataract needle with a globular thickening near the tip to prevent excessive insertion, thought to date from the Hellenistic-Roman period, was acquired by Meyer-Steineg from a local collection on the island of Cos in the early 1900s (Figure 9) (65). Another silver cataract needle came from a $3^{\text {rd }}$ century CE doctor's burial site in Southwest Asia Minor (63). The instruments of the $3^{\text {rd }}$ century oculist Severus had silver inlay (Figure 4) (62). For the hollow needles of Montbellet, silver was used for the inlay, and to construct the internal wire (Figure 5) (67). Silver couching needles were the preferred tools of Benevenutus Grassus in the $12^{\text {th }}$ or $13^{\text {th }}$ century (87).

\section{Gold instruments}

Use of gold for couching instruments seems to be an idea which spread from East to West. In general, gold was the primary material used for acupuncture needles in China (88). After cataract couching entered China, using gold for the couching needle helped to establish the practice as part of the Chinese medical tradition.

The earliest use we could find of a gold implement used to restore vision was in $6^{\text {th }}$ century Tibet, when the king Tagri Nyenzig (Stag ri gnyan gzigs), who was born blind, was healed by a doctor named Hashaje (Hazha rje) summoned from Hasha or Asha, which might be in Eastern Tibet (88), or perhaps Chinese Turkestan $(89,90)$. The surgery was performed with a "golden surgical instrument" (87). Upon restoration of his vision, the king first saw "a wild sheep (gnyan) walking in the mountain like a tiger." (88).

After a millennium, cataract surgery was again recorded in Tibet in the $17^{\text {th }}$ century (88). Tibetan surgery used an "eye spoon" (migthur) made of copper and a "She Yak's tongue spoon" (bri Ice thur) made of gold (88). Given that $20^{\text {th }}$ century Tibetan cataract couching, taught at the Lhasa Mentsikhang, involved the Greco-Roman practice of covering the contralateral eye $(88,91)$, cataract surgery was probably reintroduced or modified in the $17^{\text {th }}$ century, rather than being an unmodified continuation of $6^{\text {th }}$ century Asian practice.

In $826 \mathrm{CE}$, the Chinese poet Bo Juyi (772-846 CE), who suffered from poor vision, wrote a poem in which he debated "if the golden comb ought to be tried to regain eyesight by scraping" (92). The Chinese procedures based on the work of Nagarjuna (Long Shu or Long mu in Chinese) and subsequent Chinese works all call cataract couching the treatment with a golden needle (92). Despite the title "Surgical method with the golden needle", the text of the method itself mentions that the hairpin used for marking 
the site is bronze, but does not actually specify the materials used for the pointed needle and the heaven and earth needles actually inserted into the eye (93). We suspect that in some instances, the term "golden needle" had symbolic value, even if the material was not always truly gold.

Use of gold instruments for cataract surgery might have gradually spread westward. Gold was mentioned as a secondary possibility for the couching instrument material in the the Suśrutasambitā. It would be of interest to analyze multiple manuscripts of the Suśrutasambitā to discover when gold couching instruments were first mentioned.

Along the Mediterranean, we find gold listed as a secondary possibility for construction of couching instruments by Benevenutus Grassus in the $12^{\text {th }}$ or $13^{\text {th }}$ century (87).

In Sudan in 1908, cataract couching was said by local healers to be performed metaphorically with a "golden needle", though in reality it was a "narrow knife" (presumably the Arabic triangular-tipped needle), which was probably not of gold (94).

\section{Textual analysis}

If hard archaeological findings such as ancient texts and surgical instruments have not survived in adequate numbers to prove the origin of cataract surgery, other methods could be tried. By examining commonalities among various languages, linguists can reach a consensus on the existence of predecessor languages, such as Indo-European, even if the earliest Indo-European speakers were pre-literate. Likewise, biologists draw conclusions about the evolutionary relations between modern species based on the patterns in their DNA, even if no ancient DNA from their evolutionary precursors has survived. Thus, it is conceivable that by analyzing the similarities and differences between ancient and medieval descriptions of cataract surgery from various regions, we might begin to learn how they are related. In this review, we do not claim to present a complete or definitive analysis. We merely hope to start the process.

When a feature is present in two separate regions, we might look to see if it is more typical of the early history of one region or the other. For instance, invocations to a figure in Buddhism before cataract couching, as occurs in medieval Chinese descriptions, are consistent with the origin of cataract couching spreading to China from India, because Buddhism originated in India. Indeed, it is widely accepted that cataract couching spread from India to China $(82,92,93)$.

\section{Where East meets West: Indo-Greek ideas}

The following ideas are common to both the early Indian and Greco-Roman works, and presumably appeared quite early in the history of cataract surgery. To this list could be added the above descriptions of using thorns, copper, bronze, and iron for the couching instrument, as well as widening its shaft.

\section{The Lens as a lentil}

Lentils may have originated in the Turkey-Iraq-Syria area, but they have long been cultivated both along the Mediterranean and in India (95). The lens was compared to a lentil because of its shape in the writings of Rufus of Ephesus (80-150 CE), and the anonymous author called pseudo-Rufus $(96,97)$. Likewise, Abu Ali al-Husain Ibn Sina (c 980-1037 AD), known later as Avicenna, was familiar with the writings of Rufus and also compared the lens to a lentil (Figure 10) $(98,99)$. This understanding must have resulted from dissection of the eye to examine the shape of the lens.

Similarly, Suśruta (6.7.3-4) noted that ophthalmologists (nayanacintaka) noted of the drsțti that "its size is like that of a split lentil (masūradala)" (1). In addition, the drsțti glows like a firefly (kbadyota) or a spark, "has the form of a hole" and tolerates cold $(1,100)$. This sense of drsți might be as "pupil' more than as a crystalline lens. It is interesting that the author attributes this knowledge as having been acquired by other specialists, rather than being something he observed personally. Moreover, a statement about the size of the drsți might simply relate to the pupil being about the size of a lentil $(6 \mathrm{~mm})$, which is possible, depending upon the lighting.

\section{Intermediate age of the patient}

Both the Indian and Greek works recommended cataract surgery, and other surgical procedures, on patients of intermediate ages.

The cataract surgery chapter in the Suśrutasambita noted: "Persons declared unfit for venesection (viz., infants, old men, etc.) in the chapter on venesection should not be subjected to any surgical operation." (100). (Venesection is the cutting of a vein). This prohibition in children was not because of a concern for amblyopia. Rather, the concern expressed in the earlier volume was that the young and old would be too weak to tolerate a procedure (101). The 


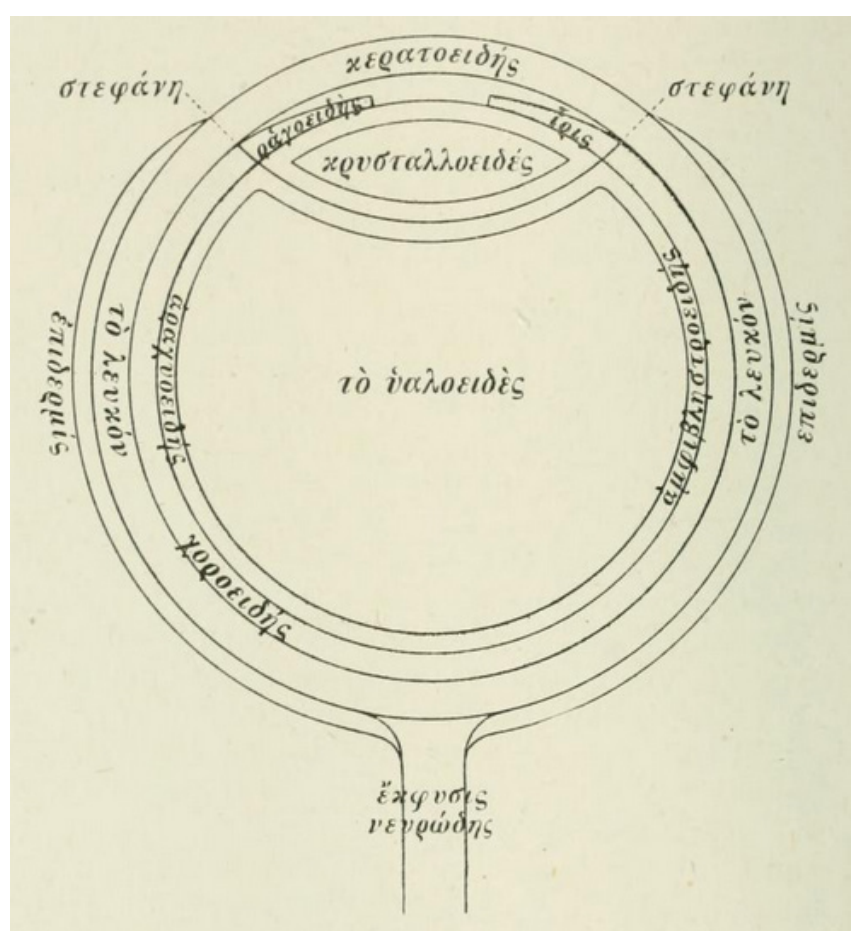

Figure 10 The anatomy of the eye, with an anterior crystalline lens, according to an interpretation of the writings of Rufus of Ephesus. Rufus compared the crystalline lens to a lentil.

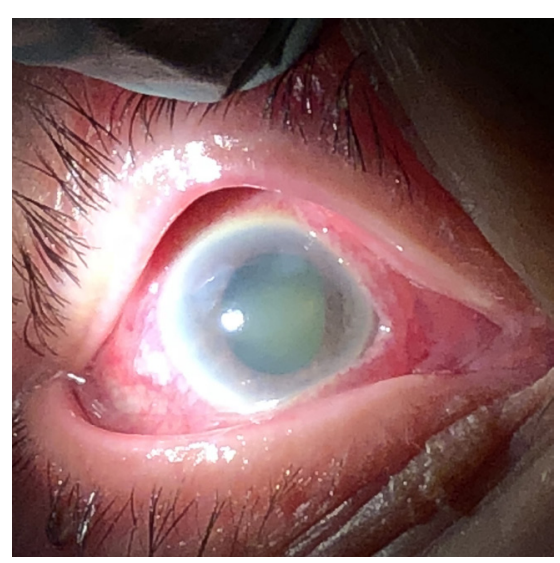

Figure 11 As shown here, the pupil in angle closure glaucoma can look green when the mid-dilated pupil exposes the opalescent lens of middle age.

earlier volume noted that because leech application was the most delicate method of letting blood, it was suitable for "children, old, timid, debilitated" patients (101). Likewise, cauterization was also prohibited in "debilitated, child, old, timid" patients (101).

Celsus wrote with respect to couching: "Old age is not favourable for treatment, since apart from this lesion, sharpness of vision is naturally dulled; neither is childhood favourable, but rather intermediate ages." (7.7.14) (102). The Biblical story of healing a man born blind seems to indicate some awareness among laypeople along the Mediterranean of the difficulty of treating congenital vision loss (John 9:32) (103). Earlier, Celsus had noted with respect to letting blood that "the ancients were of opinion that the first and last years could not sustain this kind of treatment." (2.10.1) (104). As in the Indian works, the concern was weakness of the patient. In contrast with the "ancients", Celsus based the decision for blood-letting on an evaluation of the strength of the individual patient. Hippocrates in the latter (older) portion of Diseases 2 had already advised in the treatment of various medical conditions: "draw blood from his arms, unless he is weak." (Littré VII 112) (105). Galen advised in Method of Medicine VIII: "If [the patient] is either a child or an old person, phlebotomy is ruled out. But between these ages, when bodily strength is present in the patient, you must carry out phlebotomy..." (Kühn 10.565) (106).

\section{The glaucous pupil}

As noted above, ancient cultures described many blinding conditions by the color of the pupil. Historically, languages often make no distinction between blue, green, and gray, using the same term to describe all of these colors $(5,107)$. Many corneal conditions, such as scarring, band keratopathy, keratitis, vitamin A deficiency, or edema, can lighten the cornea over a large extent of its surface. In addition, the mydriasis of angle-closure glaucoma can expose the lens, which in some cases appears opalescent (green) or gray (Figure 11) $(4,107,108)$. Thus, it is not surprising that many early cultures use the term for a glaucous eye to describe such blinding conditions. In Mesoamerica, the Nahuatl treated a diseased blue or green pupil by rubbing the eye (4). In China, blindness with a green pupil (qing mang) preceded the introduction of couching into the region (109).

Of note, some Old World societies which came into contact with people with light blue eyes used the same term to describe a healthy light blue or green eye and the lightest category of diseased eye. In Hippocratic Greece, which was a pre-couching society (as far as we know), the lightest eye category was described as glaukos regardless of whether the 
eye was a normal blue eye, or a diseased eye. Although the glaukos eye was not consistent with good vision, the glaukos eye might be transient or improve, just as a keratitis might improve. It would not hurt to try medicines, though it is doubtful that ancient medicines were typically efficacious for any conditions (40).

A transition in the significance of the glaucous hue occurred as cataract couching entered a region. Eyes with extensive light areas from corneal scarring, keratitis, etc., or those with mydriasis exposing a gray or opalescent cataract, were less likely to benefit from cataract couching, and therefore the glaukos hue was regarded as surgically incurable $(5,40)$.

During the medieval period, the Greek term glaukos was translated into Arabic as zarqaa. This term was analogous, because it described both the healthy light-colored blue or green eye, and also the diseased eye with a bright gray or green pupil (5).

In India as well, it is possible that the same word for the healthy blue eye was also used for a surgically incurable category of eye disease. The adjective nīla, "dark color, blue, or indigo" (110), which, among other things, described a pathologic pupillary color, could also be applied to presumably healthy eyes. For instance, the term abbinìla-netratā "having dark-blue eyes" (111) is found in the canonical list of 32 mahäpurușalakșana-s "Signs of a Great Man", that is, the Buddha. Meulenbeld summarized Susruta's classification of linganāśa-s "cataracts" according to their colors, among which we find two incurable types which might have a bluish hue: "...dark blue (nīla) due to pitta... [and another characterized by] a round patch (mandala), arising from blood, resembling thick glass and glowing like fire, of a faint (mlāyin), bluish (ānīla) colour, occurs in the disease called parimlāyin" $(1,100,112)$. Of note, the only type of linganāśa curable by couching was that due to kapha, which produced a white pupillary color. It is important to emphasize that although kapha is typically translated into English as "phlegm", the concept of kapha does not correlate exactly with the ancient Greek concept of phlegma, or with what we mean by "phlegm" today. Thus, pupils colored nīla or ānīla would not be surgically curable.

The parallels of Suśruta's pupillary color terms and those of Celsus are interesting. The ophthalmic chapter of Celsus mentioned two color terms which described healthy light blue eyes: caesius and caeruleus. Of the two, caeruleus might tend to a darker blue, and, like nīla in the works of Suśruta, described a pupillary hue which was not treatable with couching. Caeruleus could also describe green objects such as plants (5).

Georg Bartisch in 1583 described caerulean cataracts (Coerulea) which were the color of indigo, "somewhat glassy", and typically did not improve with surgery (113). Presumably this information was an amplification of Celsus, rather than being derived directly from the Indian works.

\section{The glassy eye}

Glass manufacture was advanced along the Mediterranean. Roman glass could be tinged green (most commonly), but sometimes amber or other colors, depending on impurities (5). Glass played a role in the physiology and pathophysiology in the Greco-Roman works. Praxagoras of Cos, who taught Herophilus, had a complicated humoral theory, which included a glassy (vitreous) humor as one of the fundamental humors (114). In a discussion of eye anatomy which cited Herophilus, Rufus of Ephesus mentioned the vitreous (byaloeide) (Figure 10) $(30,98)$. Today, we still call the clear fluid in the back of the eye the vitreous humor.

In the ancient Greek literature, a glassy appearance to the eye could also represent pathology. As noted below, a Greek papyrus from Egypt in the $2^{\text {nd }}$ century BCE noted a pathologic glassy humor in the eye. Apsyrtos of Bithynia (fl. 3rd Century CE), wrote: "When $\gamma \lambda \alpha v ́ \kappa \omega \mu \alpha$ [glaucoma] occurs, lancing is useless because [the disease] is incurable. It is a result of a so-called glazing of the eye (vón $\omega \mu \alpha$, byaloma, glassy disease) rather like a $\lambda \varepsilon v \kappa \eta[$ leuke] pebble." (5). On the other hand, Aetius of Amida, drawing on the work of Demosthenes Philalethes of the first century CE, noted

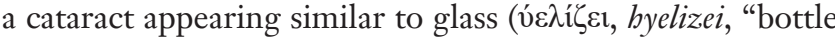
green”) which was not specified as untreable (45). This idea was promulgated by subsequent Arabic authors. Șalāh alDīn al-Kahhāāl of $13^{\text {th }}$ century Hama, Syria wrote in "The Book of Light of the Eyes" that one type of cataract "has the color of glass" (79). Khalifah of $13^{\text {th }}$ century Aleppo described a cataract "the color of glass, also known under the name of pearly cataract. It approaches being suitable for surgery." (79).

The allusion to pathologic "glass" (1), i.e., $k \bar{a} c a$, in the description of various ophthalmic disorders in the Suśrutasam̧bitā and in the Aștāngahrdayasampitā is in common with the pathologic comparison of the eye to glass 
in the Greek literature.

\section{Phlegm and the eye}

Classical Indian medicine supposed that disease was caused by an imbalanced state of individual or variously combined primary morbific agents, the so-called "doșas". There were three doșas, and their most common translations were vāta (wind), pitta (bile), and kapha (phlegm) (115). As we noted above, these translations are merely conventions to assist the reader. For example, the ancient Indian concept of pitta does not correspond with the ancient Greek concepts of black or yellow bile, or with the modern understanding of bile. The Âyurvedic theory of doșas, then, may be said to overlap with the Hippocratic system of humoral medicine only inasmuch as both systems considered health and disease to be based on balanced or imbalanced states of doșas and humors respectively.

However, as noted in a number of studies (1), the doctrine of the three doșas, which "[a]t the time when the saṃhitās [compendia] of Caraka and Suśruta assumed their present shape [...] begun to dominate āyurvedic theory, [...] was then still in flux [...]" (116). Of a special interest for us is the observation that " $t]$ he position of blood in Indian medical theory is essentially different from doṣas and dușyas [elements corruptible by doșas], in being ambiguous [...]" (116). In short, in the Suśrutasambitāa, blood assumes an intermediate position and, according to Meulenbeld's analysis, is treated in five different ways ranging from its usual place as a bodily constituent up to the position of "a doșa or at least very close to it" (116). Scharfe interpreted these features of Suśruta's humoral system as being a progression of his Indian predecessors (115). It appears possible, however, to explain the obvious inconsistency as resulting from an ongoing endeavour to accommodate elements drawn together from different systems, which could also include, for example, Greek medicine.

In our analysis of the humoral schema in the ophthalmic sections of the Suśrutasambitā, we see that blood indeed occupied an ambiguous position (Table 2) $(1,80,112,117)$.

Within the classification of linganāśa based on how it impairs patient's vision, Suśruta (SS 17.18-26ab) differentiates between those caused by (I) vāta, (II) pitta, (II) kapha, (IV) blood, (V) all doșas together, and (VI) pitta combined with blood. In the case of blood (IV), considering the immediate context, one could, perhaps, wonder if rakta is treated as a doșa here. In the case of (VI), however, the special term used here by Suśruta pittam [...] mūrcchitaṃ raktatejasa, "[p]itta combined with heat of rakta [blood]" (SS 6.7.25ab) (80) indicates that blood is considered a usual bodily element, rather than a doșa. In addition, the Greek disorders connected with black bile correspond roughly with those caused by pitta, while those connected with yellow bile correspond roughly with those caused by pitta combined with blood (Table 2).

Further passages in Suśruta seem to lump the yellow and blue (or dark) diseases together under the pitta subheading, as they are in the Asțāngasamgraha. In Indian works, if a cataract was due to anything other than kapha (phlegm), it was not suitable for surgery. Thus, those due to pitta (bile), vāta (wind), and blood were nonsurgical. While the appearance of blood in Suśruta's analysis of linganāsa could suggest Greek influence, Meulenbeld's and Scharfe's observations demonstrate that this is a general feature of the text, which is not restricted to the ophthalmic portions or the Uttaratantra.

The early Greco-Roman works on cataract agreed with the Indian that there was some sort of pathologic humor ( $\chi$ upós, chymos) which had settled in the eye to cause the disorder. Thus, the Greeks eventually called the lesion treated by couching bypochyma, and the Romans called it suffusio (suffusion). However, it was not generally clear in the Greco-Roman system exactly what this fluid causing a couchable lesion was, e.g., phlegm, bile, blood, etc.

However, occasional Greek references did specify abnormal phlegm settling in the eye. The work Diseases 2, traditionally attributed to Hippocrates, referred to phlegm in the pupil of the eye, but the patient recovered without surgery:

"Patients see unclearly, in this condition, when phlegm enters the small vessels of their eyes; for the pupil becomes more watery and turbid, so that the clear part of the eye is no longer as clear as it was, and thus the image does not appear in it, when it wishes to see, the same as when it was clear and pure. This patient generally recovers in forty days." (Littré VII 8) (105).

Diseases 2 might be a composite work, with certain portions, including the above quotation, postdating the Hippocratic era (118). The corresponding passage from the older portion of Diseases 2, which is believed to date from the Hippocratic era, states that this disease ends if "fluid and mucus break out through his nostrils or ears", though "the sight is snatched from his eyes, and he seems to see only the half of faces." ( Littré VII 20) (105). Thus, the older version 
Table 2 Ayurvedic humoral theories of eye disease

\begin{tabular}{|c|c|c|c|}
\hline Dosa & $\begin{array}{l}\text { Color of } \\
\text { linganāśa }\end{array}$ & Pupil appearance & Patient sees \\
\hline Kapha & White & $\begin{array}{l}\text { Thick, glossy, pale white } \\
\text { resembling conch shell, } \\
\text { kumuda flower and the } \\
\text { moon; like white drop of } \\
\text { water placed on a moving } \\
\text { lotus leaf; on rubbing the } \\
\text { eye, the circle spreads (SS } \\
\text { 30cd-31cd) }\end{array}$ & $\begin{array}{l}\text { Objects as glossy and white like white chowrie or white clouds and excessively } \\
\text { large. He also sees clouds moving the cloudless sky and objects inundated } \\
\text { with water and stiffened. ( } 20 \text { cd-22ab); White like śañkha (conch), the moon, } \\
\text { kuñdakusuma, kumuda (white water lily), and sphațika (rock crystal) (AS) }\end{array}$ \\
\hline Vāta & Reddish & $\begin{array}{l}\text { reddish, unstable and } \\
\text { rough (SS 29cd) }\end{array}$ & $\begin{array}{l}\text { Objects as revolving, dirty, reddish and crooked (18cd-19av); Web of hairs, } \\
\text { mosquitos, rays of light, face without the nose, straight objects appear curved, } \\
\text { dusty, smoke (AS) }\end{array}$ \\
\hline Blood & Red & $\begin{array}{l}\text { Lustrous like coral and } \\
\text { lotus leaf (SS 31ef) }\end{array}$ & Red, dark, green, black grey like smoke (SS 22cd-23ab) \\
\hline $\begin{array}{l}\text { All doșas } \\
\text { together }\end{array}$ & Variegated & Variegated (ss 32ab) & $\begin{array}{l}\text { Variegated, scattered in multiplied or double forms, with deficient of excessive } \\
\text { parts, or stars (SS 23cd-24) }\end{array}$ \\
\hline
\end{tabular}

did not specify phlegm entering the eye.

A Greek ophthalmic papyrus $\left(\mathrm{Pack}^{2} 342\right.$, Traité d'Opbtalmologie) from the first half of the third century BCE from Hibeh, Egypt, has been attributed, based on the style, to either Diocles of Carystus or Chrysippus of Cnidus, but the fragmentary nature of the document makes attribution difficult. The treatise mentions pneuma $(\pi v \varepsilon v \mu \alpha)$, phlegm $(\varphi \lambda \dot{\varepsilon} \gamma \mu \alpha)$, and hardness ( $\sigma \kappa \lambda \eta \rho o ́ \tau \varepsilon \varsigma$, sklerotes) as relevant to ophthalmology, possibly with respect to mucoid discharge or mattering (46).

From a Greek papyrus ( $\mathrm{Pack}^{2} 2344$, Traité d'Ophtalmologie) of the second century BCE from the Roman province of Arsinoë, Egypt, there is the suggestion of a pathologic phlegmatic, glassy humor in the eye causing a coloration of the pupil described as glaukomaton:

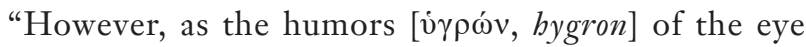
have been crushed and the wound is contused, this disorder typically produces a gray-blue coloration $\left[\gamma \lambda \alpha v \kappa^{\kappa} \omega \sigma \mathrm{v}\right.$, glaukosin]. In effect, the gray-blue colorations [ $\gamma \lambda \alpha \nu \kappa \omega \mu \alpha \dot{\tau} \omega v$, glaukomaton] appear when a phlegmatic $[\varphi \lambda \varepsilon \gamma \mu \alpha \tau \omega \delta \delta \varepsilon \varsigma$,

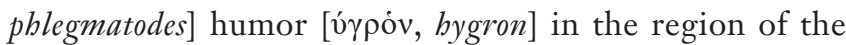
pupil, and that engenders a cold: that is also why this humor is glassy [ن่ $\alpha \lambda \omega \delta \delta \varepsilon \varsigma$, byalodes] in color and consistence." (46).

Celsus in book V noted that "wild poppy-heads" could help to "check the flow of phlegm into the eyes" (119). In book VI of Celsus, the idea of phlegm in the eye is most strongly related to the Indian concepts, because phlegm accounted for bypochysis--the same term Celsus used for the couchable lesion:

"Cataract also, which the Greeks call bypochysis, sometimes interferes with the vision of the eye. When it has become long established it is to be treated surgically. In its earliest stages it may be dispersed occasionally by certain measures: it is useful to let blood from the forehead or nostrils, to cauterize the temporal blood vessels, to bring out phlegm by gargling, to inhale smoke, to anoint the eyes with acrid medicaments. That regimen is best which makes phlegm thin." (119).

Celsus' recommendations resemble those of Susruta for Adbimantha (ophthalmia) caused by kapha (100).

The humoral basis for the various colors of cataract became most advanced in the works of Șalāh al-Dīn alKaḥhāl of $13^{\text {th }}$ century Hama, Syria, reaching a level of complexity equivalent to the Indian doctrines. Șalāh al-Dīn 
believed that excess mucous caused most cataracts, but he separated black and yellow bile, in the manner of the Greek authors (79).

\section{A sense of humors}

The early Indian works of Suśruta and Vāgbhața state that the type of entity (doșa or blood) in the eye determined not only the appearance of the pupil to the doctor, but also tinged the vision of the patient correspondingly. Thus, kapha (phlegm) made the pupil look white and the patient see white. Blood in the eye made the pupil look red, and the patient see red. Bile in the eye could make the patient see yellow (Table 2).

Numerous Indian philosophers have debated the significance of the finding that "When the jaundiced individual sees the conch shell as yellow, a non-jaundiced individual will see it as white." (120).

The earliest datable record of this idea comes from the Roman poet Lucretius, who wrote in 50 BCE: “...whatever jaundiced people view, becomes wan-yellow...” (121). The Romans sometimes compared jaundice to the color of gold (aurugineus or aurugo) (122). Thus, Celsus' description of one incurable cataract as golden in color (5) might correspond with the idea that cataracts could be caused by bile.

In the Greek works, this idea is well-represented with respect to yellow bile and blood. Sextus Empiricus wrote in Outlines of Pyrrhonism: "Thus, sufferers from jaundice declare that objects which seem to us white are yellow, while those whose eyes are bloodshot call them blood-red... Surely, then, we have much more reason to suppose that when different juices [ $\chi \cup \mu \tilde{\omega} v$, chymon] are intermingled in the vision of animals their impressions of the objects will become different." (123). This is particularly interesting because Sextus Empiricus was relating the philosophy of Pyrrho, who accompanied Alexander the Great to India, including Taxila $(31,32,124)$.

This idea became a mainstream medical concept. Galen wrote in On Diseases and Symptoms:

"If the fluids... are changed in colour, a false vision (parorasis) involving the nature of those things occurs...those who are jaundiced seem to see everything as pale yellow but those who have suffered a hyphaema (byposphagma) as red." (Kühn 7.99) (125).

Likewise, Ibn Isa wrote that if the cornea is red from blood, objects appear red, but if one has jaundice, the yellow color of the cornea makes objects appear yellow (126).

\section{Rubbing the eye}

Many groups throughout history have therapeutically rubbed the eye (4). In the Indo-Greek writings, the eye is rubbed, either to stabilize it, to check the character or maturity of the cataract, or to prepare the cataract.

In Suśrutasṃbitā 6.7.29-32, "In linganāśa (mature cataract), the circle [...] due to kapha [...] is thick, glossy, pale white resembling conch-shell, kumuda flower and the moon; it is like white drop of water placed on a moving lotus leaf; (it constricts excessively in the sun and dilates in the shade) while on rubbing the eye the circle spreads." (80)

Vāgbhata I recommended rubbing the eye just before puncture with the needle. This was not to check suitability or maturity of the cataract, as the decision for surgery had already been made.

"...pull down the upper lid [of the left eye] with his right hand, massage the area of tāraka (cornea and pupil) with the middle of the thumb, thereby dispersing the dosas... " (Asțāngasamgraha 6.17.7) (117).

In Antyllus, Paulus, and ibn Isa, rubbing the eye preoperatively became part of the test for maturity, as noted below.

\section{Maturity of the Cataract}

The crystalline lens hardens as a person ages, and when it is couched while very soft, it breaks up, rather than moving into the vitreous intact. Evaluating the hardness, or maturity, of the cataract was found in the earliest IndoGreek writings. Eventually, it came to incorporate more primitive doctrines of evaluation of pupillary color, rubbing the eye, and blowing on the eye. In addition, the GrecoRoman works (beginning with Antyllus) added that the cataract could be too hard to be reliably couched, and that those of moderate consistence were ideal.

Celsus wrote: "And in the cataract itself, there is a certain development. Therefore we must wait until it is no longer fluid, but appears to have coalesced to some sort of hardness." (7.7.14) (102).

Suśrutasambitā 6.17 .79 noted that "The disorder occurs [...] also if punctured in too immature [taruna-] stage" (80,127). Likewise, the Aștāngabrdayasambitā noted that couching for cataract (linganāśa) is performed when it is due to kapha and is ripe (sujāta) (1). 


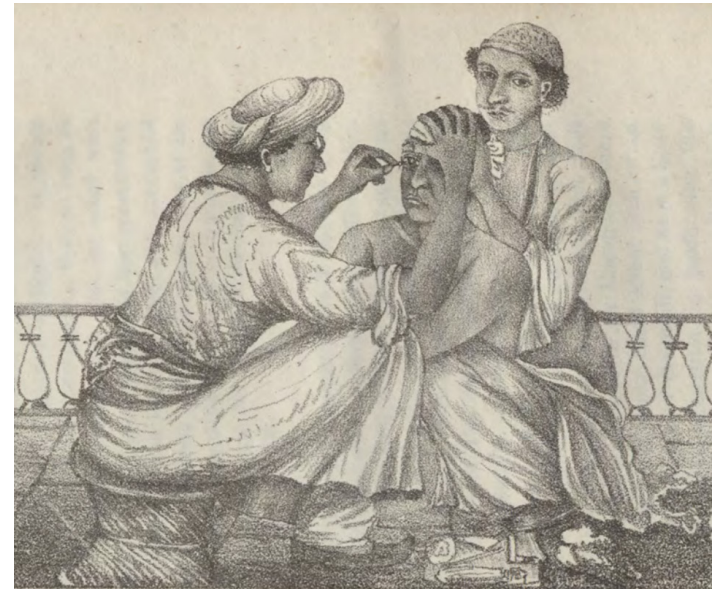

Figure 12 This positioning of the patient and oculist observed by Peter Breton in Calcutta in 1826 could have been observed at any time since the period of Celsus or Suśruta. The surgery is outside, the patient sits close to the ground, the doctor sits a little higher, and uses the left hand for the right eye (ambidexterity). An assistant holds the head. The modern origins of the scene are revealed by the spectacles worn by the doctor.

According to al-Rāzī (Rhazes), Antyllus held that deformation of the cataract when the eye was rubbed, and the pupillary colors, were both relevant to assessment of cataract maturity:

“Antilus [Antilis] says: 'A cataract [Catarracta] occurs in the eyes from the coldness of the complexion, and is brought together by the coldness of the air and the humidity of the eyes: and it is cured with perforation [perforatione], which is for a moderate congealing; and when it is for a strong congealing that is too subtle, it is not cured by perforation, and when the brow is rubbed with the thumb and moved, and it does not seem to move from its place nor does it return, it is a congealing. And that which is of an iron [ferrei] or lead [plumbi] colour reflects a moderate congealing: and it should be perforated: and that which is of the colour of gypsum [gipsei] or snow [niuis] is too dense: and it should not be perforated.' I say that care should be taken in these matters. I found this in the book of congregation [libro congregationi]. It said that patients should not vomit: because vomit induces the flow of rheum." (85).

Both Paulus and ibn Isa followed Antyllus' teachings in this regard $(56,126)$. Paulus added that the color kuanochroa, which was dark when used in the context of eyes, was of moderate consistence (appropriate for couching).

\section{Patient positioning}

In the early Indo-Greek writings, the patient is presumably outside (at least a room is not unambiguously described) and sits close to the ground, in a bright area, facing the sun's direction, but typically not in direct sunlight. The doctor is somewhat higher than the patient, and an assistant holds the patient's head (Figure 12) (2). In Celsus, there is some ambiguity about whether the patient is outside, as the Latin word loco can represent a place, as opposed to just a room. According to Celsus:

"...he [the patient] is to be seated in a light place, with his face towards the light, in such a manner that the physician may sit opposite to him, a little more elevated: but an assistant should stand behind the patient, that he may hold his head immovable." (7.7.14) (102).

According to Antyllus:

"Antilis: For the cataract operation the patient is seated in a shadow and faces the sun. The head of the patient is held firmly..." (6).

According to Suśruta (SS 6.17.57):

"...the patient should be positioned [seated] and held firmly..." (80).

Vāgbhata I wrote:

"....in the morning, select a place devoid of breeze and bright light, make the patient sit on a soft bed spread on the ground facing the sun, extending both his legs, placing the palms of both his hands firmly on the ground; another attendant sitting comfortably at the back of the patient should make the head of the patient slightly bent down but with the face up and hold it firmly with the help of his hands $[\ldots]$ the physician sitting on a stool not very high, placed on the forelegs of the patient..." (AS 6.17.7) (117).

Paulus Aeginaeta, recording Galen's method, wrote: “... having placed the patient opposite the light, but not in the sun..." (56).

Ibn Isa advised:

"...let him be seated in shadow but facing the light. Choose a northern exposure, and preferably, a summer's day... The patient should sit on a soft pillow; bind his knees together in front of his body, also tie his hands to one another and to his thighs. You should sit on a chair (or stool) correspondingly higher (than the patient)...During the operation an assistant should stand behind the patient and hold his head." (126).

Abū al-Qāsim Khalaf ibn al-'Abbās al-Zahrāwī al-Ansari (936-1013 CE), known later as Albucasis, wrote: "You should advise the patient to sit down cross-legged before 


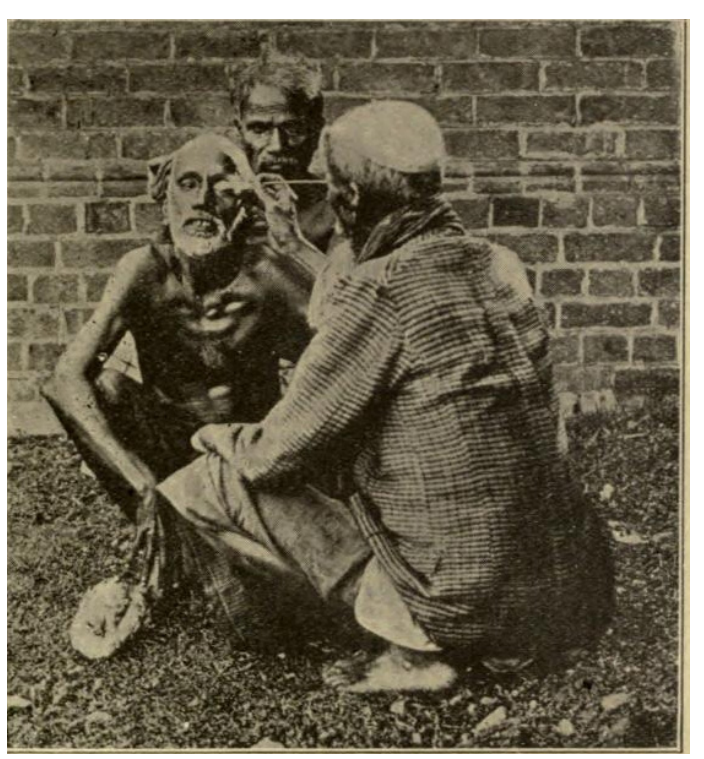

Figure 13 Cataract couching performed outside with doctor and patient squatting. The scene might correspond with the events witnessed by Elliot's close colleague Ekambaram, who had observed couching in Tamil Nadu in 1910.

you, facing the light in full sun..." (128).

Khalifah of $13^{\text {th }}$ century Aleppo advised:

"The patient should then be seated in the shade, facing the light. He should sit facing the sun...Let the patient sit on a cushion. Bring his knees in close to his chest and have him hold his thighs together with both hands. You sit on a chair somewhat higher than the patient." (79).

In Suśruta, sitting was the position recommended for all surgical procedures:

"Hence the surgeon intending to perform any of the above operations should arrange [instruments]...and also attendants affectionate, firm and strong...the patient should be given light diet and be seated facing eastward, his movements being restrained; now the surgeon facing westward should apply the sharp instrument following the direction of hairs and avoiding vital spots, veins, ligaments, joints, bones and arteries..."(SS 1.5.7) (101).

So also, for instance, in surgery of eyelid lesions: "In patient having been uncted and well positioned [seated] ..." (SS 6.16.3) (80). Pterygia were also treated by Suśruta in a sitting posture (see below). According to Celsus (7.7), in contrast, the patient could either sit or lay down for pterygium surgery, depending on the eye being treated (102).

Not until the writings of Ibn Sina (Avicenna) do we have the first clear indication of the patient being indoors during the surgery: "The patient should not be near a window when you are doing the surgery" (96).

Having the doctor and patient close to the ground survived into the modern era-often with the doctor just as low as the patient. Elliot's colleague observed a couching procedure performed in Southern India with both parties squatting outside (Figure 13) $(49,84)$. In $20^{\text {th }}$ century Tibet, couching was performed indoors with both the patient and doctor sitting on the floor facing each other, with an assistant holding the head (91).

\section{Temporal approach: ambidexterity and ocular convergence}

A temporal approach is found uniformly in the IndoGreek literature. Two related features are found in both Indian and Greek sources: (I) ambidexterity of the surgeon, which seems to be emphasized more in the Mediterranean literature, and (II) ocular convergence towards the nose, which is reminiscent of Indian meditative practices (Figure 12) (2).

In the cataract description of Celsus, "the left eye should be operated on with the right hand, and the right eye with the left hand." (7.7.14) (102). Likewise, Paulus Aeginaeta recording Galen's method, wrote: “...if it is the left eye we operate with the right hand, or if the left eye with the right..." (56). Albucasis also advised ambidexterity, operating with the ipsilateral hand (128).

In Celsus' work, ambidexterity was praised beyond the cataract operation. In general, Celsus noted that the good surgeon was "ready to use the left hand as well as the right" (7.0.4) (102). Celsus recommended when sewing abdominal wounds that “...the surgeon's left hand pushes the needle from within outwards through the right margin of the wound, and his right hand through the left margin..." (7.16.4) (102). On the other hand, for pterygium surgery Celsus was willing to move the patient to prevent the surgeon having to switch hands (102).

Ambidexterity had long been hailed by the Greeks. Homer wrote in the Iliad 21 that "the warrior Asteropaeus hurled with both spears at once, since he was ambidextrous $\left[\pi \varepsilon \rho 1 \delta \varepsilon \dot{\xi}\right.$ los, peridexios]." (129). In the $6^{\text {th }}$ century BCE, the poet Hipponax wrote: "for I have two right hands $[\dot{\alpha} \mu \varphi \downarrow \delta \varepsilon \dot{\varepsilon} \xi 10 \varsigma$, amphidexios] and I don't miss with my Punches" (130). Hippocrates in Aphorisms insisted that "A woman does not become ambidexterous $[\dot{\alpha} \mu \varphi \imath \delta \dot{\varepsilon} \xi 10 \varsigma$, amphidexios]." (131). Plato in Laws VII praised the Schythian 
warriors, who with bow and arrow could "use either hand for both purposes" (132). The Old Testament figure Ehud had a right hand which was "bound", which might have indicated that he had been trained to use his left hand. Ehud was able to stab the Moabite king using his left hand (Judges 3:12-26). The Septuagint, the Greek translation of the Bible from Egypt in the $3^{\text {rd }}$ and $2^{\text {nd }}$ centuries BCE,

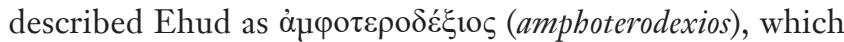
has been translated as "ambidextrous" (133). Aristotle wrote in Historia Animalium II: "Man is the only animal which can actually become ambidextrous $[\dot{\alpha} \mu \varphi 1 \delta \varepsilon \dot{\varepsilon} \xi 10 v$, amphidexion]." (134). He also wrote in Nichomachean Ethics that "by nature the right hand is stronger, yet it is possible that all men should come to be ambidextrous." (135). Finally, in the $6^{\text {th }}$ century CE, Procopius of Caesarea related that the warrior Althias caught a spear with his right hand, "And with his left hand he drew his bow instantly, for he

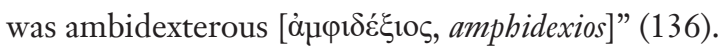

Descriptions of cataract surgery in the Indian works included ambidexterity of the surgeon, and added that the patient gazed at his nose during the procedure.

Because some aspects of the cataract operation in the Suśrutasambitā have been debated, we provide the Sanskrit text and our own translation of the beginning of the procedure (SS Ut 17.57-60):

"snigdhasvinnasya tasyātha kāle nātyuṣnaśîtale | 6.17.57ab |

Then, in a season which is neither too hot nor too cold, of [the patient] who underwent [therapeutic] unction and sudation.

yantritasyopaviștasya svāṃ nāsām paśyataḥ samam | | $6.17 .57 \mathrm{~cd} \mathrm{II}$

who is held (that is, restrained) and seated, gazing at her own nose evenly,

matimān śuklabbāgau dvau kṛ̦̣nān muktvā by apāngataḥ । 6.17.58ab

a wise [doctor] surely leaving two white parts from the dark [circle] on the side of the outer canthus

OR: ... leaving two white parts from the outer canthus towards the dark [circle]

unmīlya nayane samyak sirājālavivarjite || $6.17 .58 \mathrm{~cd}$ | |

nādho nordhvam na pārśvābhyām chidre daivakrte tatah । $59 \mathrm{ab}$

having properly opened both eyes (of the patient), should then pierce into-that is, not above, not below and not to the sides-the natural opening, which is free from the network of vessels,

śalākayā prayatnena viśvastam yavavakrayā || $6.17 .59 \mathrm{~cd}$ | |

madhyapradeśinyangușthasthirahastagṛhītayā । dakșinena bhișak savyam vidhyet savyena cetarat I | 6.17 .60 । ।

with effort and confidence, with an instrument, whose tip [resembles] barley grain and which is firmly held in hand with the middle finger, index finger and the thumb; [he should pierce] the left eye with the right hand and with the left the other one."

Likewise, after explaining that the right hand held the needle to puncture the left eye, Vāgbhata I elaborated:

"...the patient should be asked to look at his own nose and other eye...Treatment for right eye should be done in the same manner, using the right hand to pull up the eyelid and with the other hand (left hand) for puncturing sitting on the right side of the patient." (AS 6.17.7) (117).

Even though Suśruta included ambidexterity in the cataract operation, he did not emphasize it elsewhere. For Suśruta, ambidexterity was not hailed as the mark of a good surgeon, and each hand usually had specific tasks, rather than alternating depending on the side of the patient. For instance, when applying añana (kohl or collyrium), "The careful physician, holding the eye obliquely with his left hand, should apply collyrium at the inner canthus by his right hand with a rod ...” (SS 6.18.64) (80).

Antyllus was the only Greco-Roman author to have the patient gaze at his nose during the cataract operation:

"He [the patient] is asked to look with the affected eye toward his nose; this is therefore a kind of squinting toward the nose" (6).

In fact, while both Antyllus and Ibn Sina mentioned ocular convergence, neither specified the hand used by the surgeon (99).

Ibn Isa advised both ambidexterity of the surgeon and to "Instruct the patient to direct his gaze towards his nose" (126).

Looking at the nose is a well-known posture in traditional yoga, and dates from the ancient period in India, according to some (137). For instance, the Bhagavad Gita advised during meditation: "Then let him sit...Remaining still, holding the body, head and neck erect, let him fix his gaze on the tip of his nose, without looking around." (138).

A skeptic might argue that a temporal approach is ideal, and therefore ambidexterity must follow. However, Ammar of Cairo had the patient look towards the nose, but seemed to advise that the right hand be used in all cases (79).

Moreover, even a nasal approach can be used. For instance, Yen K'e Ta Cb'uan "The Most Complete Eye Book" written about $1628 \mathrm{AD}$ in China, advised surgery using the right hand, even if a nasal approach must be used: 


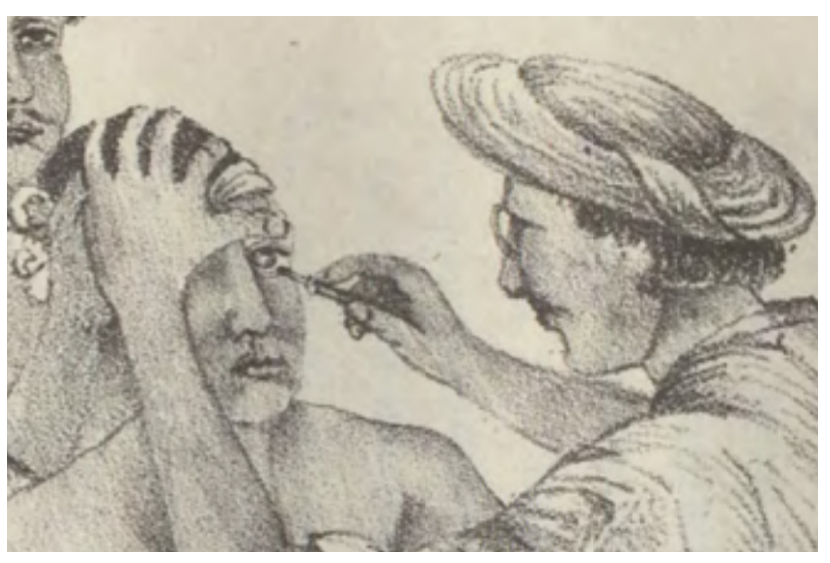

Figure 14 Detail from the observations of Peter Breton of a Calcutta oculist in 1826 shows the right hand operating on the left eye, with the needle entering posterior to the limbus, close to the pars plana.

"The eye is opened by the operator with his thumb and index finger of the left hand...while operator's right hand holds the needle. If the right eye is operated upon, the patient must look toward the right; otherwise the bridge of the nose will interfere with the operation." (139).

Of note, one early Chinese work (Longshu pusa yanlun, Treatise of Bodhisattva Nagarjuna on Eye Diseases) recommended a temporal approach and surgical ambidexterity, without mentioning gazing at the nose (140). However, neither ambidexterity nor ocular convergence was advised in the later Chinese works.

\section{Pars-plana puncture avoiding vessels}

In the Indo-Greek works, couching is performed with pars plana entry of a needle or rod, making sure to avoid blood vessels (Figure 14) (2). (The ancients did not use the term pars plana, or have a modern understanding of the anatomy of this region. However, previous work (141), as well as the analysis presented below, suggest that in antiquity the couching instrument entered the eye at the pars plana). In the earliest Roman work (Celsus) and earliest Indian works (Suśruta and Vāgbhața) the primary instrument (needle or rod) is directly applied to, and punctures, the sclera at the pars plana. A detailed analysis of the early GrecoRoman works (Celsus, pseudo-Galen, and Paulus Aegineta), supported by experiments, confirmed that the approach was pars-plana (141). For Celsus, the needle penetrated at an intermediate point between the limbus and the external canthus, which many people have interpreted to be at the half-way point, though the original text is not completely specific:

"Thereupon a needle is to be taken pointed enough to penetrate, yet not too fine; and this is to be inserted straight through the two outer tunics at a point intermediate between the pupil of the eye and the angle adjacent to the temple, away from the middle of the cataract, in such a way that no vein is wounded." (7.7.14) (102).

The distance from the limbus to the lateral canthus was on average $9.0 \mathrm{~mm}$ in adults when we asked them to gaze straight ahead (because no other direction of gaze is specified in the above Greco-Roman works). If the puncture were at half the distance, it would be at $4.5 \mathrm{~mm}$, while the pars plana extends to about $6 \mathrm{~mm}$ posterior to the limbus (141).

The works of Suśruta and Vāgbhața I and II appear consistent with the description in Celsus. As noted above, Suśruta advised to make the puncture:

"two white parts from the dark [circle] on the side of the outer canthus... [the doctor] should then pierce into... the natural opening, which is free from the network of vessels..."

This wording suggests a scleral puncture, though, as with Celsus, the exact location is hard to interpret. Some translations of the Suśrutasambitā have interpreted the "two white parts" to be two-thirds of the total distance from the limbus to the external canthus, as specified by Vāgbhața I and II (see below). Ammar of Cairo recommended the same fraction (two-thirds), but of a different distance: he punctured "two thirds of a barleycorn from the black part (limbus)" (79).

If we accept that the Suśrutasambitā instructed to puncture two-thirds of some distance from the limbus, we next might ask what the distance was. The natural first assumption might be the distance between the two objects specified-the limbus and the lateral canthus, as in the works of Vāgbhața I and II. However, this distance is on the high side-on average $6 \mathrm{~mm}$, and even higher if the patient gazed nasally, as specified in the Indian works. This posterior placement would run the risk of retinal injury.

There are several possible solutions. First, as we outline in Supplementary 1, the Sanskrit is actually ambiguous, and could be interpreted as measuring two-thirds of the distance from the lateral canthus towards the limbus. This would make the placement $3.0 \mathrm{~mm}$ for patients looking straight ahead, or a bit more for patients converging to look at the nose. Thus, the puncture would be pars plana. 
Ambiguities in the Sanskrit notwithstanding, it seems likely that the surgeon would be predisposed to measure the distance for puncture relative to the limbus. The distance to the canthus varies slightly with age, sex, race, and refractive error (141). Moreover, the relation of the canthus to the intraocular structures varies from moment to moment, depending on the abduction or adduction of the eye. Thus, the canthus is an unreliable landmark for ocular penetration. Every ancient and medieval author who clearly specified the measurement direction began at the limbus. Even today, we measure the entry site for eye injection and incision relative to the limbus for both pars-plana or anterior segment approaches. The limbus provides a reliable reference point.

One consideration is the overall relation of traditional ophthalmic practice to scholarly treatises. Ophthalmic practice existed in all societies even before there were any books, and this practice developed and evolved regardless of what the scholars ultimately wrote about it. Traditional healers often passed knowledge down from generation to generation within families, typically without any written materials, and often attempting to keep their methods secret $(84,142)$. Later, apprenticeships served to convey medical practices. But the actual craft of surgery was still learned by hands-on experience with a teacher. This is still true today, despite the ready availability of books.

Beginning with the medieval period, we have surviving books written by high-volume, dedicated oculists, such as Ibn Isa of Baghdad or Ammar of Cairo, who can truly relate how they performed surgery, and what they were thinking while operating. In contrast, many of the surviving medical books are essentially general medical encyclopedias. On this list we might include the Suśrutasambitāa, and the treatises of Vāgbhața I and II, Celsus, Paulus Aegineta, and Ibn Sina (Avicenna). The authors (or revisers) of these texts sought to incorporate a framework provided by prior scholars, and update it with the latest theoretical and practical information. These authors may (or may not) have seen or performed a small number of any particular type of surgery, e.g., cataracts, lithotomy, etc. Thus, the books did not always define ophthalmic practice-rather, they reflected it. For instance, Hirschberg concluded from Ibn Sina's description of cataract surgery that it "characterizes somebody who did not know anything about this operation." (54). When reading descriptions of eye surgeries from one of these encyclopedias, we may not know if the author (or editor) was a generalist scholar, or a dedicated oculist. Even after the emergence of treatises from dedicated oculists, such as Ibn Isa and Ammar, it is still possible that the evolution of ophthalmic practice had a life of its own, independent of the books. Ammar demonstrated cataract surgeries for his students, and so practical hands-on teaching continued to be important in the medieval period and into the modern day.

With that context, we can return to the question of the site of scleral puncture. In practice, the exact puncture site probably varied to some degree, depending on local practice and the experience of the surgeon (or his teacher). There is no particular reason to think that the variation in antiquity would be less than in the modern period. In 1826, Peter Breton of Calcutta observed the puncture site to be "about a tenth of an inch from the margin of the cornea, and a little below the axis of the pupil." (2). In 1895, British surgeon Drake-Brockman observed in India that it was done by "piercing the sclerotic with a small lancet...close to the cornea in the lower and outer quadrant." (142). In contrast, in 1910 , he reported that the puncture was typically made "6 m.m. outside the corneoscleral margin", slightly inferiorly (e.g., at 4 o'clock for the right eye), but that he had observed "marked variations", and, as a result, he had observed damage to the ciliary body (143). In 1910, Ekambaram observed a Muslim oculist in Somanur (Tamil Nadu) make the puncture "about $8 \mathrm{~m} . \mathrm{m}$. outwards from the cornea and about $2 \mathrm{~m} . \mathrm{m}$. below the horizontal meridian" (84). We also see some variation in the site of scleral puncture in the ancient and medieval texts. Throughout history, scholars who attempted to estimate the distance at which healers were making the scleral puncture might observe a wide range of values.

Moreover, it is conceivable that Suśruta meant that the distance from the limbus to the puncture site was twothirds of some other distance. Other candidates would be the barleycorn or the width of the instrument. Indeed, in the historical ophthalmic works, there is an interesting confluence of 3 distance measurements: the thickness of the couching instrument, the distance from the limbus, and the barleycorn. As noted above, Suśruta compared the tip of the couching instrument to a grain of barley. Paulus Aegineta specified the puncture to be made at the width of the handle of the cataract instrument (79). Khalifah specified the puncture to be made "as wide as the end of the handle of the cataract needle, which is one barleycorn wide" (79). As noted above, Ammar of Cairo instructed to "open the conjunctiva at the lateral canthus at the same spot as is used for paracentesis. This spot should be < distant $>$ two thirds of a barley-corn from the black part (limbus)." (79). In addition, the barleycorn was a frequent unit of measure 

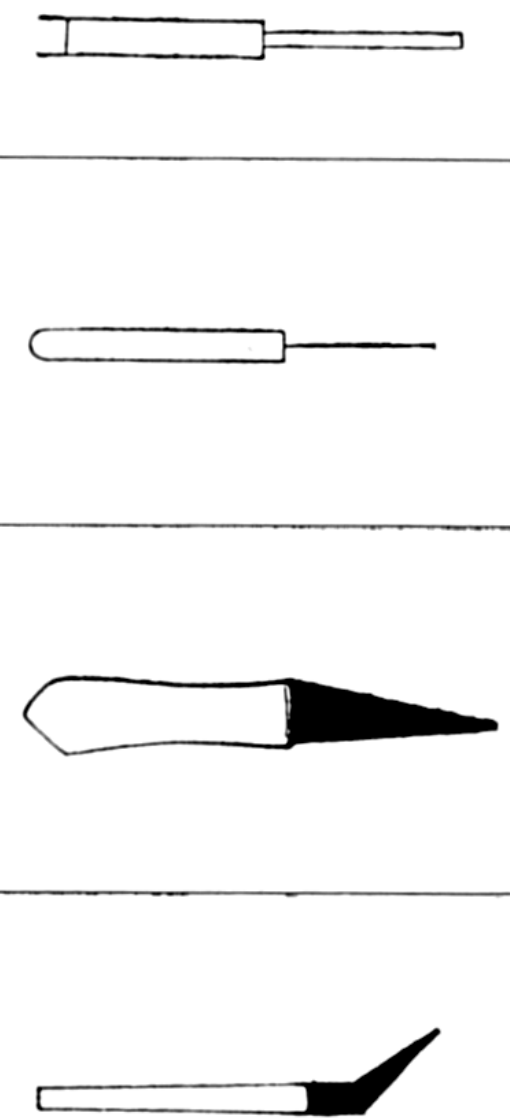

Figure 15 Ophthalmic instruments in Khalifah's treatise (1266 $\mathrm{CE}$ ), as illustrated in the Parisian manuscript (1273 CE). Khalifah described: [top]: "Hollow cataract needle (mibatt mujawwaf). To aspirate a cataract. This operation is well known, but God knows it best." [2 $2^{\text {nd }}$ from top]: "The round cataract needle (mibatt mudawwar)... It can be interchanged with the triangular needle [not pictured]." [ $2^{\text {nd }}$ from bottom]: "a thorn knife (sikkin). With this instrument we incise the frontal arteries." [bottom]: "A small knife for the sty (dhāt al-shu 'irah). A lancet, the length of the blade is that of a corn of barley; also used to incise the conjunctiva for a cataract operation".

for the oculists throughout the cataract procedure. Khalifah had "a lancet, the length of the blade is that of a corn of barley...also used to incise the conjunctiva for a cataract operation." (Figure 15) (54). Antyllus specified that during the cataract operation, "the needle should not be pushed beyond the pupillary margin, or at least no more than the size of a grain of barley" (54).
What distance did the barleycorn specify? In the ancient Indian measurement system, the finger's breath (angula), might nominally be assumed to be $19 \mathrm{~mm}$ (144). Moreover, the barleycorn (yava) was often defined as one-eighth of an angula, but sometimes as one-sixth or one-seventh (144). Thus, nominally, a barleycorn (yava) would typically be about $2.4 \mathrm{~mm}$. Actual barley kernels measure, on average, $5.9 \mathrm{~mm}$ long, $3.7 \mathrm{~mm}$ wide, and $2.9 \mathrm{~mm}$ high (thick) (145). These measurements were made with the husk on (Sarka Evzen, personal communication, 2020). Thus, the nominal system provides numbers lower than both the length and the width of true barleycorns. Hirschberg wrote that by one "barleycorn" oculists such as Ammar meant the actual width of one barleycorn (which Hirschberg specified as $4 \mathrm{~mm}$ ), because the length of the kernel was too variable as the shape was tapered and the fine tips were prone to breaking off (79). If oculists punctured the eye two-thirds of the dimensions of an actual barleycorn from the limbus, they would enter $2.5 \mathrm{~mm}$ (based on barleycorn width) or $3.9 \mathrm{~mm}$ (based on its length). The latter would probably work better. In any event, if imagining that he was making the puncture two-thirds of a "barleycorn" from the limbus worked for a dedicated oculist such as Ammar, it was probably a reasonable description for any comprehensive medical treatise, such as the Suśrutasambitā.

The expression "natural opening" (in 58cd-59ab) is found from time to time in the Āyurveda, and is also used, for example, in the Suśrutasambitāa (as well in the Aștāngasamgraba and the Aștāngahrdaya) in connection with piercing of ears. What is meant is not a real opening (a hole), but rather a place which is free from any kinds of ducts or vessels and thus appears as if naturally suitable for puncturing. In the case of piercing of an earlobe, a physician is asked to hold it against the sun to find such a spot. So, SS 1,16.3 uses exactly the same term "daivakrtachidra-".

As noted above, a scleral puncture two thirds of the distance from the limbus to the canthus is recommended in the works of Vāgbhața I and II. The Aștāngasaṃraba 6.17.7 says that one should pierce the eye at the "natural juncture" (netrasabajanmani sandhau) which is located, as noted above, at the intersection of two parts from the dark circle and one part from the outer canthus (krșnabhāgād bhāgadvayasyāpāñāād ekabhāgasya ca saṃgame).

Likewise, Aștānggahrdayasambitā $6.14 .11 \mathrm{~cd}$ specifies that one should pierce in the "natural opening" (daivachidra-) which is located one half finger away from the dark circle 
and one quarter finger away from the outer canthus (krșnād ardhān்ulam muktvā tathārdhārdham apānigatah). As noted above, one angula was defined as the width of a finger, nominally about $19 \mathrm{~mm}$ (144). Thus, Vāgbhața II assumes the total limbus-canthus distance to be about $14.25 \mathrm{~mm}$. We measured the average limbus-canthus distance to be $9.0 \mathrm{~mm}$ in people looking straight ahead, but higher values would be expected with convergence, as in the Indian works. Thus, Vāgbhața II recommends puncture at 19 * $1 / 2=9.5 \mathrm{~mm}$ from the limbus, i.e., posterior to the pars plana.

In these early Indian works, the instrument was a rod (śalākā). This word (śalākā) also described the rod used to apply añjana (collyrium) in the same texts (see above).

Beginning in the $2^{\text {nd }}$ century, in the Greek works (and their Arabic successors) this use of the primary instrument is preceded by applying to the eye a different instrument (or the opposite end of the primary instrument). The purposes proposed for use of the other instrument grow progressively more aggressive: to mark the site of the puncture, to acclimatize the patient to the touch, to make a small indentation in the conjunctiva where the primary rod will enter, and finally, with a lancet, to completely incise the sclera.

Antyllus wrote: "...then we mark a distance from the black (the limbus) which should be as wide as the end of the cataract needle... Then mark with the blunt end of a probe the site where you want to introduce the needle. This produces a depression and allows the point of the needle to enter without slipping." (6).

Paulus wrote: "...at the distance from the part called the iris towards the small canthus, of about the size of the knob of the specillum, we then with the point of the perforator mark the place about to be perforated...and turning round the point of the perforator, which is bent at its extremity, we push it strongly through the part which was marked out..." (56).

Avoidance of the blood vessels during surgery is found in both Indian and Mediterranean works. In general, avoidance of injury to the veins was considered the mark of a good surgeon in the Suśrutasambitā (SS 1.5.7) (101), as noted above. Likewise, Celsus advised that when making counter openings for missile removal, "no vein... nor an artery is cut" (7.5.1); when perforating dropsical patients "no blood vessel is cut into" (7.15.1); when advancing foreskin over the glans "great care is taken not to cut into...the blood vessels" (7.25.1); and finally, when incising an abscess under the tongue "no large blood vessel is cut into" (7.12.5) (102).

\section{Vision testing}

Antyllus recommended pushing the cataract down until the patient could see (67). However, Paulus Aegineta, specifically advised against early vision testing:

"...the bandages are to be kept on, if nothing prevent, until the seventh day, after which we loose them, and make a trial of the sight by presenting him with some object: but this we disapprove of during the operation and immediately after it, lest by the intense exertion the cataract reascend." (56).

The Indian authors were more enthusiastic. In Suśruta, "When the sights [possibly, colors or forms] are seen properly the śalākā should be removed slowly ..." (SS 6.17.65cd) (80).

According to Vāgbhata I:

"The eye thus cleared should be made to see (recognise) fingers, threads, close relatives, and his children... While the patient is thus observing things with his eyes open, the rod-like instrument should be taken out, rotating it all the time." (AS 6.17.9) (117).

Ibn Isa believed that the patch over the sound eye was useful so that "in testing recovered vision immediately after the operation one can be certain the patient is not looking with his sound eye." (126).

Albucasis in the $10^{\text {th }}$ century noted that "If the humour comes down at once, the patient will at once see whatever his vision is opened upon while the needle is still in his eye" (128).

In $20^{\text {th }}$ century Tibet, vision was tested just after removal of the needle (Figure 16) (91).

\section{Antyllus}

Much of the comparison of early Indian and Greek cataract surgery descriptions hinges on the works of a small number of authors. One such author who wrote in Greek was the surgeon Antyllus. His cataract surgery technique seems to overlap substantially with the Indian techniques: the sitting posture in the sun's shadow, having the patient look at his nose, having a wider portion of the shaft to avoid excessive entry, not patching the contralateral eye, and possibly placing cotton on the eye and blowing on the eye. Antyllus was known for recommending exercise, and for aneurysm, cataract, pterygia, and facial plastic surgeries $(146,147)$. Ibn Isa (84) and Ibn Sina (Avicenna) seem to have drawn on Antyllus' cataract method, which may not have survived to the present time in complete form. It is possible that 


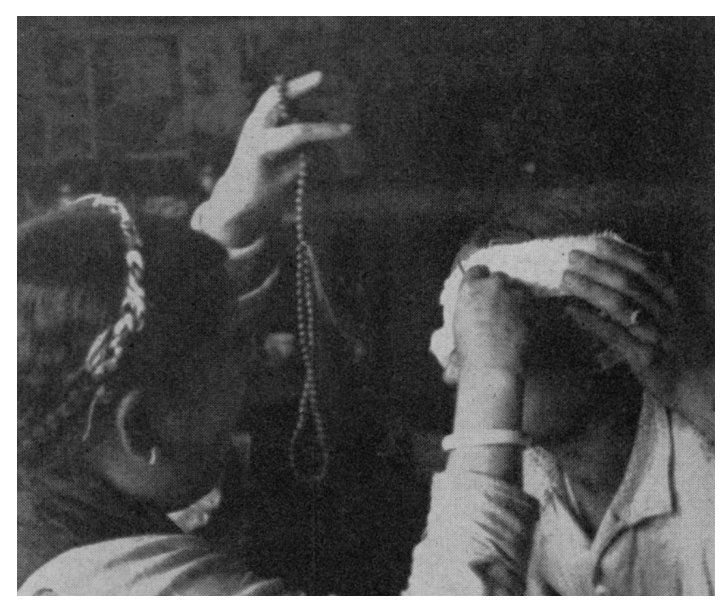

Figure 16 A Tibetan oculist tests vision just after couching a cataract.

other portions of these Arabic or Persian works which seem to overlap with the Indian authors may also have come through Antyllus.

We know little about Antyllus. Based on citations, he must have followed the early $2^{\text {nd }}$ century surgeon Archigenes, and must have preceded the $4^{\text {th }}$ century author Oribasius $(146,147)$. His biographer indicated that given his prominence, we might guess that Antyllus practiced in Rome (146,147). Meyerhof (84) placed Antyllus in Alexandria, but without providing a source. Given the possible Indian influences on his work, an eastern location within the Greek-speaking world, such as Alexandria, might be a reasonable guess.

\section{Greco-Roman ideas}

Certain ideas were found in the Greco-Roman works, and their Arabic successors, but did not appear in the early Asian works. To this list, we might add use of silver couching instruments and Antyllus' recommendation to use the same scleral puncture site if a repeat couching was required.

\section{Covering the nonoperative eye}

Whereas many Indo-Greek works emphasized looking at the nose, an alternate strategy was restricted in antiquity to the Greco-Roman works: not asking the patient to look anywhere particular, but covering the nonoperative eye. In Celsus, “...In order also that the eye to be treated may be held more still, wool is put over the opposite eye and bandaged on..." (7.7.14) (102). In Paulus, who cited Galen, "...we bind up carefully the sound eye" (56). Albucasis of the $10^{\text {th }}$ century (128), and Benevenutus Grassus of the $12^{\text {th }}$ or $13^{\text {th }}$ centuries continued this Mediterranean tradition of patching (or closing) the nonoperative eye without asking the patient to converge the eyes (148).

Ibn Isa combined the Mediterranean tradition of patching the sound eye with the Indo-Greek tradition of asking the patient to gaze at the nose (126).

This practice of contralateral patching spread eastward, perhaps with the medieval introduction of Islam into India, so that in Calcutta in 1824, Breton observed:

“...the Mahomedan oculist Sautcouree...placed his patient in a sitting posture on the ground, having previously bound over the sound eye a bandage to preclude objects from being seen, and thus preventing as much as possible motion of both eyes." (2).

Like Ibn Isa, this practitioner also had the patient gaze towards the nose.

The Greco-Roman practice of covering the nonoperative eye had arrived in Tibet by the $20^{\text {th }}$ century (Figure 16) (91).

\section{Entering an empty space}

One important concept in Greco-Roman ophthalmology which has figured prominently in $20^{\text {th }}$ century scholarship is that when the needle has entered the eye completely, one comes to an empty space. Celsus was explicit in clarifying that his purpose in noting this was to indicate that there was decreased scleral resistance. Paulus and pseudo-Galen also advised entry of the needle until it reached an empty space (141).

The Arabic authors also mentioned this empty space. For instance, Ibn Isa wrote that one would “...push the needle towards the opposite and corresponding part of the eye until you feel that you have reached a roomy space within the eye" (126). Ammar of Cairo wrote "When you now feel that the needle has now entered a wide space..." (79). Ibn Sina wrote that when passing the instrument "You will reach an empty place that is vestibule-like" (99).

Thus, the mention of the empty space was simply to alert the operator to expect decreased scleral resistance to the needle (as noted by Celsus) and to see the instrument in the pupil (as noted by Paulus Aegineta).

In 1901, the historian Hugo Magnus proposed that Celsus' mention of the empty space might suggest that, in contrast with Galen and Rufus, Celsus believed the lens to be in the center of the eye and could have inspired 
the medieval Arabic authors to accept this fallacy. In fact, there is no evidence that the medieval Arabic authors read Celsus. Moreover, Celsus' writings are consistent with the other Greek authors who mentioned the empty space entered during couching but still understood that the lens is anterior enough to touch the iris, and that the peripheral lens attaches close to the corneal limbus (Figure 10) (98). The fallacy of the central lens seems to have originated in medieval Baghdad, in the $9^{\text {th }}$ century writings of Hunain (141).

\section{Discission}

Discission (division) of the cataract is probably as old as couching, because some cataracts are too soft to be depressed, and simply break up. The Aștāngasamgraba recommended: "That liñganāśa which breaks/splits when touched by the śalāka (instrument) should be given fomentation by steamcooked leaves of eranda and cleaned..." (Aștāñgasaṃgraba 6.17.25) (117).

Intentional discission is found in the Greco-Roman works. Celsus wrote that the operator attempted discission if the cataract failed to remain depressed:

"if it returns to some extent, it is to be cut up with the same needle and separated into several pieces, which can be the more easily stowed away singly, and form smaller obstacles to vision." (102).

Galen wrote in Method of Medicine XIV:

"Apart from those, there are also some of them (I speak

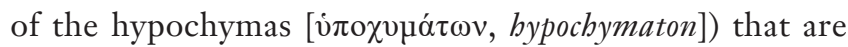
more wheylike than watery. Also, those that have been pierced on all sides are dissolved straightaway, although a short time later it is as if some slime passes off below." (Kühn 10.1019-20) (149).

We agree with those who believe this could represent discission (e.g., Lascaratos), though Hirschberg disputed this interpretation, and suggested that the piercing was just of the eye, rather than the lens capsule (6).

Ammar of Cairo recounted the case of a 30-year-old man with bilateral cataracts, the couching of one of which turned into a discission: "So I attacked the cataract with the needle vigorously. Behold, it had been cut to pieces like the membrane in an egg that encloses the white inside it." (79). Ammar wrote that the man could see afterwards (79).

Khalifah of $13^{\text {th }}$ century Aleppo advised:

"The cataract may create problems by rising again and again as soon as the pressure is slackened off. Then break the cataract up and disperse it in all directions, upwards and downwards, and towards both canthi." (79).

\section{Early cataract aspiration}

We live in an era of cataract aspiration, but some attempts to aspirate cataracts have been around since antiquity.

Antyllus' teachings regarding cataract surgery were preserved by Abu Bakr Muhammad Ibn Zakariya alRazi (known in Latin as Rhazes, circa 865-925) in his encyclopedia Kitab al-Hawi fi al-tibb, known in translation as Liber Continens. Meyerhof translated from the Arabic of the Escorial manuscript as well as a manuscript in his private collection:

"Antyllus says: Certain doctors have made an incision in the lower part of the pupil (cornea) and extracted the cataract. He continues: That is good in cases of thin (soft) cataract, but not in cases of thick (hard) cataract, because the albuminoid humour (aqueous humour and vitreous body) escape. Others have introduced a glass tube by the paracentesis opening and have proceeded by aspiration, drawing in the cataract with the albuminoid humour." (150).

Several finely crafted hollow needles, potentially suitable for cataract surgery, have been found at Montbellet, France, dating from about $100 \mathrm{CE}$, and at Villa dels Tolegassos, Viladamat, Girona, Spain, dating from about 200 CE (Figure 5) $(67,151)$.

That the Persian author Zarrin-Dast (Goldhand) in 1087/8 CE would attribute cataract surgery with the hollow needle to the Greeks and Romans (54) is consistent with original attribution of the method to Antyllus.

Multiple Arabic authors were aware of the operation to aspirate cataracts, and some of them illustrated the hollow needle (Figure 15) (54). Albucasis in the $10^{\text {th }}$ century wrote "I have heard that a certain Iraqi has said that in Iraq he makes a hollow needle by which the humour is sucked out. In our land, I have never seen anyone do it in this fashion..." (128). The medieval oculist Ammar of Mosul, who practiced in Cairo, manufactured a hollow needle for cataract aspiration. He recounted that he used it first on a Christian in Tiberias: "I then operated on him with the hollow needle and extracted the cataract.... Nobody has preceded me in the use of this needle...I, however, have already operated on many patients with it in Egypt." (79).

Ammar's development of the hollow cataract needle was later recounted by Ṣalāh al-Dīn al-Kahhạāl in the $13^{\text {th }}$ century (79). Șalāḥ al-Dīn explained that Thābit Ibn Qurrah disapproved of the operation with the hollow needle on the grounds that the cataract was covered with a capsule which 
was hard to penetrate, and that the healthy fluid of the eye would also be aspirated (79). Șalāh al-Dīn thought a bronze tube would work better than the glass tube recommended by Antyllus (79).

The $14^{\text {th }}$ century Egyptian oculist Sadaqah ibn Ibrahim al-Shadhili described seeing in the market hollow cataract needles, which were supposed to work either by oral suction or by turning a screw. He was skeptical of their efficacy for a variety of reasons. al-Shadhili had heard of the hollow cataract needle being in the instrument set of a Russian and of a Turkmen in both Russia and in the Roman (Byzantine) empire. The relevant passages from al-Shadhili's Arabic manuscript have recently been translated into English (152).

The modern revival of cataract aspiration is discussed below.

\section{Evacuation of cataract or hypopyon?}

Some passages appear to indicate that cataract extraction by an inferior corneal incision might have been performed in antiquity when the cataract was particularly fluid. As noted above, Antyllus mentioned that some doctors cut the inferior cornea to drain soft cataracts, but this method could be complicated by accidental drainage of the normal proteinaceous fluid (presumably aqueous).

One passage of Galen in Method of Medicine XIV has been interpreted by Lascaratos (153) to allude to cataract extraction:

"...whenever the affection is incurable, it [the best treatment] is to cut out the part together with the affection, as in the case of a cancer and all untreatable ulcers. Contrariwise, having abandoned the first indicator, as in the

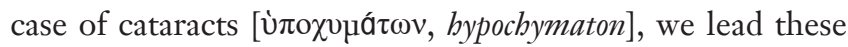
things to another, less important place. Some [doctors], however, also attempt to evacuate these things, as I shall speak of in the [writings] on surgery." (Kühn 10.987) (149).

Note that neither Antyllus nor Galen suggests that he has seen the method successfully performed.

In addition, it is hard to be sure about the condition being treated. In the ancient and medieval periods, cataract couching was believed to displace a concretion forming anterior to the lens. Thus, occasional discussions of removing a fluid cataract by an inferior corneal incision might actually have been cases of hypopyon drainage. Indeed, in Method of Medicine XIV, Galen did describe drainage of hypopyon by an inferior corneal incision:

"Often, I evacuated the pus all together, having divided the external coat of the eye just above the tunic at the place where all the tunics grow together with each other. Some call the place the 'iris', others the 'crown." (Kühn 10.1020) (149).

In Galen's works, the iris or crown of the eye was the limbus (141).

Proponents of the notion that cataract extraction was attempted in antiquity would argue that Galen and Antyllus knew the difference clinically between hypopyon and bypochyma (even if they did not understand a bypochyma to be an opacity of the lens). On the other hand, with the universally high level of misunderstanding regarding bypochyma pathophysiology in the ancient and medieval worlds, it is difficult to exclude the possibility that the unnamed doctors who attempted the procedure were actually draining a hypopyon. Hirschberg wrote: "Did the Greeks confuse a cataract with pus, hypochyma with hypopyon? Probably only those with an insufficient medical knowledge." (54). And so we are left to wonder if the unnamed surgeons who attempted to extract the bypochyma were more like Galen, or whether they had "insufficient medical knowledge".

Medieval oculists restricted themselves to repeating the line about extraction from Antyllus. For instance, Ibn Sina (Avicenna) wrote: "Some eye surgeons have their own way. They cut underneath the cornea and have the water drip out, but this is dangerous because if the water is thicker than it is supposed to be, it will bring out the moisture of the aqueous humor with itself." (99).

We know from the early era of cataract extraction that sometimes when the inferior corneal cut was made, the unanesthetized patient would squeeze the eye shut so hard that the lens would spontaneously be expressed from the eye (13). However, this occurrence was exceptional. Typically, the surgeon had to either make a capsulorrhexis (for extracapsular extraction), or impale the lens or apply pressure to the eye (for intracapsular extraction). However, as we outlined above, the brief ancient and medieval allusions to cataract extraction by a limbal corneal incision do not mention these extra steps required to actually extract the cataract from the eye. This lack of detail argues in favor of these actually referring to hypopyon drainage.

Even when a cataract happened to accidentally sublux into the anterior chamber during couching, the medieval Arabic oculists did not attempt to extract it. For instance, Ammar of Cairo couched a 20-year-old man from Persia with bilateral cataracts. With the left eye "the cataract had emerged from the pupil, lay opposite to the cornea and stuck there between the cornea and the outer surface of the 
iris." (79). Rather than extract the cataract with an inferior corneal incision, Ammar simply dressed the eye and found on the third day that the cataract had disappeared and the man saw fine with this eye (79).

The case outlined below in which the $13^{\text {th }}$ century oculist of Aleppo named Khalifah Al-Halabi asked the patient to breathe in deeply to help the cataract remain depressed was actually complicated forty days postoperatively by subluxation of the cataract into the anterior chamber. However, Khalifah's detailed case report does not end with him extracting the cataract (79).

\section{Indo-Arabic ideas}

The Arabic works were most strongly influenced by the Greek texts, and the Arabic authors explicitly cited these Greek authors. Nonetheless, some ideas about cataract surgery are common to Arabic and Indian works, but not well-established in Greco-Roman works. There are a few possible explanations. One is that the ideas were found in prior Greek or Syriac works which have been lost. Another possibility, probably the most conventional approach, is that the ideas spread from India to the Arabic-speaking regions, primarily with translation of the texts. We must also consider the possibility of oral transmission from travelers between India and Persia or Mesopotamia. The most radical approach would be to propose very late dates for the Indian works, which then could have been modified by the ideas from the Arabic authors.

Ibn Isa's work seems to be the first to adopt many Indian ideas not found in prior Greco-Roman works: operating at the proper season, reassuring the patient, proper control of the patient's breathing, and restraining the patient's limbs (as opposed to just the head). Why ibn Isa explicitly cited the Greek but not the Indian works is unknown. Perhaps, his knowledge of the Indian techniques came from oral teachings from knowledgeable oculists, as opposed to written texts. Alternatively, perhaps he thought the Greek works would be held in higher esteem by his readers.

Analysis of the Indo-Arabic ideas is confounded by the fact that even if the Arabic works did not arrive in India in time to influence the works of Susruta or Vagbhata, it is known that after Islam entered India, these Arabic works and the practices of Islamic oculists did become established in India. For instance, in the $16^{\text {th }}$ or $17^{\text {th }}$ century in Hydberabad, an oculist named Shamsuddin Ali Husain al-Jurjani translated Tazkirat-ul-Kabbalin (Notebook of the Oculists) by 'Ali bin 'Isa into the local language on the orders of his master Muhammad Quli Qutub Shah (154).

\section{Proper season}

According to the Suśrutasambitā, cataract surgery should be performed "... in a season which is neither too hot nor too cold." (SS $6.17 .57 \mathrm{~b}$, see above). The $64^{\text {th }}$ chapter of the Uttaratantra in the Suśrutasambitā has a great deal on the effect of season on various diseases (80). Season was generally important in Greco-Roman medicine as well, and it would not be surprising if a written record of its importance in relation to cataract surgery simply did not survive up to the present time.

As noted above, ibn Isa advised performing cataract surgery in summer (126). Șalāh al-Dīn al-Kaḥhāal of $13^{\text {th }}$ century Hama, Syria advised operating at "the autumnal or spring equinox" (79).

\section{Restraining the limbs}

In the Suśrutasambitā, in preparation for surgery: “... the patient should be positioned and held firmly ..." (80).

Vāgbhata essentially secured the limbs by having the surgeon sit on a stool on top of the patient's legs, as noted above.

As noted above, ibn Isa advised tying both the hands and legs of the patient (126).

\section{Reassuring the patient}

Vāgbhata I reassured the patient while the needle was still in the eye (before moving it towards the middle of the pupil).

"[While the rod is in the eye]...encouraging/assuring the patient ... [Postoperatively, the patient is] kept happy by telling him pleasant stories." (AS 6.17.9 and 10) (117).

Likewise, ibn Isa wrote that while the needle was in the eye: "At this stage of the performance tell the sufferer to be of good cheer, and encourage him not to worry because all will be well." (126).

\section{Wider needle}

In order to penetrate the eye without excessive trauma, the initial instrument must be at least somewhat sharp, whether it ends in a point or a blade. The Greco-Romans had used couching needles that ended in a point, and some medieval Arabic authors continued this practice (Figure 15) (54). 


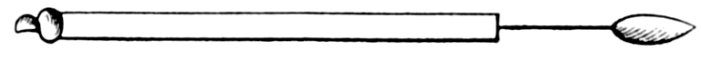

Figure 17 The surgical treatise of Abū al-Qāsim (Albucasis) contains an original illustration of a cataract needle (mihatt), which has a leaf-shaped incisional end.

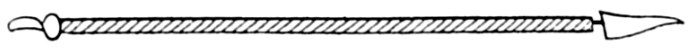

Figure 18 The anonymous manuscript Escorial 876 illustrates in volume 87 a cataract needle (miqdah) with a triangular point. The manuscript specified that the handle be serrated to permit rotation during the surgery.

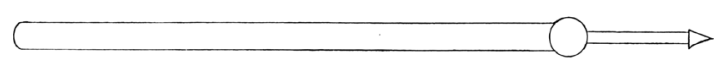

Figure 19 A triangular cataract needle is found in the Parisian manuscript (suppl. Arabe No. 1042) of Șalah Al-Dīn's "Light of the Eyes".

Hunain of $9^{\text {th }}$ century Baghdad translated the Greek authors, and simply described piercing the eye with a needle "at the extremity of the eye in the outer corner", taking care not to "reach the back of the uvea [the iris] from inside and tearing it" (155). No preoperative marking was specified.

In contrast, the ancient Indians used a salaka (rod) with a tip which presumably was wider, as it was compared to a grain of barley. Likewise, after Hunain, some medieval oculists used needles depicted in the Arabic manuscripts as being wider, resembling in some cases the renditions of the barley-tipped salaka (Figure 17) (54), but in other cases being triangular in shape (Figures 18,19) (54). For instance, Ibn Isa specified a triangle-shaped needle. It is conceivable that these wider needles reflected influence from Indian oculists.

\section{Placing cotton and blowing on the eye}

Placing cotton on the eye and blowing on the eye are often found in the same Indo-Arabic works, and possibly also in the Greek writings of Antyllus. Blowing on the eye was also practiced by indigenous New World healers (4), and is probably many thousands of years old. Use of cotton has a long history by the inhabitants along the greater Indus Valley region (156).

In the Indian works, blowing on the eye and placing cotton on it were both performed during cataract surgery, but not at the same time. Vāgbhata I blew on the eye preoperatively:

"...blow warm air on the eye" (Aștāngasamgraha 6.17.7) (117).

In India, "fomenting" the eye with heat was held to be beneficial from antiquity up to the modern period.

Cotton was applied after the procedure, similar to how we place a patch today:

"...a swab of cotton soaked in comfortable warm ghee is placed on the eye and the bandage applied..."-Vāgbhața I, (Asțāngasamgraha 6.17.10) (117).

In a number of Arabic works, the two practices occur in conjunction. For instance, Ibn Isa put cotton on the eye and then blew on the cotton not once, but twice. The first time was to preoperatively assess the maturity of the cataract by:

"...laying a cotton-wool pad over the eye to be observed and blowing on it forcibly with one's own hot breath. Then examine the eye uncovered; if the cataract appears to move and seems clear, it is an indication for operation." (126).

Ibn Isa repeated the practice while the needle was in the eye:

"The eye that is being operated on should at this stage be covered with a layer of fresh cotton wool on which you should audibly blow warm breaths of air and make sounds like drinking, as if to relieve the unrest of the eye." (126).

Blowing while the couching instrument was in the eye was still practiced in Tibet in the $20^{\text {th }}$ century (Figure 20) (91). Ibn Sina (Avicenna) repeated Ibn Isa's test of maturity by placing cotton on the eye and blowing on it (99).

Greek sources (as Indian) would deliver medicines by blowing them (6) But to treat a disorder just by blowing on the eye was more consistent with traditional Indian medicine. Suśruta noted (157) that "...in case of minute foreign bodies in sense organs, it should be cleaned with washing and blowing and with hairs (brush), cloth and hands..." (101). For a traumatized eye, Suśruta (SS 6.19.5) recommended: "The injured eye becomes painless on fomenting it slightly with mouth-vapour" (80).

In this context, we can analyze the Greek writings of Antyllus, which come to us from the Arabic writings of alRazi, and its Latin translation, the Continens of Rhazes. The Latin Continens provides Antyllus' method, in which the operator blows on the eye with the needle in place. According to Hirschberg's translation: 


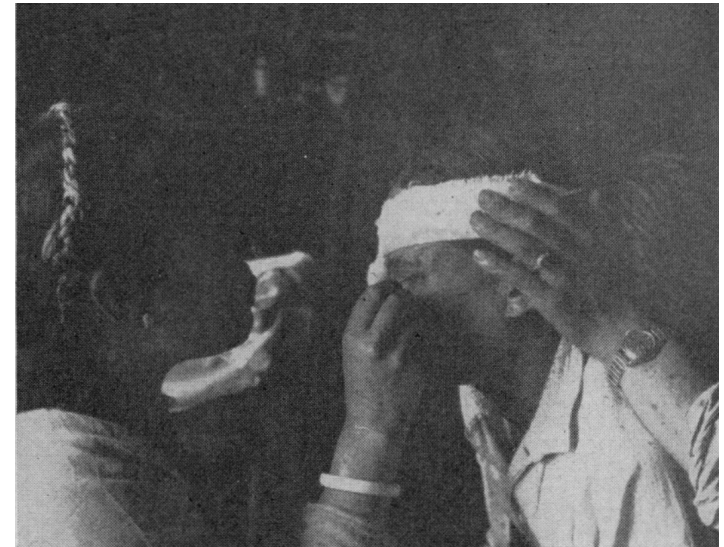

Figure 20 A Tibetan oculist performing couching blows on the eye while the needle is embedded in the eye. The contralateral eye is covered.

"When the needle is now in the eye come closer with your mouth and then blow onto the eye of the patient so that the pupil remains regular." (54).

Others agree that the Latin Continens indicates blowing on the eye (67). Hirschberg also read Antyllus in the (Escorial manuscript) Arabic of al-Razi to recommend blowing on the eye at this stage (6). However, Meyerhof (86) and Feugere (67) read the Escorial manuscript to have Antyllus recommend placing the mouth on the eye and sucking until the pupil becomes normal (round). Alternatively, the Arabic manuscripts used for the Indian edition of al-Razi recommend placing a piece of cotton on the eye (67). These variant readings of Antyllus (blowing, sucking, placing cotton) must be interpreted in light of the later writings of Ibn Isa and Avicenna, in which placing cotton on the eye and blowing are performed in conjunction. We agree with Meyerhof, who believed that much of Ibn Isa's cataract surgery method was drawn from Antyllus (86). Indeed, Antyllus recommended that for a repeat couching, one used the same scleral puncture site, because it did not close up quickly $(67,86)$. The same idea is found in Ibn Isa (126) and Ibn Sina (99), but is not found in Celsus or the Indian works. With this close connection between the works of Antyllus, Ibn Isa, and Ibn Sina, and the available readings of Antyllus, it seems likely that Antyllus did recommend placing cotton on the eye and blowing on the eye. (Perhaps, the sucking recommended by Antyllus corresponds with Ibn Isa's "make sounds like drinking"). As described by Breton (2), simultaneous fomentation of the eye and placment of cotton near the eye, both while the probe was still embedded, survived in India into the $19^{\text {th }}$ century.

Blowing on the eye and using cotton are better established in the Indian medical works than in the Mediterranean works. If these practices are considered Indo-Greek (rather than just Indo-Arabic), then they are consistent with an Indian origin for cataract surgery.

\section{Control of breathing}

One feature of Indo-Arabic cataract couching has played an outsized role in the recent literature. Special control of breathing of the patient is encouraged in the middle of the couching procedure, or occasionally just afterwards. In fact, this breathing is typically performed while the couching rod is still in the eye. These breathing techniques have long been noted by commentators and have traditionally been considered consistent with couching.

All translations of the Suśrutasampitā agree that during the breathing maneuver, the patient closes the contralateral nostril, and the couching needle remains in the eye, lodged in the puncture site. Several recent authors have used the word "blow" to describe the patient's breathing technique in the Suśrutasambitāa $(80,158)$, and have proposed that perhaps the work describes a Valsalva maneuver, with the intent of expelling the lens, while the couching instrument was lodged in the puncture site (159). However, both of the above translations rightly translate SS 6.17.65 to indicate that the "dosa" which previously was eliminated can "reappear", in which case the puncturing procedure is repeated $(80,158)$. The only way the surgeon could know if the "doșa" had reappeared is if it represented something visible to the doctor's eye-namely the opacity in the visual axis. The apparent disappearance of an opacity, followed by its reappearance, might reflect temporary movement out of the pupil (into the vitreous or behind the iris), followed by a return to its original pupillary position.

In contrast, other translations have been consistent with the idea that Suśruta described inhalation: "by snorting" (160), "to sniff" (161), "to inhale" (140), "to snuff" (100), "suck" (6), "drawing up into the nose" (162), "to sniff and snore and draw in phlegm from the nasal sinuses into his throat" (163) (see Supplementary 2).

None of the prior translations has analyzed the relevant Sanskrit. The word related to breathing in the couching descriptions of both Suśruta and Vāgbhața is ucchinghana-, which could be contextually translated as "to inhale forcefully". In the case of Suśruta, the specific 
form is ucchingbanena, which is the instrumental singular of ucchinghana- (Su, Utt., 17, 64.1) (127). The word ucchinghana can be separated into two main morphological elements $u t+$ śingbana-, where $u t$ - is a prefix, which means something like "up", and "śinghana-" is an action noun derived from the verbal root لíingh (or, more correctly, لvíighi), which means "to smell (to suck air)". The combination $u t+$ singh becomes ucchingh- (due to regular phonetic changes) and means, therefore, "to suck up the air/ to snort up".

Various derivatives of this verb (as well as of its phonetic variant $u c$-chink $k$ ) are often used in āyurvedic literature, in the meaning "to snort up" (that is, to inhale forcefully in order later to spit out). Most typically, it is used in the context of nasya therapy (application of medication through the nose), where the patient, after a light massage, is asked to snort up the medicine slowly and to spit out the mucus etc., along with which one usually tries to evacuate kapha (evacuated mucus, in fact, can be seen as a certain manifestation of kapha, i.e., kapha in the form of an excretory product). See, for example, AS 1.29.16 (śanaiś cocchinkbet) and AHS 1.20.20c (śanair ucchidya nișthivet, which is almost certainly a mistake for śanair ucchinghya nisthivet). In a similar context, a derivative of the same verbal complex can be found in Suśrutasambitā 4.40.53ab (ịsad ucchinghatah sneho ...).

The Suśrutasaṃbitā (6.19.8ab) recommends ucchinghana after trauma producing "a hanging eye" - the patient should adopt "forceful inspiration" (80). Clearly, a Valsalva maneuver in this circumstance would make proptosis worse.

Thus, the Suśrutasaṃbitā (SS 6.17.63cd—64ab) instructs that the patient should first close the nostril opposite to the treated eye. Second, he should snort up (through the nostril on the same side as the treated eye) and in this way remove kapha.

The recent ophthalmology literature implies that the special breathing technique was unique to the Suśrutasambitā. In fact, this specific breathing technique ucchingbana- was also recommended by Vāgbhața I and II. For instance, the Aștāingahrdayasambitā (AHS $6.14 .15 \mathrm{~cd}$ ) in the corresponding verse with the couching needle in the eye uses the expression ucchinghanāc cāpahared, which includes the component term ucchinghana (to inhale forcefully). This passage ("ucchinghanāc cāpahared drșțimaṇalagam kapham") translates as: "By means of ucchinghana- (snorting up / sniffing) he should remove kapha located in the circle of the drsțti (pupil)".

Indeed, the understanding of ucchingbana as inhalation has been reflected in some prior translations of this work. For instance, J. Jolly translated this passage in the Aștāñngahrdayasaṃhitā as:

"He then scratches with the point of the lancet the pupil without hurting the patient. He then slowly pushes the mucus toward the nose where the patient should suck it into his nose." (6).

Similarly, the corresponding passages in the Aștāngasamgraba (6.17.9-10) also contain this specific breathing technique:

“...rāgāśrruvedanānutpādanārtham ca stanyena secayet I

tataḥ punar āturam āśvāsya bbramayan śalākām ā drștimadhyāt praveśayet | | 17.9

... (one punctures the eye as above, hears sound and sees drop of whatever if all went well, and then one just keeps the needle steady for a moment)...

...He should sprinkle the eye with breastmilk, so that there will be no redness, tears or pain.

Then again, having comforted the patient, [the doctor] moving the needle to and fro, should bring it to the middle of the pupil.

adhaś cāsyāvalokayato linganāśam adrutam avilambitam anusukham adhomukbam apanayed ucchinkhayec cainam I

tathā hi dṛk srastakaphasya viśudhyati ।

viśuddhadrșțeś cānguliṃ tantūn jñātīn santatīịś ca darśayet I... 17.10

And then, neither slow nor fast, in an agreeable way, while the patient is looking downwards, [the doctor] should remove the linganāśa- downwards and ask him [the patient] to snort up. Because in this way the eye (or pupil) of [the patient whose] kapha- is sunk down becomes clear. [The doctor] should show [to the patient whose] eye / pupil is now clear a finger, threads, relatives and friends..."

Postoperatively, Vāgbhața I in the Aștāingasamgraba recommended for the opacity (linganāśa) which returned to the visual axis:

"When it is found floating up, the treatments are frightening (the patient), by sprinkling/splashing cold water, hard/forceful inhaling constantly." (AS 6.17.13) (117).

Here, the breathing was inhalation, and was intended to help when the opacity was "floating up", which was wellknown to occur in some instances when a lens depressed into the vitreous returned to the visual axis.

As we have noted, these early Indian works might have influenced the Arabic eye surgeons. Hirschberg believed that the question of the purpose of the breathing techniques during couching could be best studied by examining all of the relevant ancient and medieval literature, and even 
the modern eyewitness accounts of traditional healers. Indeed, special breathing techniques are prescribed in multiple Indo-Arabic accounts, all of which have long been understood and witnessed to represent cataract couching.

When we look at the Indo-Arabic works as a whole, several hypotheses for the breathing techniques during or just after couching have been, or could be, proposed:

(I) Expulsion of the lens from the eye, either in whole (159), or in part (160).

(II) Some early couchers wrote that these breathing techniques assist in displacing from the visual axis any opacities which had floated there from the vitreous (see below). This belief might have motivated their actions, regardless of whether the breathing techniques were actually helpful in this regard.

(III) Hirschberg proposed that the breathing techniques to move nasal mucous of the Indian couchers related to their humoral theories, with phlegm as the basis of the opacity.

(IV) To distract the patient from his pain and fear, and to encourage the same types of relaxation as nostrilbreathing does in yoga.

(V) As with many rituals, such as blowing on the eye, there could be a placebo effect.

One must give all explanations due consideration, given that our searches have not revealed accounts of a traditional healer enabling a patient to expel the lens, in whole or in part, while the couching rod was still lodged in the sclera through a pars plana puncture. We do not mean to imply that each rationale applies equally to all authors.

Hirschberg explained his understanding that: "the couching itself is attributed more to the patient who by breathing heavily dislocates the cataract... The drawing up of the mucus into the nose is an action which can be explained by the humoral pathologic theories of that time and with which we have to content ourselves." (6). He also wrote: "The heavy breathing of the patient is here only an auxiliary activity." (6).

Hirschberg's idea of a theoretical humoral basis for the breathing techniques corresponds with the passage of Celsus above which noted that cataract (bypochysis) in its early stages could be treated by bringing out phlegm by gargling, or inhaling smoke, in order to make the phlegm thin.

Several Arabic oculists declared that certain breathing techniques would assist in keeping the cataract depressed. The medieval Arabic oculist Ibn Isa advised:
"Instruct the patient, if during the operation he must clear his throat or nose, to hawk down the former and not to blow his nose in the usual way as the former manoeuver will assist you to push the cataract downwards." (126).

Perhaps an occasional oculist would have a patient exhale. Ammar of Cairo, who explained that exhalation moved the cataract out of the visual axis:

"If the cataract stays in the ciliary processes, tell the patient to cough, blow his nose, and grind his teeth-all this while the needle still remains in his eye, and the eye remains closed. Then tell him to open his eye. If the cataract has returned and ascended, guide the needle on to the cataract again..." (79).

Ammar gave very detailed case histories of couching, discission, and aspiration of the cataract by a tube. If this exhalation maneuver had resulted in extrusion of significant portions of the cataract, Ammar would almost certainly have mentioned it. His failure to mention such extrusion casts doubt on whether it is even physically possible to extrude significant portions of a cataract by exhaling while a couching needle is lodged in the pars plana.

The oculist Khalifah Al-Halabi of $13^{\text {th }}$ century Aleppo explained his thinking with one particular patient in The Book of Sufficient Knowledge in Ophthalmology:

"When I operated, I got tired by the repeatedly rising cataract. So, I put a weight on the patient's head using a mortar, while he helped me by breathing in deeply through his nose. From this moment on the operation was successful." (79).

Khalifah amplified these remarks more generally with respect to all cataract couching:

"Ask the patient to help you by breathing in through his mouth, not through his nose. This helps to depress the cataract. Once the cataract is depressed, gradually withdraw the needle with a rotary motion." (79).

Likewise, Ṣalāḥ al-Dīn al-Kaḥhāl of $13^{\text {th }}$ century Hama, Syria advised that while one has the couching needle in the eye "Then ask the patient to breathe heavily - through the mouth and not through the nose-so that the cataract will be pulled downward." (79).

In 1826, Dr. Peter Breton described the couching technique of a Muslim practitioner in Calcutta. While the needle was still in the eye, the patient was "directed to draw in his breath several times forcibly through his nose" which would "cause the lens to be forced downwards, and drawn into the interior part of the eye out of the sphere of vision." (2).

In 1894, T. M. Shah, a surgeon at Junagadh State 
Hospital in Kathiawar related the technique of a local Muslim couching practitioner ("bakeem") in East India:

"The three-edged portion of the probe is then thrust into the wound towards the vitreous and left hanging for a moment. The patient is then told to take a few deep inspirations." (164).

If Shah was correct that the inspirations occurred immediately after entry of the probe into the vitreous, and before an initial attempt at depression of the lens, then presumably the purpose would be to relax the patient who had just had a probe thrust into his unanesthetized eye. Of note, the initial opening was created not with the probe, as in the oldest works (Suśruta and Celsus). Rather, this practitioner used the medieval Arabic method of an initial incision with a lancet: "With this free point of the lancet a cut is made below and a little outwards into the sclerotic about two lines from the corneal margin" (164). It might be supposed that this larger incision would facilitate expulsion of the intraocular contents. Still, Shah never observed anything coming out of the eye with the instruments in place (including during the breathing maneuver). However, he did note that "Sometimes a little vitreous dribbles on the withdrawal of the probe" (164).

\section{Medieval ideas}

\section{Zarrin-Dast (Goldhand)}

The Persian ophthalmic treatise from 1087/8 CE entitled Light of the Eyes or Nūr Al-'Uyūn was written by Abū Rūh Muhammad Ibn Manșūr Ibn Abi 'Abdallāh ibn Manșūr Al-Yamānī (or Al-Gurgānī), who appended the surname Zarrin-Dast (Goldhand). His work provides an interesting overview of the origination of surgical techniques present in the Middle Ages. Zarrin-Dast's full name suggested that he may have been from Gorgan, close to the Caspian Sea (54). He complained that in his time "fools and women practiced ophthalmology and without learning the subject" and damaged the vision of many patients (54). Zarrin-Dast cited the ophthalmic works of Galen, Hunain, Ibn Māsawayh, and Al-Rāzi (54). His promise to present eye operations in a simplified manner and his own observations suggest that he was personally familiar with eye surgery (54). His treatise apparently did not cite any Indian works, but it is the earliest surviving work from west of India to confirm that cataract surgery was taking place in India.

Zarrin-Dast wrote that: "The cataract incision can be made in three ways: (I) with a small knife (and the cataract needle), (II) with a solid needle alone, (III) with the hollow needle." (54). He attributed the method of the solid needle to the Indians, the method of the hollow needle to the Greeks and Romans (Yünānī, and Rumi), and the method of the knife to the Baghdad surgeons (54). Hirschberg thought that Zarrin-Dast was in error (54). First, Hirschberg believed that cataract aspiration in the Middle Ages was better associated with the Baghdad surgeons (54). Second, Hirschberg assumed that cataract surgery in ancient India must have been performed in the manner of the oculists observed in India in the $19^{\text {th }}$ century-beginning with an incision by a lancet. Hirschberg did not appreciate that the two-instrument lancet-needle technique had been imported along with the medieval Islamic conquest of portions of India. After reviewing a translation of the Așțāngahṛdayasaṃhitā by Vāgbhața II, Hirschberg wrote: "In this text I miss the allusion to two different instruments. This text is rather short and probably requires an oral explanation by the teacher." (54). Even though Vāgbhatạ's text described surgery with just one instrument, Hirschberg insisted that two were used! The mistake that the twoinstrument (lancet-needle) technique of the couchers in $19^{\text {th }}$ century India must also have been practiced in antiquity has been made by others, both before and after Hirschberg $(162,165)$.

Returning to the text of Zarrin-Dast, if we look at his attributions as being statements about the initial origin of each technique, he could have been correct on all three counts. Zarrin-Dast was indicating that the solid-needle cataract surgery described by Celsus and Suśruta originated in India. Cataract aspiration was described by Antyllus in the Greek areas of the Roman empire. Greco-Roman performance of this technique might also be supported by the ancient hollow needles found in France and Spain (which were unknown in Hirschberg's time) (Figure 5) $(67,151)$. Cataract surgery with the lancet originated in medieval Baghdad (as we discuss below). It is interesting that a knowledgeable medieval oculist located between India and the Mediterranean would attribute to the Indians the earliest cataract surgery described-the method with the solid-needle.

\section{The lancet}

Although many of the Indo-Arabic ideas started in India and diffused westward, use of the lancet to make an initial incision when couching began in the medieval Arabic caliphates and diffused eastward into India (Figure 8). 

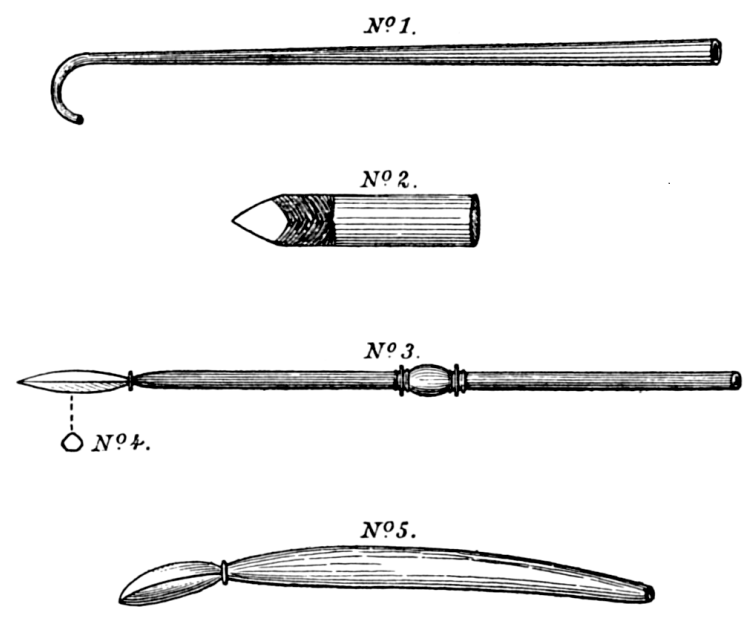

Figure 21 Copper couching instruments acquired in India by $\mathrm{H}$. E. Drake-Brockman, covered with twisted cotton. 1, Hook for elevating the lid. 2, Lancet wrapped with cotton thread. 3, Cataract couching needle from Mirzapur. 4, Cross-section of the point from (3). 5, Cataract couching needle from Punjab.

Hirschberg found that whereas the words for most ophthalmic surgical tools in the Arabic works were Arabic in origin, the word for lancet, al-barìd, was derived from Persian (54). As noted above, in 1087/8 CE, the Persian Zarrin-Dast attributed to the Baghdad oculists cataract surgery with incision by a lancet followed by the needle (54).

Indeed, Ali Ibn Isa, of Baghdad (ca. 940-1010 CE) marked the puncture site as Paulus did, but apparently a bit more aggressively, so that an actual puncture could be made while marking. In addition, the couching needle subsequently used to depress the cataract had a triangular tip, rather than a rounded end:

"Then measure with the end of the instrument at the margin of the cornea towards the external canthus and at the margin of the former, just where you will enter the tip, and there make an impression (mark or puncture)—a small pit. This slight cut will, first, try out the patient's endurance and gain his confidence; second, it will create a place for the point of the needle where it will have a firm hold, will not slip off the eyeball nor fail to enter or to be easily removed during the operation...Direct the sharp, triangular end of the needle at the spot already marked out, pierce the conjunctiva and steadily push the needle towards the opposite and corresponding part of the eye until you feel that you have reached a roomy space within the eye" (126).

Likewise, the $11^{\text {th }}$ century oculist Ammar of Mosul, who practiced in Cairo, described:

"Then take a small knife, hold it in your right hand and open the conjunctiva at the lateral canthus at the same spot as is used for paracentesis. This spot should be two thirds of a barley-corn from the black part (limbus). Once you have opened the spot with the small knife, then slowly insert the needle in its place." (79).

Khalifah of $13^{\text {th }}$ century Aleppo explained the rationale:

"Mark the spot where you plan to penetrate by pressing the end of the handle of the cataract needle on it until you can see a depression. This is done for two reasons: first, to test the patient and to teach him patience; and second, to create a point for the tip of the needle from where it will not slip during entry." (79).

Khalifah also explained that if the needle did not penetrate the conjunctiva, then either a divider with a round tip (also called a barleycorn knife), or a regular lancet could be used to penetrate the conjunctiva first (Figure 15) $(54,79)$.

Following the medieval spread of Islam into India, we do find in the modern period that Indian oculists also use a two-instrument technique: a lancet followed by a needle (Figures 8,21) (54). Some of the needles resemble a narrow probe (Figure 8), but other couching "needles" feature a wider blade (Figure 21) $(54,142)$.

The indigenous couchers of Bhutan in 1775 obtained their instruments from Calcutta and also used first a lancet and then a copper probe (166).

According to the 1894 account by Shah of couching by a Muslim practitioner in East India, first a lancet was used which was "wrapped up in thread and a small portion of the point is left free" (164). Then, "A probe of copper, about 4 inches long, 3 inches of which is covered with thread is then used to depress the lens; one end of which is half an inch in length is free, and it is triangular or rather three-edged in shape." (164).

The 1826 account of English surgeon Peter Breton describing a Muslim oculist of Calcutta is one of the most detailed accounts of Eastern practices by a knowledgable eyewitness just prior to the development of modern medicine. The method is consistent with that of the medieval Arabic couchers, and did involve initial incision with a lancet (Figures 12,14,22) (2). Also note that while the probe was still in the eye, cotton was placed near the eye, and the eye was fomented, in the manner of Antyllus and Ibn Isa thousands of years before.

"...directing him [the patient] to look toward his nose, he [the doctor] in an instant with the right hand perforated the eye with a lancet. The perforation was made in the 
sclerotic coat, about a tenth of an inch from the margin of the cornea, and a little below the axis of the pupil; the lancet was allowed to penetrate to where the thread was wound, and was then withdrawn. The perforation thus made was sufficiently large to admit the introduction of the Indian couching needle (called by Sautcouree [the doctor], Sulaee, which in Hindee means a coarse needle,) and through the perforation the needle was gently introduced as far as its neck, into the vitreous humor, and afterwards allowed to remain pendulous from the eye for about half a minute, the needle being supported on a dossil of lint or cotton placed on the cheek to prevent it moving about, the collapse of the sclerotic coat on the neck of the needle preventing it from falling out of the eye; and so long as the instrument was kept free from motion, no irritation was excited. At this stage of the operation, the eyelids were allowed to close and the patient kept still as possible. After the lapse of half a minute, the eyelids were reopened with the fingers of the left hand, and the point of the needle was directed to the upper and outer part of the crystalline lens, the instrument being held nearly parallel with the axis of the pupil, and the lens and its capsule were together gently pressed downwards into the vitreous humor, and retained there a few seconds. The apex of the needle was then gently raised from the lens, and on the latter rising with the instrument, it was again and again depressed till it entirely disappeared. After this the eyelids were again closed, the needle let go, and allowed to hang as before for a few seconds from the tunics of the eye, supported on a bit of cotton placed on the cheek, and the patient kept quite still. During this interval an ignited gool (ball made of charcoal and clay), previously prepared, was placed in a shallow earthen cup, and held near the eye to foment it, with a view to relieve spasmodic affection of the eye that might be present. The eyelids were afterwards again opened, and the patient was directed to draw in his breath several times forcibly through his nose, and at the same time Sautcouree with his clasped hand gave him two or three gentle pats on the head, with the view, I was told, to cause the lens to be forced downwards, and drawn into the interior part of the eye out of the sphere of vision; and if no opacity were perceptible behind the pupil, the patient was asked if he could discover objects, if he could tell how many fingers were held before him, and if he could see a thread drawn out before his eye. On the patient answering in the affirmative, the operation was pronounced finished, the needle was withdrawn, a piece of combed cotton placed on the eyelids..." (2).

After careful study, Breton was so impressed with the local technique that he subsequently taught it to native medical students. Therefore, on the eve of the discovery of antisepsis and anesthesia, an informed doctor viewed the Indian cataract surgical technique as the preferred method.

It appears that in sub-Saharan Africa, a needle or thorn technique is used, rather than the two-instrument lancetneedle technique (52). However, the needle in Sudan was described as a "narrow knife" and therefore may resemble the medieval Arabic triangular needle (94).

Interestingly, the Essential Subtleties on the Silver Sea of the $14^{\text {th }}$ century described marking the puncture site with a "bronze hairpin", and then entering the eye with "a pointed needle", followed by entering the eye with the "earth" needle, and then the "heaven" needle, which is used to "remove the shade" (93). The earth and heaven needles might be different ends of the same instrument (93). As noted above, the medieval techniques may have diffused eastward.

\section{Furniture}

It is not until the $12^{\text {th }}$ or $13^{\text {th }}$ century writings of Benevenutus Grassus that the patient is lifted off the ground to be at the same level as the doctor (148). Here the patient and doctor face each other, straddling the same bench as if riding a horse.

Interestingly, in the Chinese work Essential Subtleties on the Silver Sea (Yinhai jingwei) written between 1343 and $1373 \mathrm{AD}$, the same pose is adopted:

"One sits down together with the patient, astride on the padded bench, facing one another and keeping [the eyes] at the same level." (93).

Grassus used a gold or silver needle, while the Silver Sea text recommended a golden needle $(87,93)$. The similarities between these texts despite wide geographic separation suggests that the eastern and western methods did not develop in complete isolation, but could both be influenced by the same technological and cultural forces.

Having the patient sit in a chair became the standard in the European Middle Ages. Gilles le Muisit (1272-1353), a Benedictine abbot in Tournai, had his cataracts successfully couched by an itinerant oculist from Mainz in 1351. Le Muisit was pictured in the medieval manuscript recording the event sitting in a chair which had no arms, with an assistant behind while the doctor stood (Figure 23, Annales, Bruxelles 13076-77, book IV, fol. 50V) (167).

\section{Medieval and modern spread of couching}

The spread of cataract couching in the medieval and 


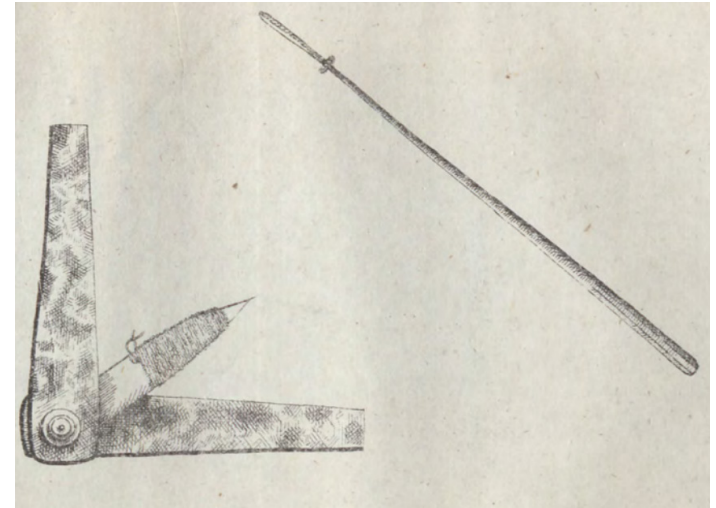

Figure 22 A lancet and needle wrapped in cotton, observed by British surgeon Peter Breton in Calcutta in 1826.

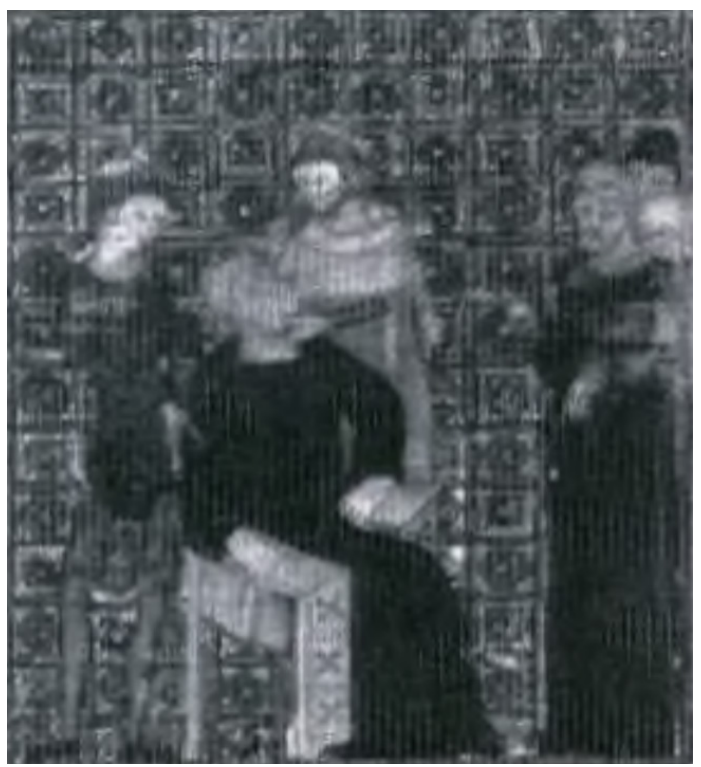

Figure 23 Abbot Gilles le Muisit of Tournai seated while having his cataract couched in 1351 .

modern periods might provide clues about where couching originated.

The knowledge of cataract couching spread into many East Asian regions. Couching was described in detail in China, Japan, Korea, Tibet (91), Nepal (22-25,168), Bhutan $(91,166)$, and Burma (169). We did not find evidence of traditional couching in far southeast Asia: Cambodia, Thailand, Viet Nam, Indonesia, or the Philippines.

In many regions, couching served as a metaphor for spiritual enlightenment. A symbolic Buddhist ritual involving a cataract operation with a śalākā was described in Sanskrit with commentary in Old Javanese (17). The symbolic rite in Tantrism of touching the initiate, often on the eyes, with a golden wand was present in Tibet and in Japan, according to the Vairocanasūtra (T 848:2:12a), the Mahāparinirvāna-sūtra (T 374:8:411c), and the Tattvasamgraba (T 866:4:252a) (17). Examples of these symbolic wands were imported into Japan from China in the $9^{\text {th }}$ century (17). Of course, such metaphors in a particular region do not prove the existence of the actual practice of couching.

Couching is also described in Africa. In 1653, a patient travelled from Dienné to Timbuktu where he was successfully operated for cataract (170). Cataract surgery was also performed in Darfur in the nineteenth century (171). In the modern period, cataract couching by traditional healers is found primarily in the regions of North Africa, spreading downward into the same areas where Islam had spread: Nigeria, Sudan, etc. (94). In 1938, Max Meyerhof of Egypt wrote that the traditional healers in his area were Moors, or came from Algeria, with just a few local Egyptians (150). The fact that couching has not traditionally been practiced in the more Southern areas of Africa, such as the Congo, could suggest that couching arrived in conjunction with Islam, and, in any event, probably did not start well South of the Sahara. For instance, if couching had started in the areas of modern-day Nigeria, then it probably would have moved Southward with the waves of Bantu migration in the Common Era.

In the New World, cataract couching was found in Mexico as early as 1611 (14). The procedure was not found in the English-speaking areas of the Caribbean until 1751, and along the east coast of North America until $1761(4,13)$.

One anomaly could call into question the single-origin theory of cataract couching. In a paper on cataract surgery in Papua New Guinea, we read that one 52-year-old woman had bilateral couching performed by a "traditionalist" (172). Upon inquiry with the authors, we learn that cataract couching in the country is not known on the main island of Papua, but occurs by traditional healers in Bougainville, in the Solomon Islands (Personal communication, Garry Brian, 2019). This is believed to be a traditional healing technique, rather than a skill taught to the islanders by Westerners. Bougainville is $6,500 \mathrm{~km}$ (4,000 miles) from Myanmar along the peninsulas and archipelagos of Thailand, Malaysia, Indonesia, and Papua, in which we could not find evidence of couching. Whether couching arrived by a wayward traveler, or whether it originated de 


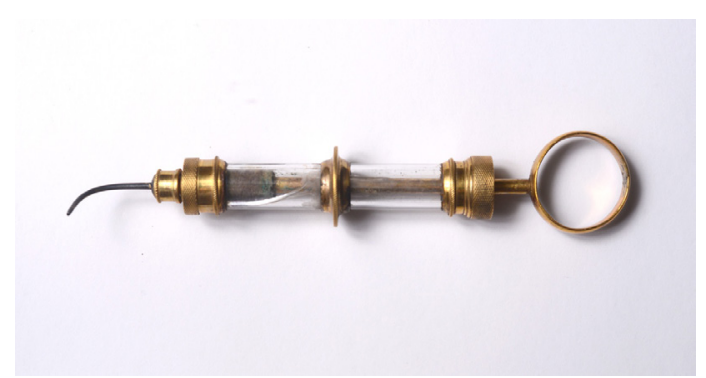

Figure 24 Syringe from the ophthalmic instrument set of Philip Syng Physick of Philadelphia, who was known to have extracted cataracts by aspiration by 1815 .

novo in Bougainville is unknown.

\section{Modern cataract extraction}

In $18^{\text {th }}$ century France came the realization among mainstream surgeons that the lesion treated by couching of cataracts was actually an opaque crystalline lens, following the work of Antoine Maitre-Jan, submitted for publication in 1704, and Michel Brisseau, presented in 1705. From time-to-time, lenses which were being couched would accidentally sublux into the anterior chamber, and in the early 1700s, numerous surgeons, such as Charles de Saint Yves, John Thomas Woolhouse, and John Taylor would extract such subluxed lenes with an inferior corneal incision $(173,174)$.

The design for tools to aspirate blood, aqueous, and "other floating particles" in the anterior chamber after couching were published by Archibald Cleland of Bath, England, in 1741 (175). Cleland also created forceps "to engage it [the cataract], and carefully bring it out of the eye." (175). It is not actually clear that Cleland actually performed cataract surgery, or even constructed the tools.

The era of planned cataract extraction came in the mid1700s (174). An extremely technically proficient surgeon could pull off cataract extraction with the tools available at that time, but many surgeons continued to prefer couching. Surgeons did not initially use pharmacologic dilation with belladonna, did not have anesthesia, did not understand the need for asepsis, and did not have operating microscopes. For all these reasons, a corneoscleral suture was not feasible. It is astonishing that anyone could successfully perform cataract extraction in the 1700s, given all of these limitations. And yet, there were some successful, highvolume itinerant cataract extractors in Europe, such as
Baron Wenzel, Jean-Francois Pellier, and Frederick William Jericho, the latter of whom is the earliest identified oculist to introduce cataract extraction to the New World by 1776 $(4,13)$.

Pharmacologic dilation with belladonna before cataract extraction was beginning to be used in Europe in the early 1800 s, and the corresponding use of the locally-available stramonium was suggested by a doctor in Kentucky in 1801 (4).

Cataract surgery by aspiration was reintroduced in the west in 1815 by Philip Syng Physick of Philadelphia. He successfully aspirated the cataract of an attorney named Francis B. Shaw, who was able to return to the practice of law for at least 14 years (176). Physick had performed the surgery on one other patient by early 1816 . His cataract set included a syringe that attaches to either a straight or curved cannula (Figure 24) (176). Physick's advance was not copied by other surgeons immediately. In France, Stanislas Laugier began aspirating cataracts in 1847 (176).

General anesthesia became common in many specialties in the 1840s. Ether anesthesia was publicly demonstrated in 1846 in Boston. Chloroform anesthesia was used in 1847 in Scotland. Some eye surgeons used general anesthesia, but opinion was polarized because of the risks. General anesthesia did, of course, require the patients to be supine. For ophthalmic surgeries, the real revolution came with the 1884 presentation of the discovery by Karl Koller of Vienna that topical cocaine could anesthetize the eye. Topical cocaine ophthalmic anesthesia was rapidly adopted throughout the world.

Surgical antisepsis with carbolic acid was described by Joseph Lister in 1867. Initial efforts to sterilize in ophthalmology as recommended by Lister with carbolic acid in the form of a spray, solution, or gas were problematic because the carbolic acid could damage the eye (177). In the 1880s, although spraying the eye with carbolic acid was abandoned, some surgeons did soak their instruments in this acid (178). Ultimately, substitutes were found for ophthalmology: 4 per cent boric acid, mercuric salt solutions, or heated distilled water with sodium chloride added (177).

Intracapsular cataract extraction was also performed by Samuel Sharp, and by others, beginning in the 1750 s. One advantage of the intracapsular technique was that it eliminated secondary vision loss from posterior capsular opacification. This procedure lagged in popularity, however due to the risks of vitreous loss and infection. Intracapsular 
extraction became more popular with the 1900 report of Col. Henry Smith in India at the turn of the $20^{\text {th }}$ century to extract the lens in toto using a strabismus hook, and other techniques to remove the lens by traction, such as with a suction cup in 1902, diathermo-coagulation with a needle in 1932, and a syringe in 1933 (179). In 1957, Joaquin Barraquer demonstrated that the enzyme $\alpha$-chymotrypsin could dissolve the zonules of the lens, which facilitated its removal (179). Cryoextraction rapidly became a mainstream technique for two decades after its introduction by Tadeusz Krwawicz (1910-1988) of Poland in 1961 (180).

Head-mounted loupes, such as the Berger loupe of 1900, were used by many ophthalmologists. The Czapski corneal microscope, manufactured by the Zeiss corporation beginning in 1897 , was used to examine the eye. However, surgical use of microscopes by ophthalmologists was initially limited to corneal foreign body removal. When ophthalmologist Richard Troutman recommended the operating microscope in cataract surgery in 1965, its use was not widespread, except for aspiration of congenital or particularly soft cataracts (181). However, just two years later in 1967 when Charles Kelman presented his initial report on phacoemulsification, he wrote: "The use of an operating microscope is mandatory." (182).

Harold Ridley performed the first implantable intraocular lenses in 1949 (179). However, acceptance of the lenses was slow. In the 12 months after August 1978, just 154,000 intraocular lenses were implanted in the United States, and most of these were iris fixated (183). But uptake after this point was rapid. In the 12 months after August 1981, 409,000 lenses were implanted, primarily posterior chamber and anterior chamber intraocular lenses (183). By 1983, 17 lenses from 7 manufacturers were FDA-approved in the United States (183). With posterior chamber lenses, it was important to leave the posterior capsule intact in order to hold the lens. Moreover, with the advent of YAGlaser posterior capsulotomy in 1980 (179), secondary opacification of the posterior capsule would not require a second trip to the operating room. Thus, in the era of phacoemulsification and posterior chamber intraocular lens implantation, extracapsular cataract surgery became the standard of care.

\section{Conclusions}

Similarities between ancient eastern and western descriptions of cataract couching suggest that the procedure originated once, and then spread throughout the world.
Early Greek and Sanskrit descriptions of cataract couching both involve: the requirement for maturity of the cataract, comparison of some eyes to glass, a preference for patients of intermediate ages, rubbing the eye, having a wide portion of the couching instrument shaft, pars-plana puncture with avoidance of the blood vessels, and immediate vision testing $(184,185)$. In ancient Greece and India, the words for a healthy blue eye (glaukos and nilla, respectively) were also used to characterize an eye with poor vision which could not be cured by surgery. In both Greek and Indian works, the crystalline lens was compared to a lentil, and colored entoptic phenomena were described. The time and place that cataract surgery originated cannot be stated with certainty. The primary candidates are Egypt and India.

The ancient Greek author pseudo-Galen suggested an Egyptian origin. There was enough time for cataract surgery to develop along the Nile, to be (possibly) sought by Cyrus of Persia in the $6^{\text {th }}$ century BCE, to be discovered by the Greeks with the founding of Alexandria in $331 \mathrm{BCE}$, to be mentioned by Chrysippus of Soli in the $3^{\text {rd }}$ century BCE, to be carried to Taxila by the Persians before Alexander the Great (or by the ambidextrous Greeks afterwards), and then to be described in the Suśrutasambitā in India in the early Common Era. A Mediterranean origin is suggested by the emphasis on ambidexterity. The apparently Indian features in the cataract descriptions of Antyllus could have resulted from later back-transfer of Indian ideas towards the West.

On the other hand, an Indian origin for the original solid needle couching procedure described by Celsus and by Susruta was suggested by the medieval Persian Zarrin-Dast, as well as by Indian tradition. The well-developed discussion of the pathophysiology and treatment of cataract, as well as the tight integration of the tridosa (humoral) theory in the Indian works with the understanding of cataract suggests a long and established tradition. An Indian origin is suggested by the Indo-Greek practices of having the patient sit, ocular convergence towards the nose, and possibly putting cotton on and blowing on the eye. There was enough time for unwritten ophthalmic practices to be carried from India to Egypt before the time of Alexander the Great, followed by discovery of the procedure by the Greeks upon the creation of his empire.

In the area from the Mediterranean to Mesopotamia, we see a great deal of ophthalmic innovation. In addition to cataract couching with a solid needle, soft cataracts were intentionally divided in Greco-Roman practice (Table 3). Moreover, the ancient Greco-Romans, and their medieval Arabic successors, described cataract aspiration by suction 
Table 3 Levels of evidence for type of cataract surgery by time period

\begin{tabular}{|c|c|c|c|c|c|}
\hline Period & Couching. & Discission/division & Aspiration & Extraction-Limbal Incision & $\begin{array}{l}\text { Expulsion around } \\
\text { embedded needle }\end{array}$ \\
\hline Antiquity & Described & Described & Described & Possible & Hypothesized \\
\hline Middle Ages & Detailed accounts & Detailed accounts & Detailed accounts & Possible & No \\
\hline 1700 s or 1800 s & Detailed accounts & Detailed accounts & Detailed accounts & Detailed accounts & No \\
\hline
\end{tabular}

through a tube. Removal of a cataract by an inferior corneal incision is briefly alluded to in Greco-Roman antiquity and in the medieval period, but the descriptions are not detailed enough to exclude the possibility that a hypopyon was being drained.

Finally, a number of Indo-Arabic authors described the cataract patient inhaling vigorously while the couching needle was embedded in a pars plana puncture. We have discussed a variety of hypotheses which might account for this practice. The reader who wishes to find the relevant page numbers for each cited reference is invited to review http://fp.amegroups.cn/cms/466c3cefa54694e10cfbb91c0a0 c183d/atm-2019-rcs-04-1.docx.

\section{Acknowledgments}

Funding: None.

\section{Footnote}

Provenance and Peer Review: This article was commissioned by the Guest Editor (Dr. Andrzej Grzybowski) for the series "Recent developments in cataract surgery" published in Annals of Translational Medicine. The article was sent for external peer review organized by the Guest Editor and the editorial office.

Conflicts of Interest: All authors have completed the ICMJE uniform disclosure form (available at http://dx.doi. org/10.21037/atm-2019-rcs-04). The series "Recent developments in cataract surgery" was commissioned by the editorial office without any funding or sponsorship. AG served as the unpaid Guest Editor of the series. The authors have no other conflicts of interest to declare.

Ethical Statement: The authors are accountable for all aspects of the work in ensuring that questions related to the accuracy or integrity of any part of the work are appropriately investigated and resolved.
Open Access Statement: This is an Open Access article distributed in accordance with the Creative Commons Attribution-NonCommercial-NoDerivs 4.0 International License (CC BY-NC-ND 4.0), which permits the noncommercial replication and distribution of the article with the strict proviso that no changes or edits are made and the original work is properly cited (including links to both the formal publication through the relevant DOI and the license). See: https://creativecommons.org/licenses/by-nc-nd/4.0/.

\section{References}

1. Meulenbeld GJ. A History of Indian Medical Literature. Vol. IA. Text. Groningen: Forsten, 1999:303-651.

2. Breton P. On the native mode of couching. Transactions of the Medical and Physical Society of Calcutta. 1826:341-82.

3. Mishima S. The history of ophthalmology in Japan. Oostende: Wayenborgh, 2004.

4. Leffler CT, Schwartz SG, Wainsztein RD, et al. Ophthalmology in North America: Early Stories (14911801). Ophthalmol Eye Dis 2017;9:1179172117721902.

5. Leffler CT, Schwartz SG, Hadi TM, et al. The early history of glaucoma: the glaucous eye (800 BC to 1050 AD). Clin Ophthalmol 2015;9:207-15.

6. Hirschberg J, Blodi FC (trans.). The History of Ophthalmology. Vol. 1. Antiquity. Bonn: Wayenborgh Verlag, 1982:34-349.

7. Jamison SW, Brereton JP. The Rigveda: The Earliest Religious Poetry of India. Oxford: Oxford University Press, 2014:3-276.

8. Rajagopal M. Salakyatantra. Diseases of supra-clavicular parts. In: Subbarayappa BV. editor. History of Science, Philosophy and Culture in Indian Civilization. Vol. IV, Part 2. Medicine and Life Sciences in India. New Delhi: Munshiram Manoharlal Publishers, 2001:192-291.

9. Ascaso FJ, Lizana J, Cristóbal JA. Cataract surgery in ancient Egypt. J Cataract Refract Surg 2009;35:607-8.

10. Blomstedt P. Cataract surgery in ancient Egypt. J Cataract 
Refract Surg 2014;40:485-9.

11. Grzybowski A, Ascaso FJ. Indirect evidence of cataract surgery in ancient Egypt. J Cataract Refract Surg 2014;40:1944-5.

12. Geller MJ. Ancient Babylonian Medicine: Theory and Practice. Oxford: Wiley-Blackwell, 2010:58-184.

13. Leffler CT, Schwartz SG, Grzybowski A, et al. The first cataract surgeons in Anglo-America. Surv Ophthalmol 2015;60:86-92.

14. Leffler CT, Wainsztein RD. The first cataract surgeons in Latin America:1611-1830. Clin Ophthalmol 2016;10:679-94.

15. Salguero CP. The Buddhist medicine king in literary context: reconsidering an early medieval example of Indian influence on Chinese medicine and surgery. History Religions 2009;48:183-210.

16. Zysk KG. Asceticism and Healing in Ancient India: Medicine in the Buddhist Monastery. New York: Oxford University Press, 1991:46.

17. Demiéville P, Tatz M (trans.). Buddhism and Healing. Demiéville’s Article "Byō" from Hōbōgirin. New York: University Press of America, 1985:20-91.

18. Naqvi NH. Surgical instruments in the Taxila Museum. Med Hist 2003;47:89-98.

19. Mishra SK. Ayurveda, Unani and Siddha systems: An overview and their present status. In: Subbarayappa BV. editors. History of Science, Philosophy and Culture in Indian Civilization. Vol. IV, Part 2. Medicine and Life Sciences in India. New Delhi: Munshiram Manoharlal Publishers, 2001:481.

20. Suśruta, Trikamjī Ācārya VJ, Ācārya 'Kāryatīrtha' NR. editor. Suśruta Saṃhitā of Suśruta with the Nibandhasanggraha Commentary of Śrī Dalhaṇācārya and Nyāyacandrika Pañjikā of Śrī Gayadāsācārya on Nidānasthāna. Varanasi: Chaukhamba Krishnadas Academy, 2004:1-100.

21. Wujastyk D. The Roots of Āyurveda. New Delhi: Penguin 1998:105.

22. Klebanov A. The Nepalese version of the Suśrutasampitā and its Interrelation with Buddhism and the Buddhists. M.A. thesis submitted to the Hamburg University on September 6, 2010. Accessed January 12, 2019. Available online: https://www.academia.edu/12177425/The Nepalese_version_of_the_Su\%C5\%9Brutasa\%E1\%B9\% 83hit\%C4\%81_and_its_Interrelation_with_Buddhism_ and_the_Buddhists

23. Wujastyk D. New manuscript evidence for the textual and cultural history of early classical Indian medicine. In:
Wujastyk D, Cerulli A, Preisendanz K. editors. Medical Texts and Manuscripts in Indian Cultural History. New Delhi: Manohar, 2013:141-57.

24. Harimoto K. In search of the oldest Nepalese manuscript. Rivista degli studi orientali 2011;84:85-106.

25. Harimoto K. Nepalese Manuscripts of the Suśrutasaṃitā. Journal of Indian and Buddhist Studies 2014;62:23-9.

26. Klebanov A. On the textual history of the Suśrutasamhitā: A study of three Nepalese manuscripts. Accessed October 22, 2020. Available online: http://sushrutaproject. org/2020/10/03/new-article-by-andrey-klebanov-in-press/

27. Meyerhof M. 'Alî at-Tabarî's "Paradise of Wisdom", one of the oldest Arabic Compendiums of Medicine. Isis 1931;16:6-54.

28. Kahl O. The Sanskrit, Syriac and Persian sources in the Comprehensive book of Rhazes. Leiden: Brill, 2015:44-46.

29. Meulenbeld GJ. A History of Indian Medical Literature. Volume IIA. Text. Groningen: Forsten, 2000:72.

30. Von Staden H. Herophilus - the art of medicine in early Alexandria. Cambridge: Cambridge University Press, 1989:20-578.

31. Beckwith CI. Greek Buddha. Pyrrho's Encounter with Early Buddhism in Central Asia. Princeton: Princeton University Press, 2015:8-113.

32. McEvilley T. The Shape of Ancient Thought. Comparative Studies in Greek and Indian Philosophy. New York: Allworth Press, 2002:1-450.

33. Simplicius of Cilicia. Kalbfleisch C. editor. Commentaria in Aristotelem Graeca. Vol. VIII. Simplicii in Aristotelis Categorias Commentarium. Berlin: Reimeri, 1907:401. Accessed January 4, 2020. Available online: https://archive. org/stream/inaristoteliscat08simp\#page/400/mode/2up

34. Simplicius of Cilicia. Gaskin R (trans.) Simplicius: on Aristotle categories 9-15. London: Bloomsbury Academic, 2013:143.

35. Theophrastus. Hort AF (trans.). Enquiry into Plants. Vol. I. Books 1-5. Loeb Classical Library 70. Cambridge, MA: Harvard University Press, 1916:470-1.

36. Diogenes Laertius. Hicks RD (trans.). Lives of Eminent Philosophers, Volume I. Books 1-5. Loeb Classical Library 184. Cambridge: Harvard University Press, 1925:440-3.

37. Maximus of Tyre. Trapp MB (trans.) The Philosophical Orations. Translated by M. B. Trapp. Oxford: Clarendon Press, 1997:87.

38. Theophilus of Antioch. Grant RM (trans.). Theophilus of Antioch ad Autolycum. Oxford: Clarendon Press, 1970:4-11.

39. Calcidius. Magee J (trans.). On Plato's Timaeus. 
Cambridge, MA. Harvard University Press, 2016:504.

40. Leffler CT, Schwartz SG. Glaucoma in the ancient Greek and Roman worlds. In: Leffler CT (ed.) The History of Glaucoma. Oostende: Kugler/Wayenborgh, 2020:1-46.

41. Jouanna J. Allies N (trans.). Egyptian Medicine and Greek Medicine. In: Greek Medicine from Hippocrates to Galen: Selected Papers. Leiden: Brill, 2012:15-6.

42. Galien, Kühn KG (éd.). Introductio Seu Medicus. Galeni opera omnia. vol. 14. Leipzig: Car. Cnoblochii, 1827:675. Accessed February 23, 2020. Available online: https://www. biusante.parisdescartes.fr/histoire/medica/resultats/index. php? do $=$ page $\&$ cote $=45674 \times 14 \&$ p $=677$

43. Friedenwald J, Morrison S. The history of the enema with some notes on related procedures (Part I). Bull Hist Med 1940;8:68-114.

44. Berrey M. Chrysippus of Cnidus: medical doxography and Hellenistic monarchies. Greek Roman Byz Stud 2014;54:420-43

45. Aëtius of Amida, Waugh RL (trans.). The Ophthalmology of Aëtius of Amida. Oostende: Wayenborgh, 2000:85-6.

46. Marganne $\mathrm{MH}$. Inventaire analytique des papyrus grecs de médecine. Genève: Droz, 1981:7-267.

47. Marganne MH. L'ophtalmologie dans l'Egypte grécoromaine d'après les papyrus littéraires grecs. New York: E.J. Brill, 1994:120-1.

48. Narayana A, Thrigulla SR. Tangible evidences of surgical practice in ancient India. Journal Ind Med Heritage 2011;XLI:1-18.

49. Elliot R. The Indian Operation of Couching for Cataract. New York: Hoeber, 1918:14.

50. Heuzé V, Tran G, Eugène $M$, et al. Babul (Acacia nilotica) 2016. Accessed January 18, 2020. Available online: https:// agritrop.cirad.fr/582523/1/ID582523.pdf

51. Ebeigbe JA. Traditional eye medicine practice in BeninCity, Nigeria. South African Optometrist 2013;72:167-72.

52. Al Safi A. Traditional Sudanese Medicine: a Primer for Health Care Providers, Researchers, and Students. Khartoum: al Safi, 2006:156-395.

53. Beiram MMO. Traditional and folk medicines in ophthalmology. Sudan Medical Journal 1971;9:161-6.

54. Hirschberg J, Blodi FC (trans.). The History of Ophthalmology. Volume Two. The Middle Ages; the Sixteenth and Seventeenth Centuries. Bonn: Wayenborgh Verlag, 1985:41-685.

55. Leffler CT, Schwartz SG, Peterson E, et al. Cataract couching and the goat's eye. Acta Ophthalmol 2018;96:755-6.

56. Paulus Aegineta. Adams F (trans.). The Seven Books of
Paulus Aegineta: Translated from the Greek. Volume 2. London: Sydenham Society. 1846:279-80.

57. Künzl E. Medizinische Instrumente aus Sepulkralfunden der Römischen Kaiserzeit. Cologne: Rheinland Verlag GmbH, 1983:12-114.

58. Jackson R. A set of Roman medical instruments from Italy. Britannia 1986;17:267-71.

59. Hibbs VA. Roman surgical and medical instruments from La Cañada Honda (Gandul). Archivo Español de Arqueología 2018;64:111-34.

60. Edge C, Gibbins D. Underwater discovery of Roman surgical equipment. BMJ 1988;297:1645-6.

61. Gibbins DJ. The Roman wreck of c. AD 200 at Plemmirio, near Siracusa (Sicily): second interim report: The domestic assemblage 1: medical equipment and pottery lamps. Int J Naut Archaeol 1989;18:1-25.

62. Milne JS. Surgical Instruments in Greek and Roman Times. Oxford: Clarendon Press, 1907:69-176.

63. Hassel FJ, Künzl E. Ein römisches Arztgrab des 3. Jahrhunderts n. Chr. aus Kleinasien. Medizinhist J 1980;15:403-21.

64. Tontchéva G. Découvertes de tombes d'Odessos. Bulletin de la Société Archéologique à Varna 1961;12:39-40.

65. Meyer-Steineg T. Die Starnadel aus Kos. Chirurgische Instrumente des Altertums. Jena: Fischer, 1912:45.

66. Baker P. Collyrium Stamps: An Indicator of Regional Practices in Roman Gaul. Eur J Archaeol 2011;14:158-89.

67. Feugère M, Künzl E, Weisser U. Les aiguilles à cataract de Montbellet (Saône-et-Loire). Contribution à l'étude de l'ophtalmologie antique et Islamique. Die starnadeln von Montbellet (Saône-et-Loire). Ein beitrag zur antiken und Islamischen augenheilkunde. Jarbuch des RömischGermanischen Zentralmuseums Mainz 1985;32:24-508.

68. Heymans H. Eine Hülse mit Arztinstrumenten aus Maaseik (Belgien). Archäologisches Korrespondenzblatt 1979;9:97-100.

69. Heymans H, Janssens P. De 'Trousse d'Oculiste' van Maaseik. Hades 1975-76;14-15:10-12.

70. Reggiani Massarini AM. Indagini sui materiali dell'Antiquario del Museo Nazionale Romano. Archaeologia Laziale 1988;9:455-66.

71. Baker P. Roman medical instruments: archaeological interpretations of their possible 'non-functional' uses. Soc Hist Med 2004;17:3-21.

72. Bliquez LJ. Two lists of Greek surgical instruments and the state of surgery in Byzantine times. Dumbarton Oaks Papers, Vol. 38, Symposium on Byzantine Medicine, 1984:187-204. 
73. Holth S. "Greco-Roman and Arabic bronze instruments and their medico-surgical use" Videnskapsselskapets Skrifter. I. I. Maternatisk-Naturvidenskabelig. No. 1. Klasse, Kristiana, 1919:3-20.

74. Holth S. An Arabic bronze needle from antiquity for depression of cataract. Br J Ophthalmol 1924;8:266-8.

75. Jackson R. Medicine and hygiene. In: Allason-Jones L. Artefacts in Roman Britain: Their Purpose and Use. New York: Cambridge University Press, 2011:243-68.

76. Jackson R. Toilet implement. Accessed May 20, 2018. Available online: https://finds.org.uk/database/artefacts/ record/id/152324

77. Jackson R. Roman doctors and their instruments: recent research into ancient practice. J Roman Archaeol 1990;3:5-27.

78. Baker PA. Medical Care for the Roman Army on the Rhine, Danube and British Frontiers in the First, Second and Early Third Centuries AD. Thesis University of Newcastle upon Tyne, 2000.

79. Blodi FC, Rademaker WJ, Rademaker G, et al. The Arabian Ophthalmologists. Compiled from original texts by J. Hirschberg, J. Lippert and E. Mittwoch. Riyadh: King Abdulaziz City for Science and Technology, 1993:152-302.

80. Suśruta, Sharma PV. Suśruta-saṃhitā. With English translation of text and Dalhana's commentary along with critical notes. Vol. III. (Kalpasthana and Uttaratantra). Varanasi: Chaukhambha Visvabharati, 2014:141-619.

81. Suśruta. Suśrutasaṃhitā Bhāṣāṭ̂ikayā saṃbhūṣitā. Vol. 1. Mumbai: Śrīveñkateśvar Steam Press, 1911:14. Accessed January 19, 2020. Available online: https://archive.org/ details/SushrutaSamhita_201709/page/n14

82. Jackson R. An ancient British medical kit from Stanway, Essex. Lancet 1997;350:1471-3.

83. Deshpande V. Ophthalmic surgery: a chapter in the history of Sino-Indian medical contacts. Bull Sch Orient Afr Stud 2000;63:370-88.

84. Ekamabram R. Couchers and Their Methods. Ind Med Gaz 1910;45:110-3.

85. Abū Bakr Muḥammad ibn Zakarīyā Rāzī. Faraj ben Salim (trans.). Continens Rasis. Venice: Johannes Hamman. 1529:41. Accessed January 20, 2020. Available online: https://www.wdl.org/en/item/9553/view/1/102/

86. Meyerhof M. L'operation de la cataracte du Chirurgien Antylle d'Alexandrie. In: Koumaris J (ed.). Livre d'or à l'occasion du jubilé de vingt-cinq ans d'activité chirurgicale du docteur Théodore L. Papayoannou ... Le Caire, le 8 mai 1932. Naumburg-Saale: Lippert \& Co, 1932:115-9.
87. Grapheus B. Wood CA (trans.). De Oculis Eorumque Egritudinibus Et Curis. Stanford: Stanford University Press, 1929:33-148.

88. Yonten Arya P. External therapies in Tibetan medicine: the Four Tantras, contemporary practice, and a preliminary history of surgery. Hofer T (ed.) Bodies in Balance: The Art of Tibetan Medicine. Seattle: University of Washington Press, 2014:64-89.

89. Sangs-rgyas-rgya-mtsho (Sde-srid). Desi Sangye Gyatso. Mirror of Beryl: A Historical Introduction to Tibetan Medicine. Boston: Simon and Schuster, 2010:147-520.

90. Thomas FW. Tibetan Documents concerning Chinese Turkestan. I: the Ha-za. J R Asiat Soc GB Irel 1927;59:51-85.

91. Rambo VC. Couching operation in Tibet. AMA Arch Ophthalmol 1955;54:471-3.

92. Deshpande VJ. Buddhism as a vehicle for medical contacts between India and China. Annals of the Bhandarkar Oriental Research Institute 2008;89:41-58.

93. Kovacs J, Unschuld PU. Essential Subtleties on the Silver Sea. The Yin-hai jing-wei: a Chinese Classic on Ophthalmology. Berkeley. University of California Press, 1998:404-5.

94. Crichton-Harris A. Poison in small measure: Dr. Christopherson and the cure for bilharzia. Leiden: Brill, 2009:311.

95. Nene YL. Indian pulses through the millennia. Asian AgriHistory 2006;10:179-202.

96. Robinson ML, Lovicu FJ. The lens: historical and comparative perspectives. In: Robinson ML, Lovicu FJ (eds.). Development of the Ocular Lens. Cambridge University Press, 2004:5-273.

97. Longrigg J. Anatomy in Alexandria in the Third Century B.C. Br J Hist Sci 1988;21:455-88.

98. Shastid TH. History of ophthalmology. In: Wood CA, editor. The American Encyclopedia and Dictionary of Ophthalmology. Vol. XI. Chicago: Cleveland Press, 1913:8580-8.

99. Abu Ali al-Husayn ibn Abd Allah ibn Sina (Avicenna), Sardo PA (trans.). Bakhtiar L (ed.). The Canon of Medicine (al-Qanun fi'l-tibb) (The Law of Natural Healing). Volume 3. Special Pathologies. Chicago: Kazi Publications, 2014:207-74.

100.Sushruta, Bhishagratna KKL (trans.). An English Translation of the Sushruta Samhita. Vol. III. UttaraTantra. Calcutta: Bhaduri, 1916:25-79.

101. Sharma PV. Suśruta-saṃhitā. With English translation of text and Dalhana's commentary along with critical notes. 
Vol. I. (Sūtrasthanā). Varanasi: Chaukhambha Visvabharati, 2018:61-275.

102. Celsus, Spencer WG (trans.). On Medicine (De Medicina). Vol 3. London: William Heinemann Ltd, 1938:296-386.

103.Leffler CT, Schwartz SG, Davenport B. Congenital cataract surgery during the early enlightenment period and the Stepkins oculists. JAMA Ophthalmol 2014;132:883-4.

104. Celsus, Spencer WG (trans.). On Medicine. Books I-IV. Volume I. Loeb Classical Library 292. Cambridge, MA. Harvard University, 1935:154-5.

105. Hippocrates of Cos, Potter P (trans.). Hippocrates V, Affections. Diseases 1. Diseases 2. Loeb Classical Library 472. Cambridge, MA. Harvard University Press, 1988:170-291.

106. Galen, Johnston I, Horsley GHR (trans.). Method of Medicine, Volume II, Books 5-9 2011. Cambridge, MA: Harvard University Press, 2011:398-9.

107.Leffler CT, Schwartz SG, Giliberti FM, et al. What was Glaucoma Called Before the 20th Century? Ophthalmol Eye Dis 2015;7:21-33.

108.Leffler CT, Schwartz SG. Glaucoma during the Enlightenment and Early Modern Periods (1700-1849). In: Leffler CT (ed.) The History of Glaucoma. Oostende: Kugler/Wayenborgh 2020:145-96.

109. Deshpande V. Indian Influences on Early Chinese Ophthalmology: Glaucoma as a Case Study. Bull Sch Orient Afr Stud 1999;62:306-22.

110.Monier-Williams M. A Sanskrit-English Dictionary. Etymologically and Philologically Arranged. Oxford: Clarendon, 1872:512-3.

111.Monier-Williams M. A Sanskrit-English Dictionary: Etymologically and Philologically Arranged. Delhi: Motilal Banarsidass Publishers 2005:1315.

112.Digital Corpus of Sanskrit. Suśrutasaṃhitā. Su, Utt., 7. Accessed December 19, 2019. Available online: http:// www.sanskrit-linguistics.org/dcs/index.php? contents=texte $\&$ PhraseID $=11956$

113. Bartisch G, Blanchard DL (trans.) Ophthalmodouleia: That is the Service of the Eyes 1583. Ostend: Wayenborgh, 1996:50-2.

114. Praxagoras, Steckerl F (trans.). The Fragments of Praxagoras of Cos and His School. Leiden: Brill, 1958:73-5.

115. Scharfe $\mathrm{H}$. The doctrine of the three humors in traditional Indian medicine and the alleged antiquity of Tamil Siddha medicine. J Am Orient Soc 1999;119:609-29.

116. Meulenbeld GJ. The constraints of theory in the evolution of nosological classifications: a study on the position of blood in Indian medicine (Ayurveda). In: Meulenbeld GJ. editor. Medical Literature from India, Sri Lanka, and Tibet. Panels of the VIIth World Sanskrit Conference. Vol VIII. Leiden: Brill, 1991:91-106.

117.Vāgbhata, Srikantha Murthy KR (trans.). Aștāngasamgraha. Vol. III. Uttarasthāna. 2nd ed. Varanasi: Chaukhambha Orientalia, 2000:133-55.

118. Jouanna J, Allies $\mathrm{N}$ (trans.). At the roots of melancholy: is Greek medicine melancholic? In: Greek Medicine from Hippocrates to Galen: Selected Papers. Leiden: Brill, 2012:236.

119. Celsus, Spencer WG (trans.). De Medicina. Vol. II. Cambridge, MA: Harvard University Press, 1938:62-222.

120. Laine J. Some remarks on the Guṇagunibhedabhanga chapter in Udayana's Ātmatattvavieka. J Indian Philos 1993;21:261-94.

121.Lucretius Carus T, Leonard WE (trans.). On the Nature of Things. London: Dent, 1921:147.

122.Leverett FP. A New and Copious Lexicon of the Latin Language. Boston: Wilkins, 1837:95.

123. Sextus Empiricus, Bury RG (trans.). Sextus Empiricus. Volume I. Outlines of Pyrrhonism. Loeb Classical Library 273. Cambridge, MA. Harvard University Press, 1933:28-9.

124. Neale M. Madhyamaka and Pyrrhonism. Doctrinal, Linguistic and Historical Parallels and Interactions between Madhyamaka Buddhism \& Hellenic Pyrrhonism. Regent's Park College, University of Oxford. DPhil. August 2014. Accessed March 1, 2020. Available online: https://ora.ox.ac.uk/objects/uuid:347ed882-f7ac-4098908f-5bb391462a6c/download_file?file_format=pdf\&safe_ filename=THESIS01\&type_of_work=Thesis

125. Galen, Johnston I (trans.). Galen. On Diseases and Symptoms. Cambridge: Cambridge University Press, 2006:211-3.

126. al-Kahhal Ibn Isa (Jesu Hali), Wood CA (trans.) In: Memorandum Book of a Tenth-Century Oculist. Chicago: Northwestern University;1936, 165-87.

127. Digital Corpus of Sanskrit. Suśrutasaṃhitā. Su, Utt. 17, 64.1. Accessed January 9, 2020. Available online: http:// www.sanskrit-linguistics.org/dcs/index.php?contents=texte \&PhraseID $=12476$

128. Albucasis, Spink MS, Lewis GL (trans.). Albucasis on Surgery and Instruments: Abu al-Qasim Khalaf Ibn Abbas al-Zahrawi. Berkeley: University of California Press, 1973:252-6.

129. Homer, Murray AT, Wyatt WF (trans.). Iliad, Volume II. Books 13-24. Loeb Classical Library 171. Cambridge, MA: 
Harvard University Press, 1925:416-7.

130. Gerber DE (Editor/Translator). Greek Iambic Poetry: from the Seventh to the Fifth Centuries BC (Loeb Classical Library, \#259). Cambridge, MA: Harvard University Press, 1999:452-3.

131. Hippocrates, Jones WHS (trans.). Hippocrates Volume IV. Loeb Classical Library 150. Nature of Man. Regimen in Health. Humours. Aphorisms. Regimen 1-3. Dreams. Heracleitus: On the Universe. Cambridge, MA: Harvard University Press, 1931:202-3.

132. Plato, Jowett B (trans.). The Dialogues of Plato. Vol. 4. London: Macmillan, 1871:308.

133. Ausloos H. The Story of Ehud and Eglon in Judges 3:1230: A Literary Pearl as a Theological Stumbling Block. Old Testament Essays. Accessed February 26, 2020. Available online: https://dx.doi.org/10.17159/2312-3621/2017/ v30n2a3

134. Aristotle, Peck AL (trans.). Aristotle Volume IX. History of Animals, Volume I. Books 1-3. Loeb Classical Library 437. Cambridge, MA: Harvard University Press, 1965:76-7.

135. Remow G. Aristotle, Antigone and natural justice. Hist Polit Thought 2008;29:585-600.

136. Procopius, Dewing HB (trans.). History of the Wars, Volume II. Books 3-4 (Vandalic War). Loeb Classical Library 31. Cambridge, MA: Harvard University Press, 1916:316-9.

137. Dhyansky YY. The Indus Valley Origin of a Yoga Practice. Artibus Asiae 1987;48:89-108.

138. De Coster PL (trans.). The Bhagavad Gita in English: the Sacred Song. Belgium: Gita Satsang Ghent Centre, 2010:115.

139.Pi HT. A brief historical sketch of native ophthalmology in China. National Medical Journal of China 1929;15:604-18.

140. Deshpande VJ, Ka-wai F. Restoring the Dragon's Vision: Nagarjuna and Medieval Chinese Ophthalmology. Hong Kong: City University of Hong Kong, 2012:111-261.

141.Leffler CT, Hadi TM, Udupa A, et al. A medieval fallacy: the crystalline lens in the center of the eye. Clin Ophthalmol 2016;10:649-62.

142.Drake-Brockman HE. The Indian oculist and his equipment. Transactions of the Ophthalmological Society of the United Kingdom, 1895;XV:249-53.

143. Drake-Brockman HE. The Indian oculist, his equipment, and methods. Indian Medical Gazette, 1910;207-10.

144. Gyllenbok J. Encyclopaedia of Historical Metrology, Weights, and Measures. Volume 1. Cham: Birkhäuser,
2018:498-503.

145.Sykorova A, Sarka E, Bubnik Z, Schejbal M, Dostalek P. Size distribution of barley kernels. Czech J Food Sci 2009;27:249-58.

146. Grant RL. Antyllus and his medical works. Bull Hist Med 1960;34:154-74.

147. Grant RL. Antyllus, the elusive surgical genius of antiquity: an analysis of his writings. Surgery 1961;50:572-8.

148.Leffler CT, Schwartz SG, Davenport B, et al. Enduring influence of Elizabethan ophthalmic texts of the 1580s: Bailey, Grassus, and Guillemeau. Open Ophthalmol J 2014;8:12-8.

149. Galen, Johnston I, Horsley GHR (trans.). Method of Medicine, Volume III, Books 10-14. Loeb Classical Library 518. Cambridge, MA: Harvard University Press, 2011:498-537.

150. 'Ammār ibn 'Alī Mawșilī, Meyerhof M. Las Operaciones de catarata de 'Ammar ibn 'Ali al-Mawsili. Barcelona: Laboratories del Norte de Espana, 1937:52-3.

151.Pérez-Cambrodí RJ, Ascaso FJ, Diab F, et al. Hollow needle cataract aspiration in antiquity. Acta Ophthalmol 2015;93:782-4.

152.Leffler CT, Samara WA, Hadi TM, et al. Glaucoma in the Medieval Arabic World. In: Leffler CT (ed.) The History of Glaucoma. Oostende: Kugler/Wayenborgh, 2020:47-74.

153.Lascaratos J, Marketos S. The cataract operation in ancient Greece. Hist Sci Med 1982;17:317-22.

154. Verma RL. The growth of Greco-Arabian medicine in medieval India. Indian J Hist Sci 1970;5:347-63.

155.Hunain Ibn Is-Haq (Johannitus), Meyerhof M (trans.). The Book of the Ten Treatises on the Eye Ascribed to Hunain Ibn Is-Haq (809-877 A.D.). Cairo: Government Press, 1928:122.

156. Moulherat C, Tengberg M, Haquet JF, et al. First evidence of cotton at Neolithic Mehrgarh, Pakistan: analysis of mineralized fibres from a copper bead. J Archaeol Sci 2002;29:1393-401.

157.Sushruta, Bhishagratna KKL (trans.). An English Translation of the Sushruta Samhita. Vol. I. Sutrasthanam. Bose: Bhaduri, 1907:257.

158. Singhal GD, Sharma KR. Ophthalmic \&

Otorhinolaryngological Considerations in Ancient Indian Surgery: Based on Salakya-Tantra Portion of UttaraTantra of Susruta Samhita. Varanasi: Banaras Hindu University, 1976:200-2.

159. Roy PN, Mehra KS, Deshpande PJ. Cataract surgery performed before 800 BC. Br J Ophthalmol 1975;59:171. 
160. Grzybowski A, Ascaso FJ. Sushruta in 600 B.C. introduced extraocular expulsion of lens material. Acta Ophthalmol 2014;92:194-7.

161. Mukhopādhyaya G. The surgical Instruments of the Hindus with a comparative study of the surgical instruments of the Greek, Roman, Arab and the modern European surgeons. Vol. 1. Calcutta: Calcutta Univ, 1913:275.

162.Feigenbaum A. Early history of cataract and the ancient operation for cataract. Am J Ophthalmol 1960;49:305-26.

163. Dutt KC. Cataract operations in the prehistoric age. Arch Ophthalmol 1938;20:1-15.

164. Shah TM. Summary of a few surgical operations as performed by Hakeems. Med Rep 1894;3:311-2.

165. Scott H. Some remarks on the arts of India, with miscellaneous observations on various subjects. J Sci Art 1817;2:67-71.

166. Bogle G, Hamilton A, Lamb A. 2002. Bhutan and Tibet: the Travels of George Bogle and Alexander Hamilton 1774-1777; vol. 1, Letters, Journals, and Memoranda. Hertingfordbury: Roxford Books, 2002:389.

167. Singer J. Blindness and Therapy in Late Medieval French and Italian Poetry. Cambridge: Brewer, 2011:137-46.

168. Brandt F, Hennig A, Prasad LN, et al. Ergebnisse der operative Reklination der Linse (Eine Studie aus Nepal).

Klin Mbl Augenheilkd 1984;185:543-6.

169. Pridmore WG. Is Cataract Couching Ever Justifiable? Ind Med Gaz 1905;40:320.

170.Es-Sa'di, Houdas O (trans.). Tarikh es-Soudan par Abderrahman ben Abdallah ben 'Imran ben 'Amir esSa'di. Traduit de l'Arabe par O. Houdas. Paris: Leroux, 1909:445-6.

171.al-Tunisi M, Davies H (trans.). In Darfur: An Account of the Sultanate and Its People, Volume Two. New York: New York University Press, 2018:171.

172. Garap JN, Sheeladevi S, Brian G, et al. Cataract and its surgery in Papua New Guinea. Clin Exp Ophthalmol 2006;34:880-5.

173.Leffler CT, Schwartz SG. A Family of Early English

Cite this article as: Leffler CT, Klebanov A, Samara WA, Grzybowski A. The history of cataract surgery: from couching to phacoemulsification. Ann Transl Med 2020;8(22):1551. doi: 10.21037/atm-2019-rcs-04
Oculists (1600-1751), With a Reappraisal of John Thomas Woolhouse (1664-1733/1734). Ophthalmol Eye Dis 2017;9:1179172117732042.

174. Hope T. Extracts of two letters of Thomas Hope, MD to John Clephane, MD FRS concerning Monsieur Daviel's method of couching a cataract. Phil Trans Royal Soc London 1752;47:530-3.

175. Cleland A. A description of needles made for operations on the eyes, and of some instruments for the ears, by the same. Phil Trans Royal Soc London 1741;41-2:847-51.

176.Leffler CT, Letocha CE, Pierson K, et al. Aspiration of cataract in 1815 in Philadelphia, Pennsylvania. Digit J Ophthalmol 2017;23:4-7.

177.Panas P. Asepsis and prophylaxis in ophthalmology. Am J Ophthalmol 1903;XX:72-89.

178.Hirschberg J, Blodi FC (trans.). The History of Ophthalmology. Vol. 11, Part 1-b. The Reform of Ophthalmology. Bonn: Wayenborgh, 1992:52.

179.Jaffe NS. History of cataract surgery. Ophthalmology 1996;103:S5-16.

180. Grzybowski A, Kanclerz P. Tadeusz Krwawicz, MD: The inventor of cryosurgery in ophthalmology. Eur J Ophthalmol 2019;29:348-56.

181. Troutman RC. The operating microscope in ophthalmic surgery. Trans Am Ophthalmol Soc 1965;63:335.

182. Kelman CD. Phaco-emulsification and aspiration: a new technique of cataract removal: a preliminary report. Am J Ophthalmol 1967;64:23-35.

183. Stark WJ, Worthen DM, Holladay JT, et al. The FDA report on intraocular lenses. Ophthalmology 1983;90:311-7.

184.Vāgbhata, Srikantha Murthy KR (trans.) Vāgbhața's Aștāñga Hṛdayam. Vol. III (Uttara Sthana). Varanasi: Chowkhamba Press, 2017:133.

185. Digital Corpus of Sanskrit. Așțāngahṛdayasaṃhitā (AHS, Utt, 14, 15.2). Accessed January 9, 2020. Available online: http://www.sanskrit-linguistics.org/dcs/index.php?content $\mathrm{s}=$ texte $\&$ PhraseID $=38580$ 